\title{
Article \\ A Comprehensive Analysis of the Metal-Nitrile Bonding in an Organo-Diiron System
}

\author{
Giulio Bresciani ${ }^{1,2}{ }^{\oplus}$, Lorenzo Biancalana ${ }^{1,2}$, Guido Pampaloni ${ }^{1,2}{ }^{(D}$, Stefano Zacchini ${ }^{2,3}{ }^{(0)}$, \\ Gianluca Ciancaleoni $1,2, *$ (D) and Fabio Marchetti $1,2, *$ (D) \\ 1 Department of Chemistry and Industrial Chemistry, University of Pisa, Via G. Moruzzi 13, I-56124 Pisa, Italy; \\ giulio.bresciani@dcci.unipi.it (G.B.); lorenzo.biancalana@unipi.it (L.B.); guido.pampaloni@unipi.it (G.P.) \\ 2 Interuniversity Consortium for Chemical Reactivity and Catalysis (CIRCC), Via Celso Ulpiani 27, \\ I-70126 Bari, Italy; stefano.zacchini@unibo.it \\ 3 Department of Industrial Chemistry "Toso Montanari", University of Bologna, Viale Risorgimento 4, \\ I-40136 Bologna, Italy \\ * Correspondence: gianluca.ciancaleoni@unipi.it (G.C.); fabio.marchetti1974@unipi.it (F.M.)
}

Citation: Bresciani, G.; Biancalana,

L.; Pampaloni, G.; Zacchini, S.;

Ciancaleoni, G.; Marchetti, F. A

Comprehensive Analysis of the Metal-Nitrile Bonding in an Organo-Diiron System. Molecules 2021, 26, 7088. https://doi.org/ $10.3390 /$ molecules 26237088

Academic Editor: Michal Szostak

Received: 4 November 2021

Accepted: 19 November 2021

Published: 23 November 2021

Publisher's Note: MDPI stays neutral with regard to jurisdictional claims in published maps and institutional affiliations.

Copyright: (c) 2021 by the authors. Licensee MDPI, Basel, Switzerland. This article is an open access article distributed under the terms and conditions of the Creative Commons Attribution (CC BY) license (https:/ / creativecommons.org/licenses/by/ $4.0 /)$.

\begin{abstract}
Nitriles $(\mathrm{N} \equiv \mathrm{CR})$ are ubiquitous in coordination chemistry, yet literature studies on metalnitrile bonding based on a multi-technique approach are rare. We selected an easily-available diorganoiron framework, containing both $\pi$-acceptor $\left(\mathrm{CO}\right.$, aminocarbyne) and donor $\left(\mathrm{Cp}=\eta^{5}-\mathrm{C}_{5} \mathrm{H}_{5}\right)$ ligands, as a suitable system to provide a comprehensive description of the iron-nitrile bond. Thus, the new nitrile (2-12) $\mathrm{CF}_{3} \mathrm{SO}_{3}$ and the related imine/amine complexes (8-9) $\mathrm{CF}_{3} \mathrm{SO}_{3}$ were synthesized in $58-83 \%$ yields from the respective tris-carbonyl precursors (1a-d) $\mathrm{CF}_{3} \mathrm{SO}_{3}$, using the TMNO strategy (TMNO = trimethylamine-N-oxide). The products were fully characterized by elemental analysis, IR (solution and solid state) and multinuclear NMR spectroscopy. In addition, the structures

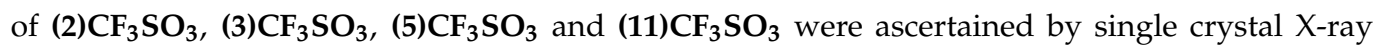
diffraction. Salient spectroscopic data of the nitrile complexes are coherent with the scale of electrondonor power of the R substituents; otherwise, this scale does not match the degree of $\mathrm{Fe} \rightarrow \mathrm{N} \pi$-backdonation and the $\mathrm{Fe}-\mathrm{N}$ bond energies, which were elucidated in (2-7) $\mathrm{CF}_{3} \mathrm{SO}_{3}$ by DFT calculations.
\end{abstract}

Keywords: coordination chemistry; nitrile ligand; metal-nitrile bonding; $\pi$-back-donation; diiron complexes; DFT calculations

\section{Introduction}

Nitriles $(\mathrm{N} \equiv \mathrm{CR})$ are ubiquitous and versatile ligands in coordination chemistry [1-3]. They most commonly behave as monodentate (end-on) ligands, and have been widely employed as weakly coordinating agents in complexes of low- to middle-valent transition metals, since their substitution by more strongly coordinating ligands is a convenient strategy to access a multitude of derivatives, catalysts and materials [4-11]. Furthermore, nitrile ligands are usually susceptible to nucleophilic attack [12-14] and may be engaged in a great variety of chemical transformations mediated by the adjacent metal centre, either catalytic [15-18] or stoichiometric [12,19-23].

In principle, the metal-nitrile bond can be described in terms of four resonance structures (Scheme 1).

Structure $\mathbf{A}$ accounts for a purely electrostatic interaction: the metal attracts the nitrile electrons (both $\sigma$ and $\pi$ ), thus strengthening the triple $\mathrm{N} \equiv \mathrm{C}$ bond with a polarization toward the nitrogen $(\mathrm{N} \leftarrow \mathrm{C})$. Structure $\mathbf{B}$ represents the $\sigma$ metal-nitrile bond, where the polarization is still $\mathrm{N} \leftarrow \mathrm{C}$ (bond strengthening) because of the formal charge on the nitrogen. Structure $\mathbf{C}$ shows the back-donation of an electron pair from the metal to one $\pi^{*}$ orbital of the nitrile. In this case, the polarization is $N \rightarrow C$ and thus the $N \equiv C$ bond is weakened. As two empty $\pi^{*}$ orbitals are available on the nitrile, the metal may back-donate 
an additional electron pair, leading to the limit structure $\mathbf{D}$, wherein the $\mathrm{N} \rightarrow \mathrm{C}$ polarization and the carbon-nitrogen bond weakening reach their extreme.

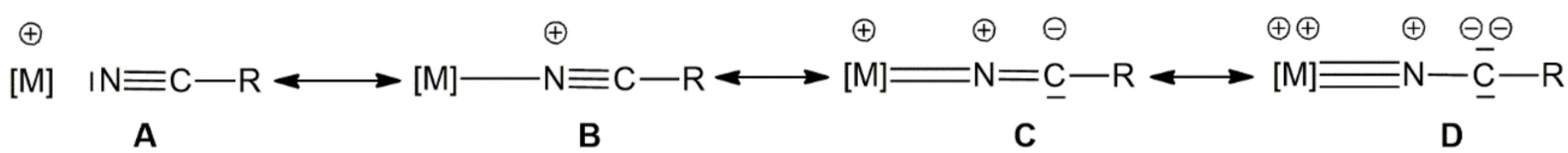

Scheme 1. Resonance structures contributing to a generic metal-nitrile bond.

In most literature cases, end-on nitriles have been regarded as essentially $\sigma$-donor ligands, with a possible secondary contribution to the bond with the metal arising from $\pi$-back-donation $[1,24,25]$. Pombeiro placed nitriles and phosphines approximately on the same level of a scale of net $\pi$-electron acceptor minus $\sigma$-donor character, based on electrochemical studies [26-28].

In several cases, IR data have been invoked to proof the occurrence of metal to nitrile $\pi$-back-donation. While the stretching wavenumber of the $\mathrm{N} \equiv \mathrm{C}$ bond $\left(\tilde{v}_{\mathrm{N}} \equiv \mathrm{C}\right)$ is often quite near to that of the uncoordinated nitrile, or even higher [29], a wavenumber decrease upon coordination has been imputed to $\pi$-back-donation. This feature was prevalently observed with arylnitriles [24,30-32], and less frequently with acetonitrile, cyanoacetic acid $\left(\mathrm{N} \equiv \mathrm{CCH}_{2} \mathrm{CO}_{2} \mathrm{H}\right)$ and acrylonitrile $\left(\mathrm{N} \equiv \mathrm{CCH}=\mathrm{CH}_{2}\right)$ [33]. For instance, Skelton and co-workers prepared a series of mono- and bis-nitrile iron derivatives (Figure 1, structure I) [34], and observed a minor change of $\tilde{\cup}_{\mathrm{N} \equiv \mathrm{C}}\left(\mathrm{N} \equiv \mathrm{CCH}_{3}\right.$ ligand) with respect to free acetonitrile, whereas a decrease by $10-30 \mathrm{~cm}^{-1}$ was recognized with aryl-nitriles. In addition, the $\mathrm{X}$-ray structures displayed a shorter Fe-N distance in $\left[\mathrm{Fe}(\mathrm{DMPE})_{2}\left\{\mathrm{NC}\left(4-\mathrm{C}_{6} \mathrm{H}_{4} \mathrm{Br}\right)\right\}_{2}\right]^{2+}[1.893(7) \AA]$ than in $\left[\mathrm{Fe}(\mathrm{DMPE})_{2}\{\mathrm{NCPh}\}_{2}\right]^{2+}[1.917(5) \AA]$ (DMPE $=1,2$-bis(dimethylphosphino)ethane), attributed to a higher degree of back-donation in the former, due to the electron-withdrawing effect of the Br-substituent. Conversely, $\mathrm{X}$-ray data related to a series of $\left[\mathrm{RuCl}(\mathrm{NCR})(\mathrm{DPPM})_{2}\right]^{+} \mathrm{com}-$ plexes (DPPM $=\mathrm{Ph}_{2} \mathrm{PCH}_{2} \mathrm{PPh}_{2}$ ) with alkyl-nitriles revealed almost identical distances for the Ru-P bonds - trans to the chloride and trans to the nitrile, respectively-thus arguing against any significant $\mathrm{Ru}$ to NCR $\pi$-back-donation [35].
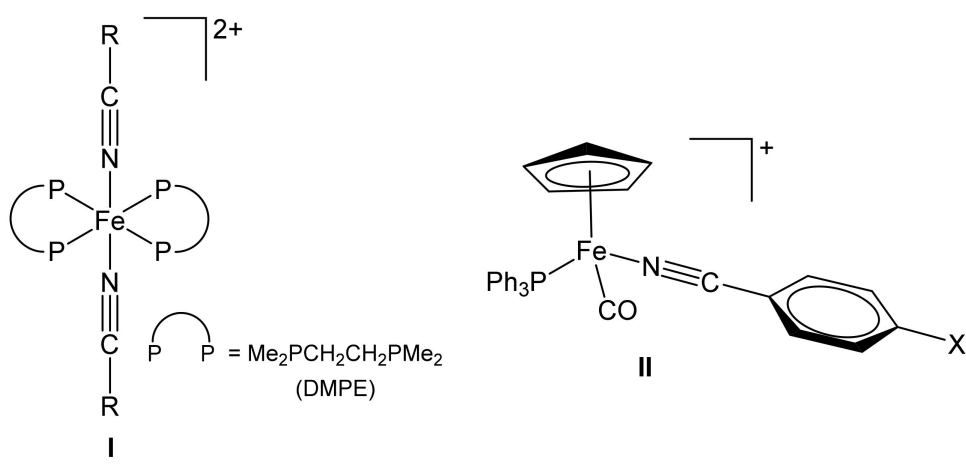

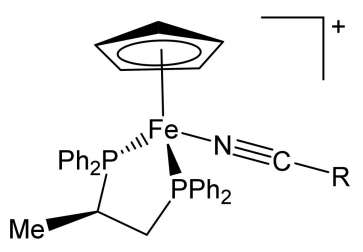

III

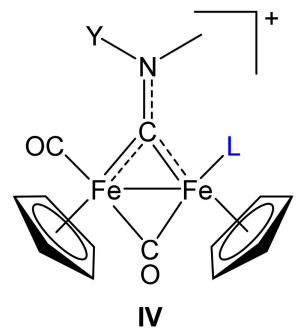

Figure 1. Iron-nitrile complexes cited in the Introduction. (I) $\mathrm{R}=\mathrm{Me}, \mathrm{Ph}, 4-\mathrm{C}_{6} \mathrm{H}_{4} \mathrm{Br}$ [13]. (II) $\mathrm{X}=\mathrm{H}, \mathrm{OH}, \mathrm{CH}_{2} \mathrm{OH}, \mathrm{NH}_{2}, \mathrm{Br}, \mathrm{Cl}$ [15]. (III) $\mathrm{R}=\mathrm{Et}, \mathrm{Ph}, 4-\mathrm{C}_{6} \mathrm{H}_{4} \mathrm{Me}, 4-\mathrm{C}_{6} \mathrm{H}_{4} \mathrm{OMe}, 4-\mathrm{C}_{6} \mathrm{H}_{4} \mathrm{NMe}_{2}$, $4-\mathrm{C}_{6} \mathrm{H}_{4} \mathrm{NO}_{2}$ [16]. (IV) Diiron complexes with a bridging aminocarbyne ligand ( $\mathrm{Y}=$ alkyl or aryl; $\mathrm{L}=\mathrm{CO}$, replaceable with a nitrile). 
Piano-stool iron complexes of the type $\left[\mathrm{FeCp}(\mathrm{CO})\left\{\mathrm{NC}\left(4-\mathrm{C}_{6} \mathrm{H}_{4} \mathrm{X}\right)\right\}\left(\mathrm{PPh}_{3}\right)\right]^{+}$(Figure 1, structure II) manifested electronic effects (IR and NMR data) related to the aryl substituent $(\mathrm{X})$, which were tentatively explained with an increase of Fe to $\mathrm{N}$ back-donation on going along the series $\mathrm{X}=\mathrm{OH}<\mathrm{H}<\mathrm{Br}[36]$.

The effect of the nitrile substituent $(\mathrm{R})$ on the strength of the metal-nitrile bond was elegantly demonstrated on the series of complexes [FeCp(Prophos)(NCR)]PF 6 (Figure 1, structure III); Prophos = (R)-(+)-1,2-bis(diphenylphosphino)propane), by means of a kinetic study in $\mathrm{CDCl}_{3}$ solution [37]. These complexes contain two chiral centres, and the ratedetermining step for the first-order epimerization reaction is the cleavage of the iron-nitrile bond. Therefore, the following sequence of stability was established on account of the halflife times of complexes; i.e., NCMe $<\mathrm{NCEt}<\mathrm{NCPh}<\mathrm{NC}\left(4-\mathrm{C}_{6} \mathrm{H}_{4} \mathrm{Me}\right)<\mathrm{NC}\left(4-\mathrm{C}_{6} \mathrm{H}_{4} \mathrm{NMe}_{2}\right)$.

Casarin and co-workers estimated the $\pi$-backbonding in $\left[\mathrm{PtCl}_{2}(\mathrm{NCR})_{2}\right]$ adducts as $30-40 \%$ of the total $\mathrm{Pt}-\mathrm{N}$ bonding interaction, and pointed out the negligible effect of the $\mathrm{R}$ group; these authors concluded that $\tilde{\mathrm{V}}_{\mathrm{N} \equiv \mathrm{C}}$ values are not correlated with the strength of the nitrile bond [38]. Back-donation was investigated by DFT also on other metal-nitrile systems [27,39-41].

In this scenario, a comprehensive description of metal-nitrile bonding, embracing crystallographic, spectroscopic and computational methods, is scarcely available. Our long experience with the chemistry of diiron $\mu$-aminocarbyne complexes (Figure 1, structure IV) [42-44] prompted us to exploit such a versatile and easily-accessible molecular framework to elucidate the iron-nitrile bonding picture [4]. With this purpose in mind, the considered system offers some advantageous features: (1) the effectiveness of the nitrile substituent is suggested by previous findings, according to which the $\mathrm{N} \equiv \mathrm{CR}$ ligand undergoes addition by anionic nucleophiles [45-47], leading to different outcomes depending on R [46-48]; (2) the presence of two types of $\pi$-acceptor co-ligands, i.e., the carbonyls and one (variable) aminocarbyne, amplifies the possibility of evaluating the electronic influence of $R$; (3) in principle, the formal $+\mathrm{I}$ oxidation state of the iron centres might enable an appreciable iron to nitrile back-donation despite the net cationic charge of the complex.

Trends of experimental data from our multi-technique approach will be examined in detail; we will discuss their correlation with the electronic properties of the nitrile substituents and with the degree of $\pi$-back-donation and the Fe-N bond energies, which have been estimated by DFT in the distinct cases.

\section{Results and Discussion}

\subsection{Synthesis of Diiron $\mu$-Aminocarbyne Complexes with Nitrile- and Other Nitrogen-Ligands}

The triflate salt $\left[\mathrm{Fe}_{2} \mathrm{Cp}_{2}(\mathrm{CO})_{2}(\mu-\mathrm{CO})\{\mu-\mathrm{CN}(\mathrm{Me})(\mathrm{Cy})\}\right] \mathrm{CF}_{3} \mathrm{SO}_{3}\left((\mathbf{1 a}) \mathrm{CF}_{3} \mathrm{SO}_{3}\right)[43]$ was selected as a starting material, bearing in mind that two aminocarbyne substituents of considerably different size (i.e., methyl and $\mathrm{Cy}=$ cyclohexyl) could supply information about steric factors related to nitrile coordination. More precisely, the aminocarbyne group possesses some iminium character, whereby the rotation around the carbyne-nitrogen bond is inhibited at room temperature; therefore, the replacement of one $\mathrm{CO}$ with a nitrile ligand may result in the formation of two isomers with a ratio depending on the relative hindrance of nitrile and $\mathrm{Y}$ (Figure 2), vide infra. The novel complexes (2-7) $\mathrm{CF}_{3} \mathrm{SO}_{3}$ were prepared from the reactions of $(1 \mathrm{a}) \mathrm{CF}_{3} \mathrm{SO}_{3}$ with the appropriate nitrile reactant, in the presence of a slight excess of $\mathrm{Me}_{3} \mathrm{NO} \cdot 2 \mathrm{H}_{2} \mathrm{O}$ (Scheme 2). The products were purified by alumina chromatography and finally isolated as air-stable solids in $69-83 \%$ yields. By using a similar procedure, the new complexes $(8) \mathrm{CF}_{3} \mathrm{SO}_{3}$ and ${ }^{(9)} \mathrm{CF}_{3} \mathrm{SO}_{3}$, containing respectively an imine and an amine as monodentate $\mathrm{N}$-donor ligands, were also synthesized for comparative purposes (58-62\% yields, Scheme 2). Moreover, in order to evaluate the possible effect of the aminocarbyne substituents on iron-nitrile bonding, complexes (10-12) $\mathrm{CF}_{3} \mathrm{SO}_{3}$ were obtained from the respective tris-carbonyl precursors, $\left(\mathbf{( b - d )} \mathbf{C F}_{3} \mathbf{S O}_{3}\right.$, in $64-77 \%$ yields (Scheme 3). 


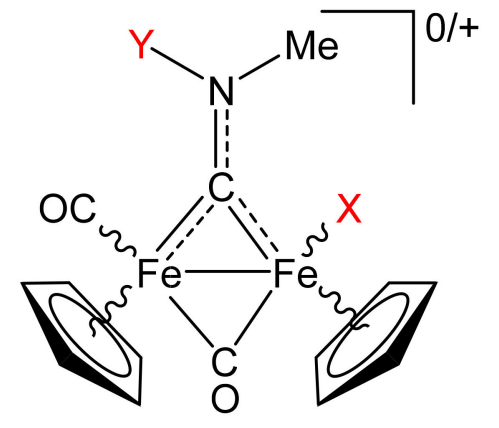

$\alpha(\mathrm{E})$

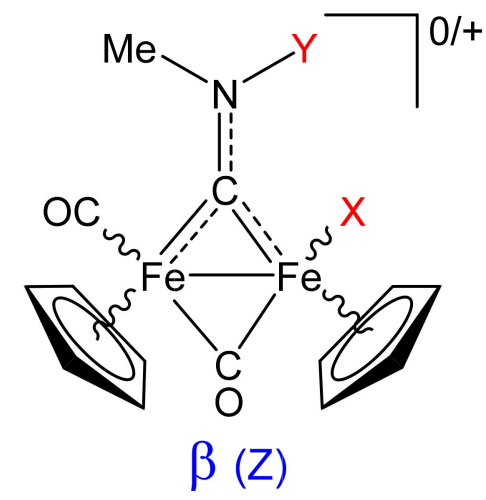

Figure 2. Isomerism in asymmetric diiron $\mu$-aminocarbyne complexes ( $\mathrm{Cp}$ rings in cis or trans position). $\mathrm{Y}=\mathrm{CH}_{2} \mathrm{Ph}$ or $2,6-\mathrm{C}_{6} \mathrm{H}_{3} \mathrm{Me}_{2} . \mathrm{X}=\mathrm{Ph}$, alkyl, dithiocarbamate, halide/pseudohalide (neutral complexes); $\mathrm{X}=$ nitrile, isocyanide, phosphine, imine, carbene (cationic complexes). When $\mathrm{X}=$ nitrile, $\alpha$ and $\beta$ correspond to $\mathrm{E}$ and $\mathrm{Z}$ isomers, respectively.

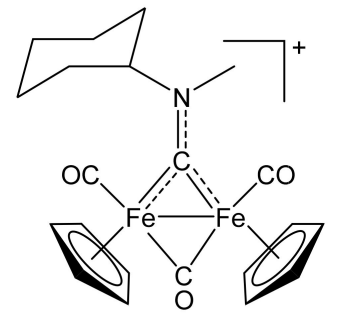

$[1 \mathrm{a}]^{+}$

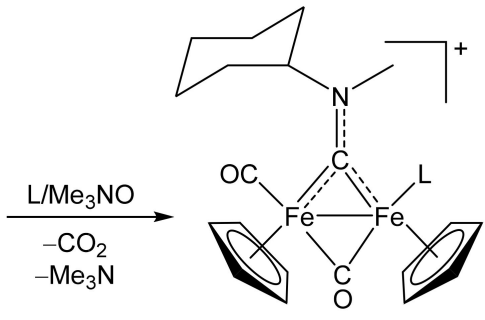

L

$2]^{+} \mathrm{NCMe}$

$[3]^{+} \mathrm{NCCMe}_{3}$

$[4]^{+} \mathrm{NCPh}$

$[5]^{+} \mathrm{NC}\left(4-\mathrm{C}_{6} \mathrm{H}_{4} \mathrm{NMe}_{2}\right)$

$[6]^{+} \mathrm{NC}\left(4-\mathrm{C}_{6} \mathrm{H}_{4} \mathrm{NO}_{2}\right)$

$[7]^{+} \mathrm{NC}\left(4-\mathrm{C}_{6} \mathrm{H}_{4} \mathrm{~F}\right)$

$[8]^{+} \mathrm{HN}=\mathrm{CPh}_{2}$

[9] ${ }^{+} \mathrm{NH}_{2} \mathrm{Et}$

Scheme 2. Carbonyl-substitution reactions on a ( $N$-methyl, $N$-cyclohexyl)aminocarbyne diiron complex $\left(\mathrm{CF}_{3} \mathrm{SO}_{3}{ }^{-}\right.$salts $)$.
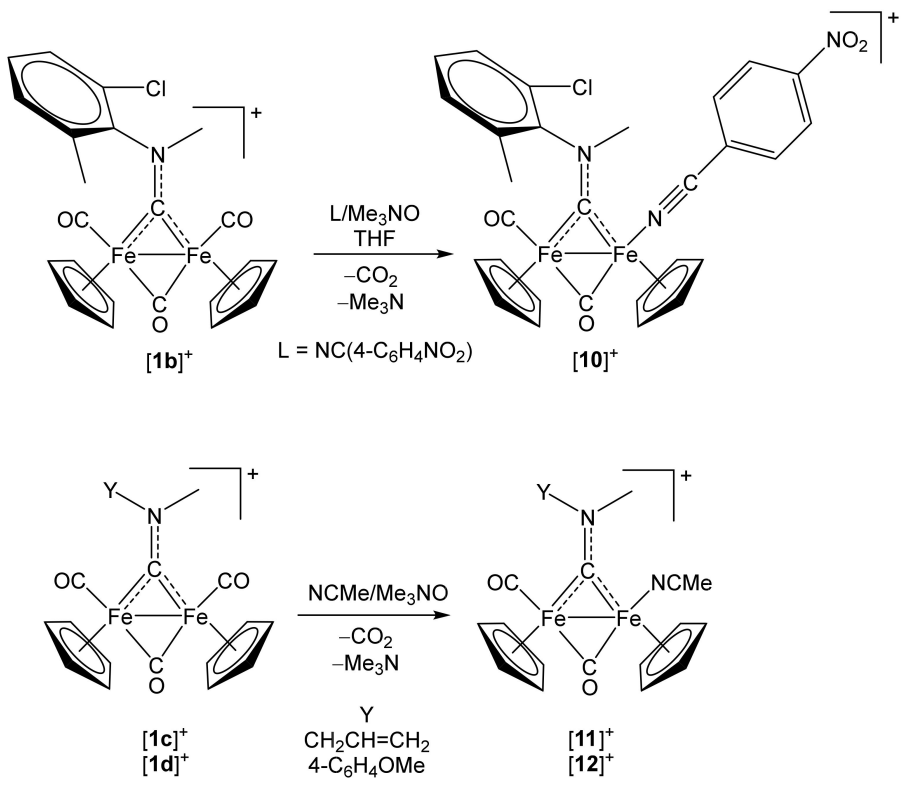

Scheme 3. Synthesis of nitrile derivatives from complexes with different aminocarbyne substituents $\left(\mathrm{CF}_{3} \mathrm{SO}_{3}{ }^{-}\right.$salts). 
All the products were fully characterized by means of elemental analysis, IR, ${ }^{1} \mathrm{H}$ and ${ }^{13} \mathrm{C}$ NMR spectroscopy (Figures S1-S47): the salient spectroscopic features are visualized in Table 1. In addition, the structures of $(2) \mathrm{CF}_{3} \mathrm{SO}_{3},(3) \mathrm{CF}_{3} \mathrm{SO}_{3},(5) \mathrm{CF}_{3} \mathrm{SO}_{3}$ and ${ }^{(11)} \mathrm{CF}_{3} \mathrm{SO}_{3}$ were ascertained by single crystal $\mathrm{X}$-ray diffraction studies, and nitrile complexes (2-7) $\mathrm{CF}_{3} \mathrm{SO}_{3}$ underwent DFT investigation. Spectroscopic, $X$-ray and DFT data will be discussed in the following sections.

Table 1. Comparative view of IR and NMR data for complexes (2-12) $\mathrm{CF}_{3} \mathrm{SO}_{3}$. $\Delta \tilde{u}(\mathrm{~N} \equiv \mathrm{C})=\tilde{u}($ complex)- $\tilde{u}($ uncoordinated nitrile [49]). $\Delta \delta(\mathrm{N} \equiv \mathrm{C})=\delta$ (complex)- $\delta$ (uncoordinated nitrile [50]). ${ }^{\mathrm{a}} \mathrm{E}$ isomer. ${ }^{\mathrm{b}} \mathrm{Z}$ isomer. ${ }^{\mathrm{c}}$ Average value.

\begin{tabular}{|c|c|c|c|c|c|c|c|c|c|c|c|c|c|c|}
\hline \multirow[b]{2}{*}{ Comp. } & \multicolumn{5}{|c|}{ IR $\left(\mathrm{CH}_{2} \mathrm{Cl}_{2}\right), \widetilde{\circlearrowleft} / \mathrm{cm}^{-1}$} & \multicolumn{2}{|c|}{ IR (Solid), $\widetilde{O} / \mathrm{cm}^{-1}$} & \multicolumn{6}{|c|}{${ }^{13}$ C NMR (Acetone- $\mathrm{d}_{6}$ ), $\delta / p p m$} & \multirow[t]{2}{*}{ E/Z. Ratio } \\
\hline & $\tilde{v}(\mathrm{t}-\mathrm{CO})$ & $\tilde{\sigma}(\mu-\mathrm{CO})$ & $\tilde{\sigma}(\mu-\mathrm{CN})$ & $\stackrel{\tilde{\sigma}}{(\mathrm{N} \equiv \mathrm{C})}$ & $\begin{array}{c}\Delta \tilde{\sigma} \\
(\mathrm{N} \equiv \mathrm{C})\end{array}$ & $(\mathrm{N} \equiv \mathrm{C})$ & $\begin{array}{c}\Delta \widetilde{\sigma} \\
(\mathbf{N} \equiv \mathbf{C})\end{array}$ & $\delta(\mu-\mathrm{CN})^{\mathrm{a}}$ & $\delta(\mu-\mathrm{CN}){ }^{b}$ & $\delta(\mathrm{N} \equiv \mathrm{C})^{\mathrm{a}}$ & $\delta(N \equiv C)^{b}$ & $\Delta \delta(N \equiv C)^{a}$ & $\Delta \delta(N \equiv C) b$ & \\
\hline$(2)^{+}$ & 1985 & 1818 & 1561 & 2279 & +25 & 2279 & +26 & 330.5 & & 132.0 & 131.8 & +14.6 & +14.4 & 1.9 \\
\hline$(3)^{+}$ & 1984 & 1820 & 1559 & 2264 & +31 & 2262 & +27 & 330.7 & 330.2 & 139.8 & 140.0 & +13.1 & +13.3 & 2.3 \\
\hline$(4)^{+}$ & 1984 & 1820 & 1560 & 2238 & +8 & 2238 & +9 & 329.7 & 330.0 & 131.2 & 131.6 & +11.9 & +12.3 & 1.2 \\
\hline$(5)^{+}$ & 1985 & 1819 & 1561 & 2227 & +12 & 2227 & +17 & 330.9 & 330.4 & 133.4 & 133.9 & +12.4 & +12.9 & 1.1 \\
\hline$(6)^{+}$ & 1982 & 1821 & 1561 & 2230 & -7 & 2230 & -3 & 329.2 & 329.0 & 129.2 & 129.6 & +11.4 & +11.8 & 1.3 \\
\hline$(7)^{+}$ & 1983 & 1819 & 1559 & 2240 & +7 & 2240 & +6 & 329.9 & 329.7 & 130.4 & 130.7 & +11.8 & +12.1 & 1.0 \\
\hline$(8)^{+}$ & 1974 & 1810 & 1558 & & & & & 334.5 & & & & & & 1.7 \\
\hline$(9)^{+}$ & 1965 & 1800 & 1532 & & & & & 331.7 & 332.0 & & & & & 1.3 \\
\hline$(10)^{+}$ & 1984 & 1820 & 1560 & 2235 & -2 & 2235 & +2 & $342.0^{\mathrm{C}}$ & $341.1^{\mathrm{C}}$ & $129.1^{\mathrm{c}}$ & $130.0^{\mathrm{c}}$ & $+11.3^{\mathrm{c}}$ & $+12.2^{\mathrm{C}}$ & 2.3 \\
\hline$(11)^{+}$ & 1987 & 1818 & 1568 & 2277 & +23 & 2277 & +24 & & 333.4 & & 132.1 & & +14.7 & 0.15 \\
\hline$(12)^{+}$ & 1984 & 1817 & 1525 & 2281 & +27 & 2281 & +28 & 338.2 & 338.1 & 132.1 & 132.3 & +14.7 & +14.9 & 0.82 \\
\hline
\end{tabular}

\subsection{Analysis of IR Spectra}

IR spectra were recorded both in dichloromethane solution and in the solid state. They share a common pattern consisting of three main absorptions in the $2300-1500 \mathrm{~cm}^{-1}$ region, ascribable to the terminal and bridging carbonyls and the carbyne-nitrogen bond; isomers (see Section 3) are not distinguishable. Data indicate that the $\mu-(\mathrm{C}-\mathrm{N})$ bond possesses some double bond character (iminium character), as usually found in related compounds (Scheme 4) $[42,51,52]$. The nature of the nitrile has negligible influence on the CO, $\mu$-CO and $\mu-\mathrm{CN}$ stretching vibrations which, for compounds $(2-7) \mathrm{CF}_{3} \mathrm{SO}_{3}$, fall within the narrow intervals 1982-1985, 1818-1821 and 1559-1561 cm ${ }^{-1}$, respectively (in $\mathrm{CH}_{2} \mathrm{Cl}_{2}$ ). Complexes $(8,9) \mathrm{CF}_{3} \mathrm{SO}_{3}$ display significantly lower values for the $\mathrm{CO}$ wavenumbers, thus pointing out the stronger electron-donor power of ethylamine and, to a less extent, benzophenone imine with respect to the investigated nitriles. The relatively high electron donation supplied by $\mathrm{NH}_{2}$ Et also enhances the metal-to-carbyne back-donation (Scheme 4, resonance structures $\mathbf{R} 1$ and R2) with consequent weakening of the $\mu-C-N$ bond $\left(\tilde{v}=1532 \mathrm{~cm}^{-1}\right)$.

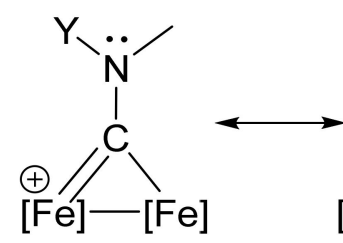

R1<smiles>[Y]N(C)C1=[Te]C2[Te]C12[I-]</smiles>

R2<smiles>[Y]N(C)C1=[In]C1[I-]</smiles>

R3

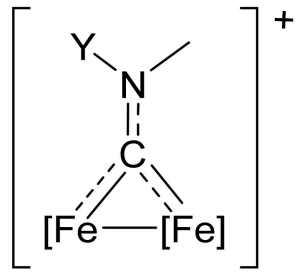

Scheme 4. Resonance structures representing the aminocarbyne (R1, R2) and iminium (R3) character of the bridging hydrocarbyl ligand in $(\mathbf{2 - 1 2})^{+}$, and combined representation with delocalized charge.

The nitrile $\mathrm{N} \equiv \mathrm{C}$ stretching gives rise to a weak absorption in the $2230-2280 \mathrm{~cm}^{-1}$ region. The variations of wavenumber $(\Delta \tilde{\mathrm{u}})$ of the nitrile stretching in the complexes with respect to the corresponding uncoordinated nitriles are compiled in Table 1, with reference to both dichloromethane solutions and solid state. $\Delta \tilde{u}$ values decrease along the series $(3)^{+}>(2)^{+}>(5)^{+}>(4)^{+}>(7)^{+}>(6)^{+}$, in accordance with the progressive decrease of the electron-donor ability of the $R$ substituent 
( ${ }^{\mathrm{t}} \mathrm{Bu}>\mathrm{Me}>4-\mathrm{C}_{6} \mathrm{H}_{4} \mathrm{NMe}_{2}>\mathrm{C}_{6} \mathrm{H}_{5}>4-\mathrm{C}_{6} \mathrm{H}_{4} \mathrm{~F}>4-\mathrm{C}_{6} \mathrm{H}_{4} \mathrm{NO}_{2}$ ), and are all slightly positive except for the 4-nitrobenzonitrile complexes $(6)^{+}$and $(10)^{+}$. Moreover, $\Delta \tilde{u}$ for the acetonitrile complexes varies according to the sequence $(\mathbf{1 2})^{+}>(\mathbf{2})^{+}>(\mathbf{1 1})^{+}$, suggesting that the $\pi$-acceptor potential of NCMe ligand is affected by the aminocarbyne substituents, and decreases along the series $\mathrm{Y}=$ allyl $>$ cyclohexyl $>$ 4-methoxyphenyl. Note that the same sequence is reflected in the $\tilde{u}(\mu-\mathrm{CN})$ values $\left((\mathbf{1 2})^{+}<(\mathbf{2})^{+}<(\mathbf{1 1})^{+}\right)$.

Similarly, $\Delta \tilde{u}$ is lower in $(6)^{+}\left(\mathrm{R}=4-\mathrm{C}_{6} \mathrm{H}_{4} \mathrm{NO}_{2}, \mathrm{Y}=\mathrm{Cy}\right)$ than in $(\mathbf{1 0})^{+}\left(\mathrm{R}=4-\mathrm{C}_{6} \mathrm{H}_{4} \mathrm{NO}_{2}\right.$, $\left.\mathrm{Y}=2,6-\mathrm{C}_{6} \mathrm{H}_{3} \mathrm{MeCl}\right)$, because of the superior electron-donor character of the cyclohexyl aminocarbyne substituent compared to 2-chloro-6-methylphenyl, favouring in (6) ${ }^{+}$backdonation from the iron to 4-nitrobenzonitrile, at the expense of the aminocarbyne.

\subsection{Analysis of NMR Spectra}

As expected, the NMR spectra of (2-12) $\mathrm{CF}_{3} \mathrm{SO}_{3}$ reveal the existence in solution of E$\mathrm{Z}$ isomers, with reference to the different orientations assumed by the aminocarbyne (iminium) substituents with respect to the terminal $\mathrm{CO}$ and $\mathrm{L}$ ligands. This kind of isomerism was previously recognized in many other diiron aminocarbyne complexes of general formula $\left[\mathrm{Fe}_{2} \mathrm{Cp}_{2}(\mathrm{CO})(\mathrm{X})(\mu-\mathrm{CO})\{\mu-\mathrm{CN}(\mathrm{Me})(\mathrm{Y})\}\right]^{0 /+}(\mathrm{X}=$ anionic or neutral ligand $\neq \mathrm{CO} ; \mathrm{Y} \neq \mathrm{Me}$ ), and isomers were generally named $\alpha$ and $\beta$ (Figure 2 ); in most cases, $\mathrm{Y}$ and $\mathrm{X}$ are bulkier than $\mathrm{Me}$ and $\mathrm{CO}$, respectively, therefore the $\alpha$ form is expected to be favoured over the $\beta$ one for steric reasons $[42,45,53,54]$.

Based on cross-comparison with the NMR data from a library of compounds, (2-12) ${ }^{+}$ exhibit cis geometry of the Cp rings, and the $\mathrm{E}(\alpha)$ isomer (Y and L placed on opposite sides) is prevalent in $(2)^{+}$and $(3)^{+}$, and slightly prevalent in $(4)^{+},(5)^{+},(6)^{+},(8)^{+}$and $(9)^{+}$. On the other hand, the $\mathrm{Z}(\beta)$ isomer is major in $(\mathbf{1 1})^{+}$, and slightly prevalent in $(\mathbf{1 2})^{+}$. Looking at the ratios reported in Table 1 , it is presumable that additional factors, other than the steric hindrance of $Y$ and $X$, somehow contribute to the relative amount of $E$ and $Z$ isomers in the solution. The NMR spectra of $(\mathbf{1 0})^{+}$consist of four sets of resonances, arising from E-Z isomerism and, in addition, conformational isomerism resulting in two possible frozen orientations for the aryl substituents $(\mathrm{Cl}$ and $\mathrm{Me})$ with respect to the Fe-Fe axis [55].

The increase of the ${ }^{13} \mathrm{C}$ chemical shift affecting the nitrile carbon upon coordination $(\Delta \delta$, see Table 1) agrees with the tendency of the nitrile to donate charge to the metal $\left(\mathrm{R}=4-\mathrm{C}_{6} \mathrm{H}_{4} \mathrm{NO}_{2}<4-\mathrm{C}_{6} \mathrm{H}_{4} \mathrm{~F}<\mathrm{Ph}<4-\mathrm{C}_{6} \mathrm{H}_{4} \mathrm{NMe}_{2}<{ }^{\mathrm{t}} \mathrm{Bu}\right.$ ) and is almost identical for $\mathrm{E}$ and $\mathrm{Z}$ pairs. Coherently, $\Delta \delta$ slightly increases upon replacing the cyclohexyl on the aminocarbyne with a more electron-withdrawing group in the acetonitrile adducts $(2)^{+}(\mathrm{Y}=\mathrm{Cy})$ and $(\mathbf{1 2})^{+}$ $\left(\mathrm{Y}=4-\mathrm{C}_{6} \mathrm{H}_{4} \mathrm{OMe}\right)$; charge donation from the NCMe ligand to the iron was enhanced in $(\mathbf{1 2})^{+}$compared to $(2)^{+}$. In this framework, it is not surprising that, for aromatic substituents (complexes 4, 5, 6 and 7), $\delta\left(\mathrm{N} \equiv \mathrm{C}\right.$ ) correlates quite well with the Hammett parameter $\sigma_{\mathrm{p}}$.

The influence of the nitrile substituent on the ${ }^{13} \mathrm{C}$ NMR resonances of the carbonyl ligands is not appreciable within the series of complexes (2-7) $\mathrm{CF}_{3} \mathbf{S O}_{3}$ ( $\delta$ for terminal and bridging CO ligands occur in the ranges 212.3-213.6 ppm and 265.2-266.7 ppm, respectively). Otherwise, the collected ${ }^{13} \mathrm{C}$ data for the carbyne carbon permit a correlation with the electronic properties of the nitriles. In general, in diiron aminocarbyne complexes, the aminocarbyne centre resonates in the 305-390 ppm interval, and its chemical shift increases on increasing the [FeFe] to carbyne back-donation, which is enhanced by the electron withdrawing power of the N-substituents [56]. Here, this tendency is verifiable in the series of acetonitrile complexes $(\mathbf{2 Z})^{+},(\mathbf{1 1 Z})^{+}$and $(\mathbf{1 2 Z})^{+}[\delta=330.2(\mathrm{Y}=\mathrm{Cy}), 333.4$ (Y = allyl), $\left.338.1\left(\mathrm{Y}=4-\mathrm{C}_{6} \mathrm{H}_{4} \mathrm{OMe}\right)\right]$. Accordingly, within (2-7) ${ }^{+}$, the lowest value of carbyne chemical shift has been detected for (6) ${ }^{+}\left(\mathrm{R}=4-\mathrm{C}_{6} \mathrm{H}_{4} \mathrm{NO}_{2}, \delta=329.0-329.2 \mathrm{ppm}\right)$, corresponding to the minimum nitrile-to-iron donated charge (see also $\mathrm{C}_{\text {TOT }}$ in Table 4 ), thus resulting in less back-donation to the aminocarbyne $\{\mathrm{CNMe}(\mathrm{Cy})\}$. In summary, the strongly $\pi$-acceptor bridging aminocarbyne moiety, rather than the carbonyl ligands, is sensitive to the nitrile substituent $\mathrm{R}$, and the chemical shift of the former is informative about the electronic behaviour of the latter. 


\subsection{X-ray Diffraction Studies}

The molecular structures of $(2 \mathrm{Z}) \mathrm{CF}_{3} \mathrm{SO}_{3},(3 \mathrm{Z}) \mathrm{CF}_{3} \mathrm{SO}_{3},(5 \mathrm{Z}) \mathrm{CF}_{3} \mathrm{SO}_{3}$ and $(\mathbf{1 1 Z}) \mathrm{CF}_{3} \mathrm{SO}_{3}$ were determined by $\mathrm{X}$-ray diffraction (Figure 3 and Table 2). The cations are based on a diiron core comprising the $\mathrm{Cp}$ ligands in cis position, bridging aminocarbyne and $\mathrm{CO}$ ligands, and terminal CO and nitrile ligands. The C(3)-N(1) interaction [1.288(7)-1.297(4) $\AA$ ] displays some double-bond character, as typically found in analogous complexes [19-21,26,27,57,58], highlighting the hybrid aminocarbyne/iminium nature of the $\{\mu-\mathrm{CN}(\mathrm{Me})(\mathrm{Y})\}$ ligand (Scheme 4). In all structures, the nitrile ligand is on the same side with respect to the bulkier aminocarbyne substituent $\mathrm{Y}$ ( $\mathrm{Z}$ isomer). This configuration corresponds to the largely prevalent one, NMR-detected in the solution for $(\mathbf{1 1})^{+}$, while the opposite is true for $(\mathbf{2})^{+},(\mathbf{3})^{+}$and $(5)^{+}(\mathrm{E} / \mathrm{Z}$ ratio $>1$ in solution, see above). The bridging CO shows a marked asymmetry, with the $\mathrm{Fe}(2)-\mathrm{C}(2)$ interaction [1.887(6)-1.914(4) $\AA$ ] considerably shorter than $\mathrm{Fe}(1)-\mathrm{C}(2)$ $[1.947(4)-1.969(6) \AA]$. This is in keeping with the fact that $\mathrm{Fe}(2)$ is bonded to a better $\sigma$ donor ligand (the nitrile) than $\mathrm{Fe}(1)$. The iron-nitrile distances are perceptibly different in $(3 Z)^{+}[1.928(3) \AA]$ and $(5 Z)^{+}[1.912(3) \AA]$, indicating that 4-dimethylaminobenzonitrile forms a stronger bond with iron than tert-butyl-nitrile $\left((3 Z)^{+}\right)$, a feature confirmed by DFT calculations (vide infra). Regarding the nitrile ligand, the $\mathrm{N} \equiv \mathrm{C}$ distances and the $\mathrm{N}-\mathrm{C}-\mathrm{C}$ angles do not significantly differ in the four complexes.
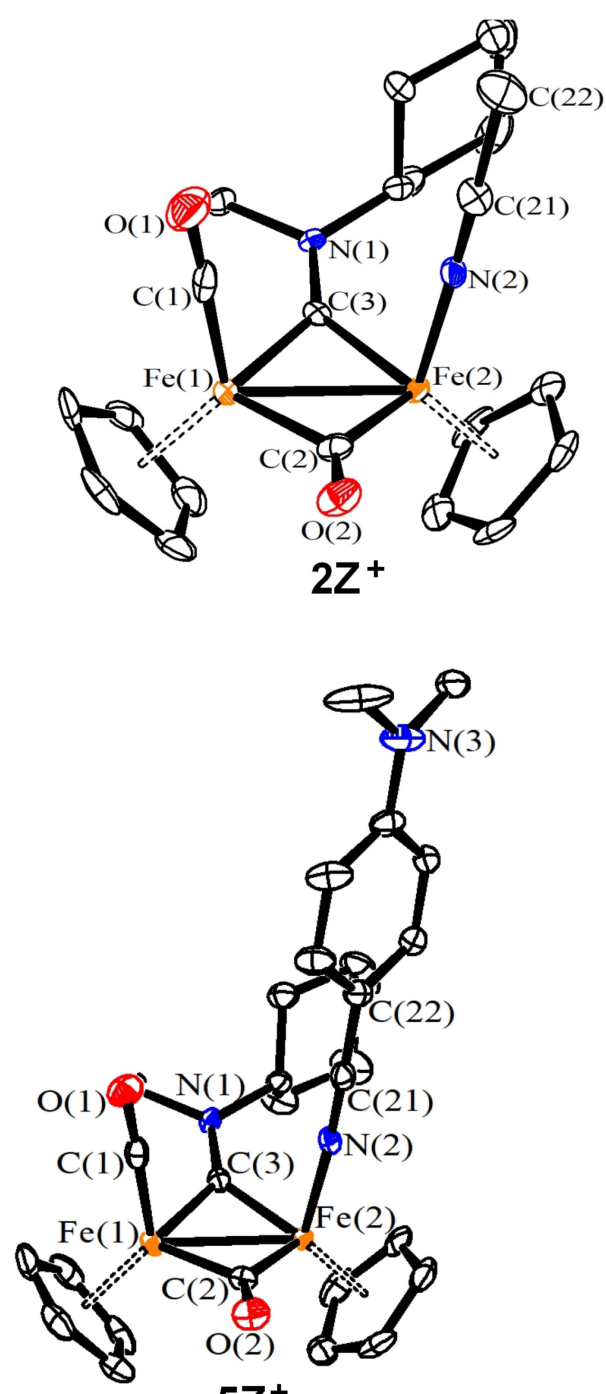

$5 Z^{+}$
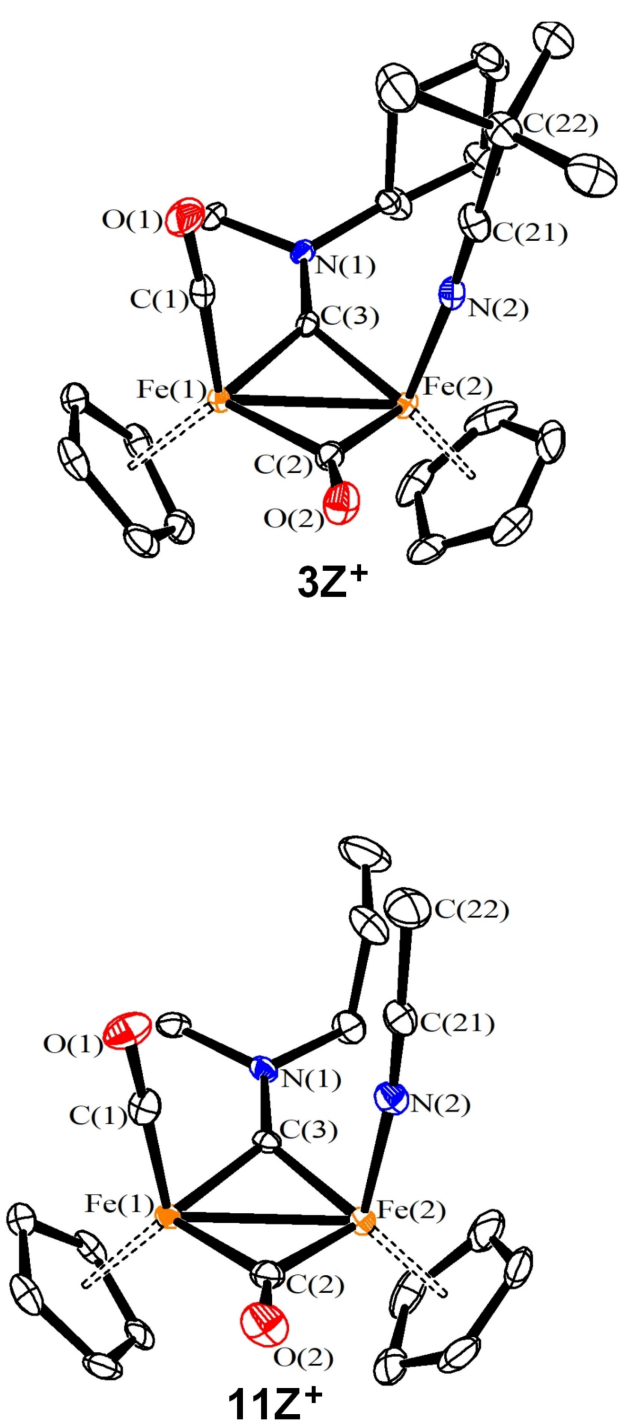

Figure 3. View of the molecular structures of the cations of $[2 \mathrm{Z}] \mathrm{CF}_{3} \mathrm{SO}_{3},[3 \mathrm{Z}] \mathrm{CF}_{3} \mathrm{SO}_{3},[5 \mathrm{Z}] \mathrm{CF}_{3} \mathrm{SO}_{3}$ and $[11 \mathrm{Z}] \mathrm{CF}_{3} \mathrm{SO}_{3}$. Displacement ellipsoids are at the $30 \%$ probability level. $\mathrm{H}$ atoms have been omitted for clarity. 
Table 2. Selected bond lengths $(\AA)$ and angles $\left({ }^{\circ}\right)$ for $(\mathbf{2 Z})^{+},(\mathbf{3 Z})^{+},(\mathbf{5 Z})^{+}$and $(\mathbf{1 1 Z})^{+}$.

\begin{tabular}{ccccc}
\hline & $\mathbf{( 2 Z}^{+}$ & $\mathbf{( 3 Z}^{+}$ & $\mathbf{( 5 Z )}^{+}$ & $\mathbf{( 1 1 Z}^{+}$ \\
\hline $\mathrm{Fe}(1)-\mathrm{Fe}(2)$ & $2.5100(10)$ & $2.5091(9)$ & $2.5023(7)$ & $2.5107(7)$ \\
$\mathrm{Fe}(1)-\mathrm{C}(1)$ & $1.792(7)$ & $1.761(3)$ & $1.759(4)$ & $1.754(4)$ \\
$\mathrm{Fe}(2)-\mathrm{N}(2)$ & $1.924(5)$ & $1.928(3)$ & $1.912(3)$ & $1.918(3)$ \\
$\mathrm{Fe}(1)-\mathrm{C}(2)$ & $1.969(6)$ & $1.964(3)$ & $1.960(4)$ & $1.947(4)$ \\
$\mathrm{Fe}(2)-\mathrm{C}(2)$ & $1.887(6)$ & $1.910(3)$ & $1.896(4)$ & $1.914(4)$ \\
$\mathrm{Fe}(1)-\mathrm{C}(3)$ & $1.884(5)$ & $1.880(3)$ & $1.875(4)$ & $1.880(3)$ \\
$\mathrm{Fe}(2)-\mathrm{C}(3)$ & $1.861(5)$ & $1.863(3)$ & $1.863(4)$ & $1.871(4)$ \\
$\mathrm{Fe}(1)-\mathrm{Cp}$ av & $2.111(13)$ & $2.112(7)$ & $2.110(9)$ & $2.110(7)$ \\
$\mathrm{Fe}(2)-\mathrm{Cp}$ av & $2.095(12)$ & $2.112(7)$ & $2.107(9)$ & $2.102(7)$ \\
$\mathrm{C}(1)-\mathrm{O}(1)$ & $1.092(7)$ & $1.141(4)$ & $1.146(5)$ & $1.143(5)$ \\
$\mathrm{C}(2)-\mathrm{O}(2)$ & $1.157(7)$ & $1.171(4)$ & $1.166(5)$ & $1.166(5)$ \\
$\mathrm{N}(1)-\mathrm{C}(3)$ & $1.288(7)$ & $1.297(4)$ & $1.295(5)$ & $1.290(5)$ \\
$\mathrm{N}(2)-\mathrm{C}(21)$ & $1.126(7)$ & $1.140(4)$ & $1.148(5)$ & $1.133(5)$ \\
$\mathrm{Fe}(1)-\mathrm{C}(1)-\mathrm{O}(1)$ & $177.4(6)$ & $176.6(3)$ & $176.9(3)$ & $179.7(4)$ \\
$\mathrm{Fe}(2)-\mathrm{N}(2)-\mathrm{C}(21)$ & $177.3(5)$ & $175.6(2)$ & $172.8(3)$ & $173.6(3)$ \\
$\mathrm{Fe}(1)-\mathrm{C}(2)-\mathrm{Fe}(2)$ & $81.2(2)$ & $80.73(11)$ & $80.91(14)$ & $81.13(14)$ \\
$\mathrm{Fe}(1)-\mathrm{C}(3)-\mathrm{Fe}(2)$ & $84.2(2)$ & $84.18(12)$ & $84.03(15)$ & $84.03(14)$ \\
$\mathrm{N}(2)-\mathrm{C}(21)-\mathrm{C}(22)$ & $178.3(6)$ & $174.9(3)$ & $178.7(4)$ & $177.7(4)$ \\
$\mathrm{Sum}$ at N(1) & $359.6(8)$ & $360.0(3)$ & $360.0(5)$ & $360.0(5)$ \\
$\mathrm{Sum}$ at C(3) & $359.5(6)$ & $359.8(3)$ & $359.3(4)$ & $359.6(4)$ \\
\hline
\end{tabular}

Table 3 shows crystallographic data for a selection of iron-nitrile complexes from the literature. Regarding acetonitrile complexes, $\mathrm{N} \equiv \mathrm{C}$ bond distances do not change significantly on varying the metal coordination environment, and are close to those found in $(2 \mathrm{Z}) \mathrm{CF}_{3} \mathrm{SO}_{3}$ and $(\mathbf{1 1 Z}) \mathrm{CF}_{3} \mathrm{SO}_{3}$. Instead, the $\mathrm{Fe}-\mathrm{NCMe}$ bond distances in a series of cyclopentadienyl monoiron complexes are finely sensitive to the ligand set, whereas the incidence of the net charge of the complex appears minor. For instance, the Fe-N length is shorter in $\left[\mathrm{Fe}_{2} \mathrm{Cp}_{2}(\mathrm{CO})(\mathrm{NCMe})(\mu-\mathrm{SMe})_{2}\right]^{2+}[1.924(3) \AA]$ than in $\left[\mathrm{FeCp}(\mathrm{CO})_{2}(\mathrm{NCMe})\right]^{+}$ [1.935(4) $\AA$ ], suggesting a higher degree of back-donation in the former complex, despite the higher total charge (+2 vs. +1$)$, favoured by the substantial charge donation from the thiolato-groups. The Fe-NCMe distance reaches the maximum value in $\left[\mathrm{Fe}(\mathrm{NCMe})_{6}\right]^{2+}$, i.e., $2.1510(12) \AA$.

Table 3. X-ray literature data for selected iron-nitrile complexes (with specified formal iron oxidation state) and 4-dimethylaminobenzonitrile. ${ }^{\mathrm{i}} \mathrm{Pr}=\mathrm{CH}\left(\mathrm{CH}_{3}\right)_{2} ; \mathrm{PTA}=1,3$,5-triaza-7-phosphaadamantane.

\begin{tabular}{llll}
\hline & Fe-N (Å) & Ref. \\
\hline
\end{tabular}


Table 3. Cont

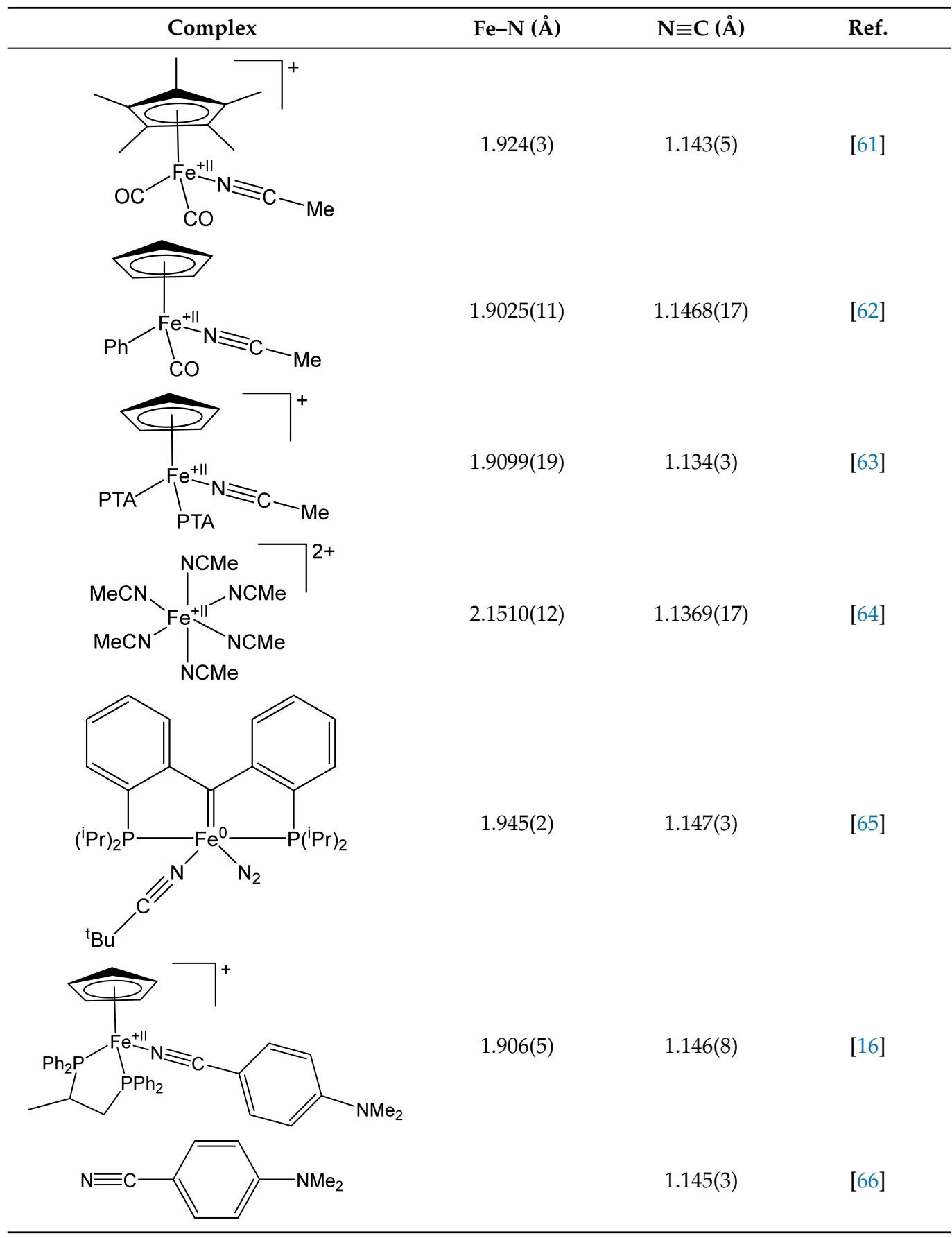

In the iron(0)-pivalonitrile complex $\left[\mathrm{Fe}\left\{=\mathrm{C}\left(2-\mathrm{C}_{6} \mathrm{H}_{4} \mathrm{P}^{\mathrm{i}} \mathrm{Pr}_{2}\right)_{2}\right\}\left(\mathrm{NC} \mathrm{C}^{\mathrm{t}} \mathrm{Bu}\right)\left(\mathrm{N}_{2}\right)\right]$, the $\mathrm{Fe}-\mathrm{N}$ bond is considerably elongated-1.945(2) $\AA$-compared to $(3 \mathrm{Z}) \mathrm{CF}_{3} \mathrm{SO}_{3}[1.928(3) \AA]$.

Interestingly, one other iron complex with the 4-dimethylaminobenzonitrile ligand was previously crystallographically characterized; i.e., the piano-stool [FeCp(Prophos) $\{\mathrm{NC}(4-$ $\left.\left.\left.\mathrm{C}_{6} \mathrm{H}_{4} \mathrm{NMe}_{2}\right)\right\}\right]^{+}$[16]. In this case, the $\mathrm{Fe}^{\mathrm{II}}$-nitrile and $\mathrm{N} \equiv \mathrm{C}$ bond lengths are consistent with the situation in (5Z) $\mathrm{CF}_{3} \mathrm{SO}_{3}$. The $\mathrm{X}$-ray structure of the nitrile molecule is also available, outlining the invariance of the $\mathrm{N} \equiv \mathrm{C}$ bond upon coordination [1.145(3) vs. 1.148(5) $\AA$ in $\left.(5 \mathrm{Z}) \mathrm{CF}_{3} \mathrm{SO}_{3}\right]$.

In summary, the $\mathrm{X}$-ray structures of homologous diiron aminocarbyne complexes and an overview of relevant literature data suggest that both the nitrile substituent and the coordination environment around the iron centre may influence iron-nitrile bonding. 
This feature is noticeable by looking at the Fe- $\mathrm{N}$ bond distance values, whereas the $\mathrm{N} \equiv \mathrm{C}$ distance is almost unvaried in the different cases.

\subsection{DFT Studies}

Initially, we analysed as a model the diiron complex with the most simple nitrile and aminocarbyne substituents; i.e., $\left[\mathrm{Fe}_{2} \mathrm{Cp}_{2}(\mathrm{CO})(\mu-\mathrm{CO})\left(\mu-\mathrm{CNMe}_{2}\right)(\mathrm{NCMe})\right]^{+},[\mathrm{M1}]^{+}[20,67]$. The DFT-computed increment of infrared wavenumber value for the $\mathrm{N} \equiv \mathrm{C}$ bond, with respect to the isolated ligand, is $\Delta \tilde{u}=+2.3 \mathrm{~cm}^{-1}$.

To gain information about iron-nitrile bonding, [M1 $]^{+}$was split into two fragments, i.e., $\left[\mathrm{Fe}_{2} \mathrm{Cp}_{2}(\mathrm{CO})_{2}\left(\mathrm{CNMe}_{2}\right)\right]^{+}$and $\mathrm{NCMe}$. According to energy decomposition analysis (EDA), the dissociation energy BDE is $-46.1 \mathrm{kcal} / \mathrm{mol}$, which is the sum of the interaction energy $E_{\text {int }}(-48.9 \mathrm{kcal} / \mathrm{mol})$ and the deformation energy $(+2.8 \mathrm{kcal} / \mathrm{mol}) . E_{\text {int }}$ can be further divided into steric (sum of the Pauli and the electrostatic term, $E_{s t}, 19.3 \mathrm{kcal} / \mathrm{mol}$ ), dispersion $\left(\mathrm{E}_{\mathrm{disp}},-8.6 \mathrm{kcal} / \mathrm{mol}\right)$ and orbital $\left(\mathrm{E}_{\mathrm{orb}},-59.6 \mathrm{kcal} / \mathrm{mol}\right)$ contributions. The latter is composed of four terms (ETS-NOCV analysis), namely $\Delta \rho_{\mathrm{k}}(\mathrm{k}=0-3$, Figure 4). $\Delta \rho_{0}$ is the most relevant one $\left(\Delta \mathrm{E}_{0}=-33.2 \mathrm{kcal} / \mathrm{mol}\right)$ and, given the position and the local symmetry of the accumulation/depletion regions (blue/red coloured in Figure 4), it is associated with $\mathrm{Fe} \leftarrow \mathrm{N} \sigma$ donation, accompanied by $\mathrm{N} \leftarrow \mathrm{C}$ polarization of the $\mathrm{N} \equiv \mathrm{C}$ bond (see Scheme 1). Notably, accumulation regions are present also on the other iron atom and on the bridging carbonyl ligand. $\Delta \rho_{1}$ is still relevant $\left(\Delta \mathrm{E}_{1}=-11.1 \mathrm{kcal} / \mathrm{mol}\right)$ and can be associated with a $\mathrm{Fe} \rightarrow \mathrm{N} \pi$ back-donation; in this regard, the polarization of the triple bond is $\mathrm{N} \rightarrow \mathrm{C} . \Delta \rho_{2}$ is slightly weaker than $\Delta \rho_{1}\left(\Delta \mathrm{E}_{2}=-9.6 \mathrm{kcal} / \mathrm{mol}\right)$ and is related to $\mathrm{Fe} \rightarrow \mathrm{N} \pi$ back-donation on a plane perpendicular to that for $\Delta \rho_{1}$. The sum of the two back-donation contributions $(20.7 \mathrm{kcal} / \mathrm{mol})$ represents $34.7 \%$ of the total orbital interaction. Finally, $\Delta \rho_{3}$ appears to be a simple $\mathrm{N} \leftarrow$ C polarization of the nitrile, likely due to the electrostatic attraction between the metal and the $\sigma$ electrons on the ligand.

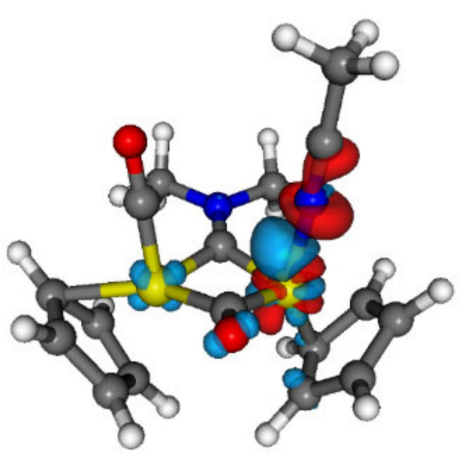

$\Delta \rho_{0}$

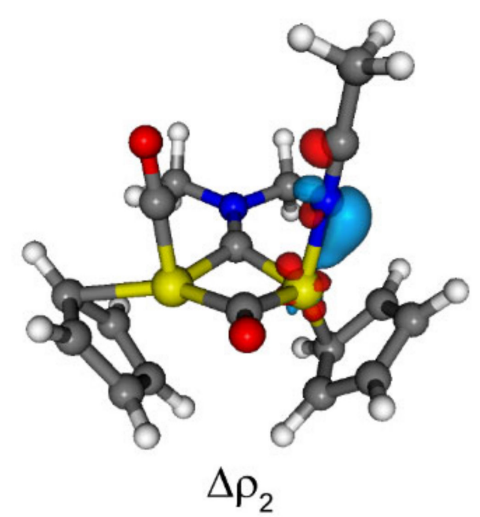

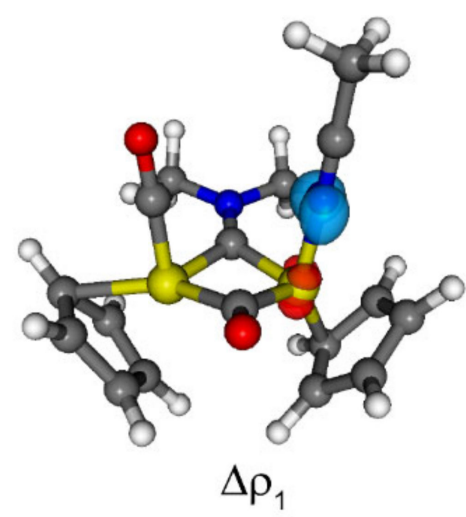

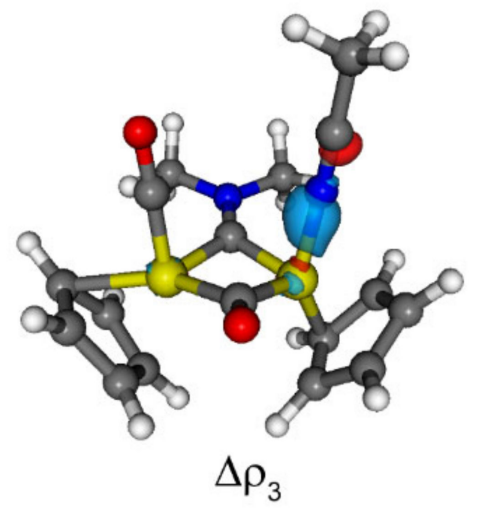

Figure 4. Isodensity surface plots (isodensity value 5 me a.u. ${ }^{-3}$ except for $\Delta \rho_{3}, 2$ me a.u. ${ }^{-3}$ ) for the deformation maps relative to $\Delta \rho_{\mathrm{k}}$ of the $\left[\mathrm{Fe}_{2} \mathrm{Cp}_{2}(\mathrm{CO})_{2}\left(\mathrm{CNMe}_{2}\right)\right]^{+} \ldots \mathrm{NCMe}$ interaction (complex $(\mathbf{M 1})^{+}$. The charge flux is red $\rightarrow$ blue. 
Contributions from $\mathrm{k}>3$ are negligible, with an associated $\Delta \mathrm{E}_{\mathrm{k}}<0.6 \mathrm{kcal} / \mathrm{mol}$. For a more detailed analysis, the different $\Delta \rho_{\mathrm{k}}$ functions can be integrated along the $\mathrm{Fe}-\mathrm{N}$ axis (charge displacement (CD) analysis), affording the $C_{k}$ functions shown in Figure 5. Each of them quantifies, at each point of the space, the number of electrons involved in the electronic rearrangement due to the $\mathrm{Fe}-\mathrm{N}$ bond formation.

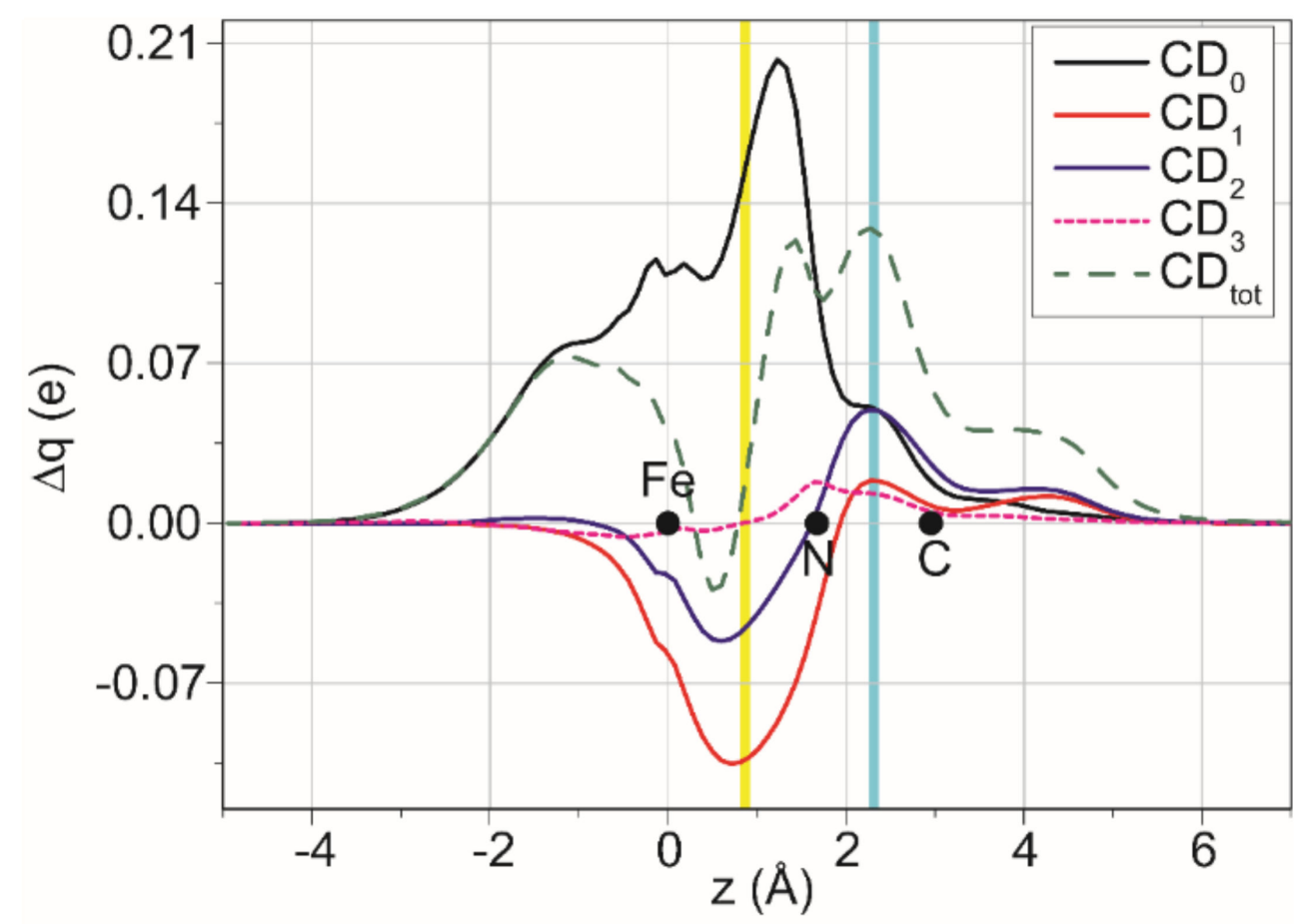

Figure 5. Charge Displacement function related to the $\left[\mathrm{Fe}_{2} \mathrm{Cp}_{2}(\mathrm{CO})_{2}\left(\mathrm{CNMe}_{2}\right)\right]^{+} \cdots \mathrm{NCMe}$ interaction $\left(\right.$ complex $\left.(\mathbf{M} 1)^{+}\right)$. Black dots indicate the position of the atomic nuclei on the axis. The yellow vertical band indicates the boundary between the fragments. The cyan vertical band indicates the half of the $\mathrm{N} \equiv \mathrm{C}$ bond.

In $C D_{k}$ functions, positive and negative values correspond to a charge flux from right to left and left to right, respectively. Indeed, the integration of $\Delta \rho_{0}$ leads to $C_{0}$, which is always positive and describes a displacement of electrons from the ligand to the metallic fragment ( $\sigma$ donation). Between the two fragments (isoboundary), such a displacement is equal to $\mathrm{CT}_{0}=0.167 \mathrm{e}$, whereas at the middle of the triple bond it is $\mathrm{CT}_{\mathrm{CN}, 0}=0.046 \mathrm{e}$, in accordance with the structures $\mathbf{A}$ and $\mathbf{B}$ in Scheme 1, and limited to $\sigma$ electrons. Indeed, there is not one-to-one correspondence between $C D_{k}$ curves and the resonance structures shown in Scheme 1, but each $C D_{k}$ can be seen as a combination of more resonance structures.

The integration of $\Delta \rho_{1}$ and $\Delta \rho_{2}$ leads to $C D_{1}$ and $C D_{2}$, respectively, which display a more complex shape. At the isoboundary, $\mathrm{CT}_{1}$ and $\mathrm{CT}_{2}$ are -0.102 and $-0.043 \mathrm{e}$, thus indicating a remarkable $\mathrm{Fe} \rightarrow \mathrm{N}$ back-donation. The total is $\mathrm{CT}^{\pi}$ tot $=-0.145 \mathrm{e}$, which is only slightly smaller than $\mathrm{CT}_{0}(0.167 \mathrm{e})$. Note that both $\mathrm{CD}_{1}$ and $\mathrm{CD}_{2}$ are positive at the nitrile bond, since the $\mathrm{N} \leftarrow \mathrm{C}$ polarization prevails $\left(\mathrm{CT}_{\mathrm{CN}, 1}=0.018, \mathrm{CT}_{\mathrm{CN}, 2}=0.047 \mathrm{e}\right)$. Being back-donation and polarization opposite in sign, there is a point where the sum of the two functions is null, generally around the $\mathrm{z}$ coordinate of the $\mathrm{N}$ atom. Therefore, despite the large back-donation, the $\mathrm{N} \equiv \mathrm{C}$ bond is reinforced $(\Delta \tilde{\mathrm{u}}>0)$, as the polarization of the $\pi$ electrons due to structures A and $\mathbf{B}$ (Scheme 1) is more than that due to back-donation (structures $\mathbf{C}$ and $\mathbf{D}$ ).

Note that, in terms of displaced electrons, the back-donation is almost equivalent to the donation, $\left(\mathrm{CT}_{1}+\mathrm{CT}_{2}\right) / \mathrm{CT}_{0}=0.86$, whereas in terms of energy the ratio is lower, $\left(\Delta \mathrm{E}_{1}+\Delta \mathrm{E}_{2}\right) / \Delta \mathrm{E}_{0}=0.62$. This depends on the fact that the energy contributions are related to the whole molecule, including all the polarization regions that could be indirectly related 
to the iron-nitrile bond, whereas $\mathrm{CD}$ functions are calculated at a specific point of the molecule (in this case at the boundary between the two fragments $\left[\mathrm{Fe}_{2} \mathrm{Cp}_{2}(\mathrm{CO})_{2}\left(\mathrm{CNMe}_{2}\right)\right]^{+}$ and NCMe, see Computational Details).

Finally, $\Delta \rho_{3}$ can also be integrated, leading to $\mathrm{CD}_{3}$. The latter is negligible in the organometallic region, and slightly positive within the $\mathrm{N} \equiv \mathrm{C}$ bond. As pointed out before, this is a small, additional polarization of the $\mathrm{N} \equiv \mathrm{C}$ bond ( $0.012 \mathrm{e}$ ) upon coordination to the iron. The latter contribution is coherent with structure $\mathbf{A}$ in Scheme 1. The total polarization of the triple bond is $\mathrm{CT}_{\mathrm{CN}}=0.121 \mathrm{e}$. The sum of all components between the iron and the nitrogen is $\mathrm{CT}_{\text {tot }}=0.034 \mathrm{e}$.

The polarization is remarkable even in the region of the methyl group $(\Delta \mathrm{q}=0.036 \mathrm{e}$, at the carbon, and $0.017 \mathrm{e}$, at the hydrogen atoms). The electronic polarization of the methyl group is in alignment with the marked acidity manifested by the acetonitrile ligand in diiron aminocarbyne complexes, ${ }^{21 a}$ as well as in other organometallic systems $[68,69]$. We extended the computational analysis to the terminal $\{\mathrm{Fe}-\mathrm{CO}\}$ bond within $(\mathrm{M1})^{+}$(Figure S48) and we found that the interaction energy is much stronger for $\{\mathrm{Fe}-\mathrm{CO}\}$ than $\{\mathrm{Fe}-\mathrm{NCMe}\}$ $\left(\mathrm{E}_{\mathrm{int}}=-65.7 \mathrm{kcal} / \mathrm{mol} \mathrm{vs}\right.$. $\left.-45.4 \mathrm{kcal} / \mathrm{mol}\right)$. In addition, for $\{\mathrm{Fe}-\mathrm{CO}\}$, the orbital contribution of back-donation $\left(E_{1}+E_{2}=-56.1 \mathrm{kcal} / \mathrm{mol}\right)$ is even larger than the orbital contribution of the donation $\left(\mathrm{E}_{0}=-49.2 \mathrm{kcal} / \mathrm{mol}\right)$, while the contrary occurs for $\{\mathrm{Fe}-\mathrm{NCMe}\}$ $\left(\mathrm{E}_{1}+\mathrm{E}_{2}=-20.7 \mathrm{kcal} / \mathrm{mol}, \mathrm{E}_{0}=-33.2 \mathrm{kcal} / \mathrm{mol}\right)$.

The same framework as that described for the model adduct $(\mathbf{M 1})^{+}$retains its validity in the nitrile complexes $(2-7)^{+}$, with numerical differences depending on the nitrile (R) and aminocarbyne (Y), substituents which are detailed in Table 4. A view of the DFT-optimized structures of (2-7) ${ }^{+}$is provided as Supplementary Materials (Figure S49).

Table 4. Calculated infrared wavenumber shift $\left(\Delta \tilde{u}\right.$, in $\left.\mathrm{cm}^{-1}\right)$ upon coordination of nitriles to diiron complexes, bond dissociation energy (BDE, in $\mathrm{kcal} / \mathrm{mol})$, orbital contributions $\left(\Delta \mathrm{E}_{\mathrm{k}}\right.$, in $\left.\mathrm{kcal} / \mathrm{mol}\right)$ and charge transfer $\left(\mathrm{CT}_{\mathrm{k}}\right)$ values (in electrons). $\mathrm{k}=0$ is related to $\sigma$ donation, $\mathrm{k}=1$ and 2 are related to $\pi$ back-donation. $\mathrm{CT}_{\text {tot }}$ is the net charge transfer; $\mathrm{CT}^{\pi}$ tot $=\mathrm{CT}_{1}+\mathrm{CT}_{2}$. $\%$ of $\pi$-back-donation (\% b.d.) calculated as: $\left(\Delta \mathrm{E}_{1}+\Delta \mathrm{E}_{2}\right) / \Delta \mathrm{E}_{\mathrm{orb}} \cdot(\mathbf{M 1})^{+}=\left[\mathrm{Fe}_{2} \mathrm{Cp}_{2}(\mathrm{CO})(\mu-\mathrm{CO})\left\{\mu-\mathrm{CNMe}{ }_{2}\right\}(\mathrm{NCMe})\right]^{+}$, $\left.\mathbf{~ ( M 2 ) ~}^{+}=\left[\mathrm{Fe}_{2} \mathrm{Cp}_{2}(\mathrm{CO})(\mu-\mathrm{CO})\{\mu-\mathrm{CNMe}(\mathrm{Cy})\}\left(\mathrm{N} \equiv \mathrm{CCF}_{3}\right)\right]^{+}, \quad \mathbf{M} 3\right)^{+}=\left[\mathrm{Fe}_{2} \mathrm{Cp}_{2}(\mathrm{CO})(\mu-\mathrm{CO})\{\mu-\mathrm{CNMe}(\mathrm{Cy})\}\left(\mathrm{N} \equiv \mathrm{CCHF}_{2}\right)\right]^{+}$, $\mathbf{( M 4}^{+}=\left[\mathrm{Fe}_{2} \mathrm{Cp}_{2}(\mathrm{CO})(\mu-\mathrm{CO})\{\mu-\mathrm{CNMe}(\mathrm{Cy})\}\left(\mathrm{N} \equiv \mathrm{CCH}_{2} \mathrm{~F}\right)\right]^{+}$(model complexes, see Figure S50).

\begin{tabular}{|c|c|c|c|c|c|c|c|c|}
\hline Comp. & $\Delta \tilde{u}$ & BDE & $\Delta \mathrm{E}_{0}\left(\mathrm{CT}_{0}\right)$ & $\Delta \mathrm{E}_{1}\left(\mathrm{CT}_{1}\right)$ & $\Delta \mathrm{E}_{2}\left(\mathrm{CT}_{2}\right)$ & $\mathrm{CT}_{\text {tot }}\left(\mathrm{CT}^{\pi}{ }_{\text {tot }}\right)$ & $\mathrm{CT}_{\mathrm{CN}}\left(\mathrm{CT}^{\pi}{ }_{\mathrm{CN}}\right)$ & $\%$ b.d. \\
\hline (M1) $^{+}$ & +2.3 & -46.1 & $-33.2(0.167)$ & $-11.1(-0.102)$ & $-9.6(-0.043)$ & $0.034(-0.145)$ & $0.121(0.065)$ & 34.7 \\
\hline$(2 Z)^{+}{ }_{\exp }^{a}$ & - & - & $-30.2(0.158)$ & $-9.1(-0.085)$ & $-7.6(-0.034)$ & $0.048(-0.119)$ & $0.108(0.063)$ & 31.9 \\
\hline$(2 Z)^{+}$ & +2.5 & -46.3 & $-33.7(0.167)$ & $-11.5(-0.107)$ & $-9.6(-0.038)$ & $0.029(-0.145)$ & $0.111(0.054)$ & 34.8 \\
\hline$(2 E)^{+}$ & +2.2 & -46.6 & $-33.6(0.168)$ & $-11.4(-0.106)$ & $-9.6(-0.043)$ & $0.030(-0.149)$ & $0.113(0.064)$ & 35.0 \\
\hline$(3 E)^{+}$ & +1.8 & -50.0 & $-34.1(0.173)$ & $-11.2(-0.100)$ & $-9.5(-0.043)$ & $0.043(-0.143)$ & $0.113(0.071)$ & 33.7 \\
\hline$(4 E)^{+}$ & -4.4 & -50.9 & $-34.5(0.176)$ & $-13.5(-0.126)$ & $-10.1(-0.044)$ & $0.021(-0.170)$ & $0.116(0.063)$ & 36.6 \\
\hline$(5 E)^{+}$ & 1.2 & -56.1 & $-35.4(0.182)$ & $-11.9(-0.096)$ & $-9.4(-0.040)$ & $0.062(-0.136)$ & $0.150(0.102)$ & 33.2 \\
\hline$(6 E)^{+}$ & -16.2 & -47.7 & $-33.9(0.169)$ & $-15.7(-0.119)$ & $-10.9(-0.046)$ & $0.005(-0.165)$ & $0.086(0.032)$ & 39.8 \\
\hline$(7 E)^{+}$ & -5.0 & -50.0 & $-34.5(0.178)$ & $-13.4(-0.124)$ & $-10.2(-0.045)$ & $0.024(-0.169)$ & $0.114(0.062)$ & 36.5 \\
\hline$(\mathrm{M} 2)^{+}$ & -62.7 & -42.5 & $-32.5(0.108)$ & $-18.1(-0.178)$ & $-15.0(-0.039)$ & $-0.099(-0.217)$ & $0.032(-0.051)$ & 46.6 \\
\hline (M3) $^{+}$ & -48.9 & -44.1 & $-33.2(0.132)$ & $-16.7(-0.169)$ & $-13.7(-0.044)$ & $-0.071(-0.213)$ & $0.049(0.00)$ & 44.0 \\
\hline$(\mathrm{M} 4)^{+}$ & -35.2 & -46.0 & $-33.5(0.154)$ & $-16.1(-0.159)$ & $-11.0(-0.046)$ & $-0.040(-0.205)$ & $0.068(0.011)$ & 40.8 \\
\hline
\end{tabular}

As the crystal structure of [2Z]CF $\mathrm{SO}_{3}$ is available (Figure 3), we applied the NOCV$\mathrm{CD}$ analysis to both the experimental geometry without further optimization $\left(\left(\mathbf{2 Z}_{\mathbf{e x p}}\right)^{+}\right)$ and the optimized geometry $\left((2 \mathrm{Z})^{+}\right)$, to evaluate the influence of crystal lattice on the $\mathrm{Fe}-\mathrm{N}$ bond (Table 4). Indeed, there is a difference in the experimental and computed bond lengths, as the $\mathrm{Fe}-\mathrm{N}$ and $\mathrm{N}-\mathrm{C}$ distances measure 1.924(5) and 1.126(7) $\AA$ in the crystal structure and 1.865 and $1.163 \AA$ in the optimized geometry, respectively. Such a difference is reflected on the bonds in $\left(\mathbf{2} Z_{\exp }\right)^{+}$and $(\mathbf{2 Z})^{+}:$in the former, both $\sigma$ and $\pi$ contributions are smaller than in the latter, in absolute value, in terms of energy and electrons. This is 
likely due to the longer Fe-N distance in $\left(2 Z_{\mathbf{e x p}}\right)^{+}$, as all the bonding contributions decrease as distance increases.

By comparing the bond splitting in $(\mathbf{2 Z})^{+}$and in $(\mathbf{M 1})^{+}$, the contributions are strikingly similar, indicating that the presence on the aminocarbyne ligand of a cyclohexyl group $\left((\mathbf{Z Z})^{+}\right)$, rather than a methyl $\left((\mathbf{M 1})^{+}\right)$, does not substantially affect the iron-nitrile bonding. NOCV-CD analysis on the isomer $(2 \mathrm{E})^{+}$led to almost identical values as $(2 \mathrm{Z})^{+}$, revealing that the relative geometry of the nitrile and the cyclohexyl is also not important. Accordingly, the calculated $\Delta \tilde{u}$ does not change significantly $\left(+2.3 \mathrm{~cm}^{-1}\right.$ in $(\mathbf{M 1})^{+},+2.5 \mathrm{~cm}^{-1}$ in $(2 \mathrm{Z})^{+},+2.2 \mathrm{~cm}^{-1}$ in $\left.(2 \mathrm{E})^{+}\right)$.

A systematic NOCV-CD analysis was carried out on complexes $(2-7)^{+}$(E isomers). An acceptable correlation exists between experimental and computed $\Delta \tilde{u}$ values $\left(r^{2}=0.85\right)$, although the former are systematically lower than the latter. As these complexes show quite close experimental $\Delta \tilde{u}$ values (Table 1 ), additional theoretical systems $\left[\mathrm{Fe}_{2} \mathrm{Cp}_{2}(\mathrm{CO})\right.$ $(\mu-\mathrm{CO})\{\mu-\mathrm{CNMe}(\mathrm{Cy})\}(\mathrm{NCR})]^{+}$with fluorinated nitriles were included to widen the spectral window of the analysis $\left(\mathrm{R}=\mathrm{CF}_{3},(\mathbf{M} 2)^{+} ; \mathrm{R}=\mathrm{CHF}_{2},(\mathbf{M} 3)^{+} ; \mathrm{R}=\mathrm{CH}_{2} \mathrm{~F},(\mathbf{M} 4)^{+}\right.$; see Figure S50, Supplementary Materials).

The orbital energy associated with the back-donation ranges from $31.9 \%$ to $46.6 \%$ of the total bonding interaction. Looking at the CT values, back-donation roughly increases its relative weight on increasing the electron-withdrawing character of $\mathrm{R}$, although clear deviations from this trend are noticeable; more precisely, the $\mathrm{CT}^{\pi}$ tot $/ \mathrm{CT}_{0}$ ratios vary from $0.75\left([5]^{+}\right)$to $2.01\left((\mathbf{M} 2)^{+}\right)$, along the sequence $(5)^{+}<(3)^{+}<(2)^{+}<(7)^{+}<(4)^{+}<(6)^{+}<(\mathbf{M} 4)^{+}<(\mathbf{M} 3)^{+}<(\mathrm{M} 2)^{+}$. On the other hand, the computed Fe-N bond energy (in absolute value) increases in the order $(\mathrm{M} 2)^{+}<(\mathrm{M} 3)^{+}<(\mathrm{M} 4)^{+}<(2)^{+}<(6)^{+}<(3)^{+}=(7)^{+}<(4)^{+}<(5)^{+}$, pointing out that an appropriate balance of s-donation and $\mathrm{p}$-back donation may be beneficial to the iron-nitrile bond stability. Interestingly, complex $(5)^{+}\left(\mathrm{R}=4-\mathrm{C}_{6} \mathrm{H}_{4} \mathrm{NMe}_{2}\right)$ combines the lowest $\mathrm{CT}^{\pi}$ tot $/ \mathrm{CT}_{0}$ ratio with the highest $\mathrm{BDE}$ of the series: the special strength of the coordination of 4-dimethylaminobenzonitrile in $(5)^{+}$agrees with experimental findings on another iron system (see Introduction) [16].

Regarding the $\{\mathrm{N} \equiv \mathrm{C}\}$ polarization, $\mathrm{CT}_{\mathrm{CN}}$ is always positive $(\mathrm{N} \leftarrow \mathrm{C})$ and remarkable, ranging from $0.032 \mathrm{e}\left((\mathbf{M} 2)^{+}\right)$to $0.150 \mathrm{e}\left((5 \mathrm{E})^{+}\right)$. Considering only the $\pi$ contribution $\left(\mathrm{CT}^{\pi}{ }_{\mathrm{CN}}\right)$, the polarization may become null when opposing electron fluxes counterbalance each other $\left((\mathbf{M} 3)^{+}\right)$, or even negative $\left(-0.051 \mathrm{e},(\mathbf{M} 2)^{+}\right)$. As explained above for $(\mathbf{M 1})^{+}$, in general the $\mathrm{N} \leftarrow \mathrm{C}$ polarization due to electrostatic and $\sigma$ metal-nitrile interactions is not sufficiently balanced by back-donation from iron (Scheme 1), resulting in a positive value of $\Delta \tilde{u}$ and favouring nucleophilic attack at the nitrile carbon (see Introduction) [46-48]. In the presence of significantly $\pi$-acidic substituents on the nitrile, the polarization may be inverted $(\mathrm{N} \rightarrow \mathrm{C}$ ), leading to negative $\Delta \tilde{u}$ values. Therefore, it has to be remarked that a positive value of $\Delta \tilde{u}$ is not an index of absence of back-donation, in analogy to what previously demonstrated for carbonyl complexes, ${ }^{41}$ and advising caution in the interpretation of the metal-nitrile bonding based on infrared data only $[1,10,12,70,71]$.

The computed $\Delta \tilde{u}$ values in Table 4 correlate well with the relevant bond contributions, the correlation factors varying from 0.89 (with $\mathrm{CT}^{\pi}$ tot and $\mathrm{CT}_{\mathrm{CN} \text {,tot }}$ ) to 0.97 (with $\mathrm{CT}_{\text {tot }}$, see Figure 6). It can be concluded that the Fe $\rightarrow \mathrm{N} \equiv \mathrm{CR}$ back-donation is important and tunable, and appreciably influences the IR vibration of the $\mathrm{N} \equiv \mathrm{C}$ bond. Similarly, it was proposed for carbonyl complexes that the experimental infrared stretching wavenumber is proportional to the degree of metal to $\mathrm{CO} \pi$-back-donation and, more precisely, to the polarization of the $\pi$ electrons on the carbon-oxygen bond [72-74]. 


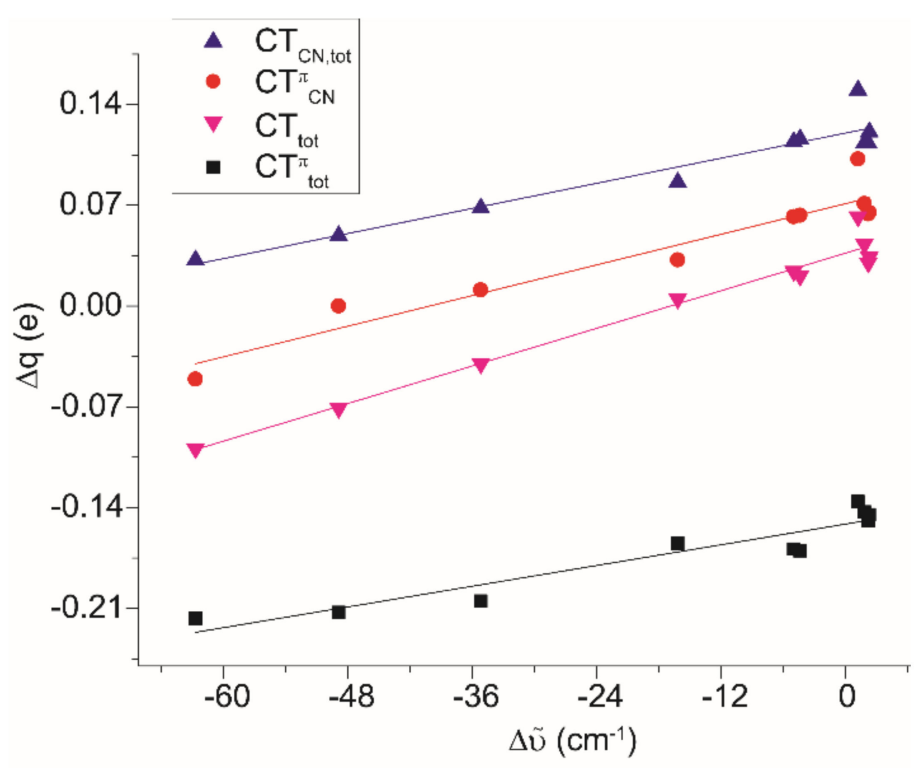

Figure 6. Correlation between bond components and IR frequency shifts (calculated $\Delta \tilde{u})$ for complexes (M1-M4) ${ }^{+}$and (2-7) ${ }^{+}$(see Table 4). Correlation factors are $\mathrm{r}^{2}=0.89$ for $\mathrm{CT}^{\pi}{ }_{\text {tot }}, 0.90$ for $\mathrm{CT}^{\pi} \mathrm{CN}$, 0.89 for $\mathrm{CT}_{\mathrm{CN} \text {,tot }}$ and 0.97 for $\mathrm{CT}_{\text {tot }}$.

\section{Conclusions}

Nitriles $(\mathrm{N} \equiv \mathrm{CR}$ ) have been largely employed in coordination chemistry and, despite being regarded in several cases as relatively weak ligands, the occurrence of metal to nitrile $\pi$-back-donation has been proposed. To support this view, experimental and theoretical proofs have been supplied with reference to diverse metal systems, but a comprehensive crystallographic, spectroscopic and computational approach is rare in the literature. Here, we have exploited an easily accessible di-organoiron scaffold to explore the bonding between one iron centre and a range of nitriles, using X-ray, IR, NMR and DFT methods.

Computational results outlined that the relative contribution of $\mathrm{Fe} \rightarrow \mathrm{N} \pi$-backdonation is normally strong but only marginally dependent on the nature of the nitrile. A comparative view of $\mathrm{X}$-ray structures, extended to additional literature iron compounds, highlighted that different nitrile substituents $(\mathrm{R})$ may affect the $\mathrm{Fe}-\mathrm{N}$ bond distance but not the $\mathrm{N} \equiv \mathrm{C}$ one. More finely, the shifts of infrared stretching vibration $(\Delta \widetilde{\mathrm{u}})$ and ${ }^{13} \mathrm{C} N M R$ resonance $(\Delta \delta)$ related to the nitrile function upon coordination to the metal rigorously correlate with the electronic properties of R. Besides, DFT studies clarify that a positive value of $\Delta \tilde{u}$ is not evidence for a lack of back-donation, as sometimes misconceived in the literature; a parallelism emerges between metal-nitrile and metal-carbonyl bonds, in terms of the relationship between IR stretching vibration and ligand polarization, with the necessary distinctions in terms of donation/back-donation ratio. Note that IR and NMR data clearly demonstrate an interplay between the nitrile ligand and the strongly $\pi$-acceptor bridging aminocarbyne ligand. Overall, the established scales of $\Delta \tilde{u}, \Delta \delta$ and ${ }^{13} \mathrm{C}$ NMR carbyne resonance values are indicators of the electronic behaviour of $R$ holding a predictive potential in such regard. Nevertheless, the degree of back-donation is not strictly correlated with the electron withdrawing power of R; furthermore, increasing the backdonation does not seem a guarantee of strengthening the iron-nitrile bond. DFT outcomes, partially supported here by experimental X-ray analysis, indicate $\mathrm{N} \equiv \mathrm{C}\left(4-\mathrm{C}_{6} \mathrm{H}_{4} \mathrm{NMe}_{2}\right)$ as a convenient choice for a nitrile ligand pointing to a relatively stable metal coordination.

\section{Experimental}

\subsection{Materials and Methods}

Reactants and solvents were obtained from Alfa Aesar, Merck, Strem and TCI Chemicals and were of the highest purity available. Complexes $(\mathbf{1 a}, \mathbf{c}, \mathbf{d}) \mathrm{CF}_{3} \mathrm{SO}_{3}$ [43] and $(\mathbf{1 b}) \mathrm{CF}_{3} \mathrm{SO}_{3}$ [27] were prepared according to the literature. Once isolated, all the products were stored under 
$\mathrm{N}_{2}$, or under air, for limited periods of time ( $<3$ days). Synthetic procedures were conducted under $\mathrm{N}_{2}$ atmosphere using standard Schlenk techniques. $\mathrm{CH}_{2} \mathrm{Cl}_{2}$ and THF were dried with the solvent purification system mBraun MB SPS5, while MeCN was distilled from $\mathrm{CaH}_{2}$. Chromatography separations were carried out on columns of deactivated alumina (Merck, $4 \% w / w$ water). IR spectra of solutions were recorded using a $\mathrm{CaF}_{2}$ liquid transmission cell $\left(2300-1500 \mathrm{~cm}^{-1}\right)$ on a Perkin Elmer Spectrum 100 FT-IR spectrometer. IR spectra of solid samples $\left(650-4000 \mathrm{~cm}^{-1}\right)$ and liquid nitriles (acetonitrile and trimethylacetonitrile [49]) were recorded on a Perkin Elmer Spectrum One FT-IR spectrometer, equipped with a UATR sampling accessory. IR spectra were processed with Spectragryph software [75]. NMR spectra were recorded at $298 \mathrm{~K}$ on a Bruker Avance II DRX400 instrument equipped with a BBFO broadband probe. Chemical shifts (expressed in parts per million) are referenced to the residual solvent peaks [76] or to external standard $\left({ }^{19} \mathrm{~F}, \mathrm{CFCl}_{3}\right)$. NMR spectra were assigned with the assistance of ${ }^{1} \mathrm{H}^{-13} \mathrm{C}(\mathrm{gs}-\mathrm{HSQC}$ and gs-HMBC) correlation experiments [77]. NMR signals due to secondary isomeric forms (where it has been possible to detect them) are italicized. Figures 7-17 show the prevalent isomer detected by NMR for each case. Elemental analyses were performed on a Vario MICRO cube instrument (Elementar).

\subsection{Synthesis and Characterization of Compounds}

4.2.1. Synthesis and Characterization of $\left[\mathrm{Fe}_{2} \mathrm{Cp}_{2}(\mathrm{CO})(\mathrm{NCMe})(\mu-\mathrm{CO})\{\mu-\mathrm{CN}(\mathrm{Me})(\mathrm{Cy})\}\right] \mathrm{CF}_{3} \mathrm{SO}_{3}$, (2) $\mathrm{CF}_{3} \mathrm{SO}_{3}$

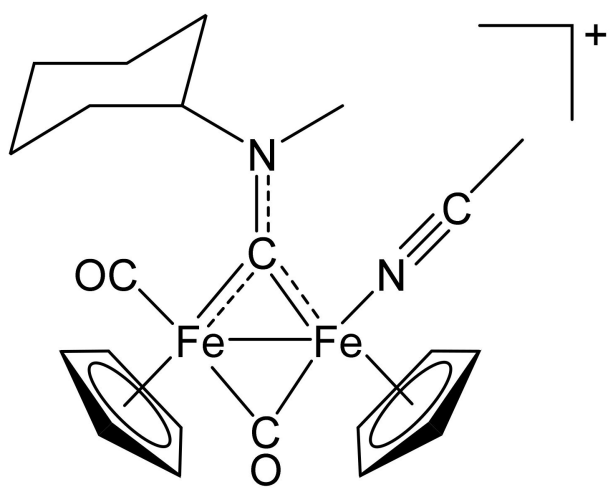

Figure 7. Structure of the cation of $(2) \mathrm{CF}_{3} \mathrm{SO}_{3}$.

In a $25 \mathrm{~mL}$ Schleck tube, a mixture of $(\mathbf{1 a}) \mathrm{CF}_{3} \mathrm{SO}_{3}(233 \mathrm{mg}, 0.389 \mathrm{mmol}), \mathrm{Me}_{3} \mathrm{NO} \cdot 2 \mathrm{H}_{2} \mathrm{O}$ (48 mg, $0.43 \mathrm{mmol}$ ) and $\mathrm{MeCN}(5 \mathrm{~mL})$ was stirred for $2 \mathrm{~h}$ at room temperature. Afterwards, volatiles were evaporated under vacuum; the solid residue was dissolved in $\mathrm{CH}_{2} \mathrm{Cl}_{2}$ and the solution charged on an alumina column. Elution with THF allowed to separate impurities, then the fraction corresponding to the title compound was eluted using neat $\mathrm{MeCN}$. Solvent was removed under reduced pressure and the residue was suspended in $\mathrm{Et}_{2} \mathrm{O}(50 \mathrm{~mL})$ for $2 \mathrm{~h}$. The brown powder was recovered by filtration and dried under vacuum. The yield was $180 \mathrm{mg}(76 \%)$; soluble in $\mathrm{MeCN}, \mathrm{CH}_{2} \mathrm{Cl}_{2}$, acetone; insoluble in $\mathrm{Et}_{2} \mathrm{O}$; X-ray quality crystals of $(2) \mathrm{CF}_{3} \mathrm{SO}_{3}$ were obtained from a MeCN solution layered with $\mathrm{Et}_{2} \mathrm{O}$ and settled aside at $-20{ }^{\circ} \mathrm{C}$. Anal. calcd. for $\mathrm{C}_{23} \mathrm{H}_{27} \mathrm{~F}_{3} \mathrm{Fe}_{2} \mathrm{~N}_{2} \mathrm{O}_{5} \mathrm{~S}$ : C, 45.12; $\mathrm{H}, 4.44 ; \mathrm{N}, 4.57 ; \mathrm{S}, 5.24$. Found: $\mathrm{C}, 45.21 ; \mathrm{H}, 4.40 ; \mathrm{N}, 4.50 ; \mathrm{S}, 5.31$. IR (solid): $\tilde{\mathrm{v}} / \mathrm{cm}^{-1}=2279 \mathrm{vw}$ $(\mathrm{C} \equiv \mathrm{N}), 1966$ vs $(\mathrm{CO}), 1807 \mathrm{~s}(\mu-\mathrm{CO}), 1543 \mathrm{~m}(\mu-\mathrm{CN}) . \mathrm{IR}\left(\mathrm{CH}_{2} \mathrm{Cl}_{2}\right): \tilde{v} / \mathrm{cm}^{-1}=2277 \mathrm{w}(\mathrm{C} \equiv \mathrm{N})$, 1985 vs (CO), $1818 \mathrm{~s}(\mu-\mathrm{CO}), 1561 \mathrm{w}(\mu-\mathrm{CN}), 1540 \mathrm{w} . \mathrm{IR}(\mathrm{MeCN}): \tilde{\nu} / \mathrm{cm}^{-1}=1980 \mathrm{~s}(\mathrm{CO})$, $1811 \mathrm{~s}(\mu-\mathrm{CO}), 1562 \mathrm{~m}(\mu-\mathrm{CN}), 1543 \mathrm{~m} .{ }^{1} \mathrm{H}$ NMR $\left(\mathrm{CDCl}_{3}\right): \delta / \mathrm{ppm}=5.78,5.0 *(\mathrm{t}, J=12 \mathrm{~Hz}$, $1 \mathrm{H}, \mathrm{CH}^{\mathrm{Cy}}$ ); 5.20, 5.16, 5.01, 4.98 (s, $10 \mathrm{H}, \mathrm{Cp}$ ); 4.53, 4.21 (s, $3 \mathrm{H}, \mathrm{NMe}$ ); 2.86, 2.85 (s, $3 \mathrm{H}$, $\mathrm{NCMe}) ; 2.73,2.58,2.36-2.12,2.02-1.35\left(\mathrm{~m}, 10 \mathrm{H}, \mathrm{CH}_{2}{ }^{\mathrm{Cy}}\right) .{ }^{*}$ Hidden by $\mathrm{Cp}$ resonances. ${ }^{13} \mathrm{C}\left\{{ }^{1} \mathrm{H}\right\} \mathrm{NMR}\left(\mathrm{CDCl}_{3}\right): \delta / \mathrm{ppm}=330.5(\mu-\mathrm{CN}) ; 266.7(\mu-\mathrm{CO}) ; 213.2,212.3(\mathrm{CO}) ; 132.0,131.8$ $(\mathrm{C} \equiv \mathrm{N}) ; 89.6,89.4,87.7,87.6(\mathrm{Cp}) ; 78.4,77.7\left(\mathrm{CH}^{\mathrm{Cy}}\right)$; 46.1, $45.3(\mathrm{NMe}) ; 32.7,32.1,31.6,26.4$, $26.3,26.2,25.9\left(\mathrm{CH}_{2}{ }^{\mathrm{Cy}}\right) ; 3.6(\mathrm{NCMe})$. Isomer ratio $(\mathrm{E} / \mathrm{Z})=65: 35$. 
4.2.2. General Procedure for the Synthesis of $(3-10) \mathrm{CF}_{3} \mathrm{SO}_{3}$

In a Schlenk tube, the starting complex $\left((\mathbf{1 a}) \mathrm{CF}_{3} \mathbf{S O}_{3}\right.$ or $\left.(\mathbf{1 b}) \mathbf{C F}_{3} \mathbf{S O}_{3}\right)$ and $\mathrm{Me}_{3} \mathrm{NO} \cdot 2 \mathrm{H}_{2} \mathrm{O}$ (1.1 eq.) were dissolved in THF $(7 \mathrm{~mL})$; then, the appropriate organic reactant (ca. 3.5 eq.) was added. The mixture was stirred for $2 \mathrm{~h}$ at room temperature, and then charged on an alumina column. Elution with $\mathrm{CH}_{2} \mathrm{Cl}_{2}$ and with $\mathrm{CH}_{2} \mathrm{Cl}_{2} / \mathrm{THF}$ mixture $(2: 1 \mathrm{v} / v)$ allowed the separation of impurities, then the fraction corresponding to the product was collected using THF/MeOH mixture (10:1 $v / v)$. Volatiles were evaporated under reduced pressure, and the residue was suspended in $\mathrm{Et}_{2} \mathrm{O}(15 \mathrm{~mL})$ for $2 \mathrm{~h}$. The obtained powder was recovered by filtration and dried under vacuum.

\section{$\left[\mathrm{Fe}_{2} \mathrm{Cp}_{2}(\mathrm{CO})\left(\mathrm{NCCMe}_{3}\right)(\mu-\mathrm{CO})\{\mu-\mathrm{CN}(\mathrm{Me})(\mathrm{Cy})\}\right] \mathrm{CF}_{3} \mathrm{SO}_{3},(3) \mathrm{CF}_{3} \mathrm{SO}_{3}$}

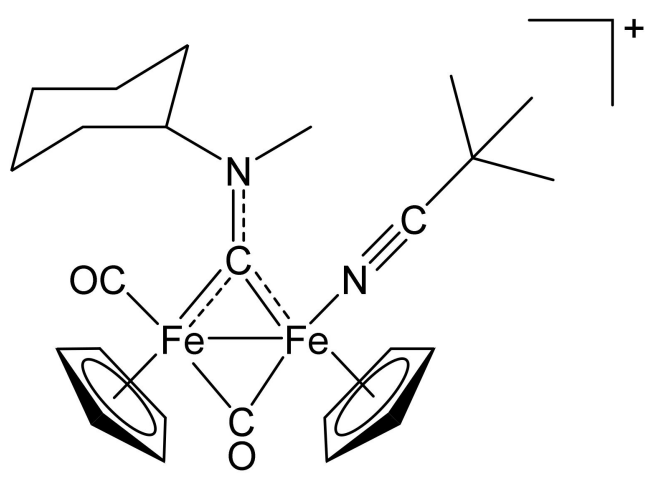

Figure 8. Structure of the cation of $(3) \mathrm{CF}_{3} \mathrm{SO}_{3}$.

From (1a) $\mathrm{CF}_{3} \mathrm{SO}_{3}(100 \mathrm{mg}, 0.167 \mathrm{mmol})$ and trimethylacetonitrile $(65 \mu \mathrm{L}, 0.58 \mathrm{mmol})$. Dark-brown solid, yield $75 \mathrm{mg}(69 \%)$. X-ray quality crystals of $(3) \mathrm{CF}_{3} \mathrm{SO}_{3}$ were obtained from a $\mathrm{CH}_{2} \mathrm{Cl}_{2}$ solution layered with pentane and settled aside at $-20^{\circ} \mathrm{C}$. Anal. calcd. for $\mathrm{C}_{26} \mathrm{H}_{33} \mathrm{~F}_{3} \mathrm{Fe}_{2} \mathrm{~N}_{2} \mathrm{O}_{5} \mathrm{~S}$ : C, 47.73; H, 5.08; N, 4.28; S, 4.90 Found: $\mathrm{C}, 47.75 ; \mathrm{H}, 5.10 ; \mathrm{N}, 4.19$; $\mathrm{S}, 4.81$. IR (solid state): $\tilde{\nu} / \mathrm{cm}^{-1}=2264 \mathrm{w}(\mathrm{C} \equiv \mathrm{N}), 1967 \mathrm{vs}$. $(\mathrm{CO}), 1799 \mathrm{~s}(\mu-\mathrm{CO}), 1544 \mathrm{~m}$ $(\mu-\mathrm{CN})$. IR $\left(\mathrm{CH}_{2} \mathrm{Cl}_{2}\right): \tilde{v} / \mathrm{cm}^{-1}=2264 \mathrm{w}(\mathrm{C} \equiv \mathrm{N}), 1984 \mathrm{vs}(\mathrm{CO}), 1820 \mathrm{~s}(\mu-\mathrm{CO}), 1559 \mathrm{w}(\mu-\mathrm{CN})$. ${ }^{1} \mathrm{H}$ NMR (acetone- $\left.\mathrm{d}_{6}\right): \delta / \mathrm{ppm}=5.79,5.0 *\left(\mathrm{~m}, 1 \mathrm{H}, \mathrm{CH}^{\mathrm{Cy}}\right) ; 5.22,5.18,5.03,4.98(\mathrm{~s}, 10 \mathrm{H}, \mathrm{Cp})$; 4.54, 4.22 (s, $3 \mathrm{H}, \mathrm{NMe}) ; 2.74,2.59,2.35-2.14,1.93-1.56,1.40-1.22\left(\mathrm{~m}, 10 \mathrm{H}, \mathrm{CH}_{2}{ }^{\mathrm{Cy}}\right) ; 1.08,1.06$ $\left(\mathrm{s}, 9 \mathrm{H}, \mathrm{CMe}_{3}\right) .{ }^{*}$ Hidden by $\mathrm{Cp}$ resonances. ${ }^{13} \mathrm{C}\left\{{ }^{1} \mathrm{H}\right\}$ NMR (acetone- $\left.\mathrm{d}_{6}\right): \delta / \mathrm{ppm}=330.7$, $330.1(\mu-\mathrm{CN}) ; 266.7,266.1$ ( $\mu-\mathrm{CO}) ; 213.6,212.6(\mathrm{CO}) ; 140.0,139.8(\mathrm{C} \equiv \mathrm{N}) ; 89.8,89.6,88.1,87.9$ (Cp); 78.4, 77.9 (CH $\left.{ }^{\mathrm{Cy}}\right) ; 46.3,45.3(\mathrm{NMe}) ; 35.1,33.1,32.1,31.7,31.4,30.8,26.4,26.3,26.0,25.9$ $\left(\mathrm{CH}_{2}{ }^{\mathrm{Cy}}\right) ; 27.7\left(\mathrm{CMe}_{3}\right) ; 27.6\left(\mathrm{CMe}_{3}\right)$. Isomer ratio $(\mathrm{E} / \mathrm{Z})=70: 30$.

\section{$\left[\mathrm{Fe}_{2} \mathrm{Cp}_{2}(\mathrm{CO})(\mathrm{NCPh})(\mu-\mathrm{CO})\{\mu-\mathrm{CN}(\mathrm{Me})(\mathrm{Cy})\}\right] \mathrm{CF}_{3} \mathrm{SO}_{3},(4) \mathrm{CF}_{3} \mathrm{SO}_{3}$}

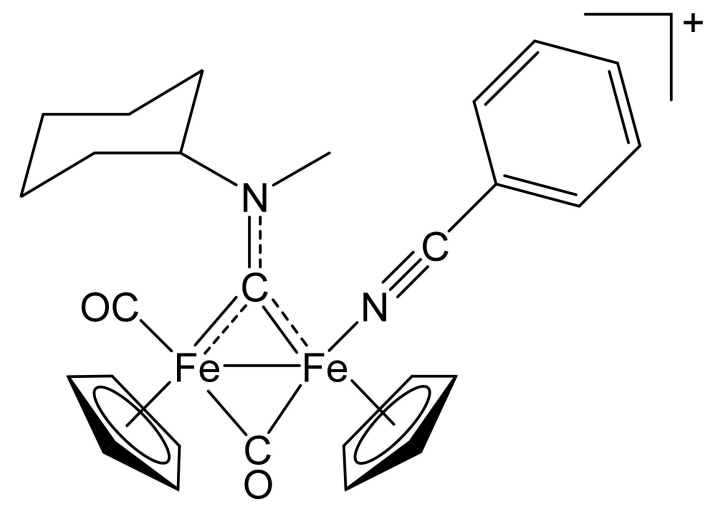

Figure 9. Structure of the cation of $(4) \mathrm{CF}_{3} \mathrm{SO}_{3}$.

From (1a) $\mathrm{CF}_{3} \mathrm{SO}_{3}(100 \mathrm{mg}, 0.167 \mathrm{mmol})$ and benzonitrile $(60 \mu \mathrm{L}, 0.58 \mathrm{mmol})$. Palebrown solid, yield $93 \mathrm{mg}(80 \%)$. Anal. calcd. for $\mathrm{C}_{28} \mathrm{H}_{29} \mathrm{~F}_{3} \mathrm{Fe}_{2} \mathrm{~N}_{2} \mathrm{O}_{5} \mathrm{~S}: \mathrm{C}, 49.88 ; \mathrm{H}, 4.34 ; \mathrm{N}$, 
4.15; S, 4.75. Found: $\mathrm{C}, 49.79 ; \mathrm{H}, 4.38 ; \mathrm{N}, 4.19 ; \mathrm{S}, 4.83$. IR (solid): $\tilde{\mathrm{v}} / \mathrm{cm}^{-1}=2238 \mathrm{w}(\mathrm{C} \equiv \mathrm{N})$, 1965 vs $(\mathrm{CO}), 1799$ vs $(\mu-\mathrm{CO}), 1540 \mathrm{~m}(\mu-\mathrm{CN}) . \mathrm{IR}\left(\mathrm{CH}_{2} \mathrm{Cl}_{2}\right): \tilde{v} / \mathrm{cm}^{-1}=2238 \mathrm{w}(\mathrm{C} \equiv \mathrm{N})$, 1984 vs $(\mathrm{CO}), 1820 \mathrm{~s}(\mu-\mathrm{CO}), 1560 \mathrm{w}(\mu-\mathrm{CN}) .{ }^{1} \mathrm{H}$ NMR $\left(\right.$ acetone- $\left._{6}\right): \delta / \mathrm{ppm}=7.66-7.40(\mathrm{~m}$, $5 \mathrm{H}, \mathrm{Ph}) ; 5.84,5.0^{*}\left(\mathrm{t}, J=11.6 \mathrm{~Hz}, 1 \mathrm{H}, \mathrm{CH}^{\mathrm{Cy}}\right) ; 5.28,5.24,5.17,5.13$ (s, $\left.10 \mathrm{H}, \mathrm{Cp}\right) ; 4.59,4.23$ (s, $3 \mathrm{H}, \mathrm{NMe}) ; 2.76,2.61,2.35-2.22,1.91-1.29\left(\mathrm{~m}, 10 \mathrm{H}, \mathrm{CH}_{2}{ }^{\mathrm{Cy}}\right)$. ${ }^{*}$ Hidden by Cp resonances. ${ }^{13} \mathrm{C}\left\{{ }^{1} \mathrm{H}\right\}$ NMR (acetone- $\left.\mathrm{d}_{6}\right): \delta / \mathrm{ppm}=330.0,329.7(\mu-\mathrm{CN}) ; 266.0,265.8(\mu-\mathrm{CO}) ; 213.3,212.4$ (CO); 134.9, 134.8, 133.2, 133.1, 130.5, 130.4, 111.4, $111.3(\mathrm{Ph}) ; 131.6,131.2(\mathrm{C} \equiv \mathrm{N}) ; 89.9,89.8$, 88.4, 88.3 (Cp); 78.6, $78.1\left(\mathrm{CH}^{\mathrm{Cy}}\right)$; 46.3, 45.5 (NMe); 33.0, 32.0, 31.7, 31.5, 30.8, 26.4, 26.3, 26.2, $25.9\left(\mathrm{CH}_{2} \mathrm{Cy}\right)$. Isomer ratio $(\mathrm{E} / \mathrm{Z})=54: 46$.

$\left[\mathrm{Fe}_{2} \mathrm{Cp}_{2}(\mathrm{CO})\left\{\mathrm{NC}\left(4-\mathrm{C}_{6} \mathrm{H}_{4} \mathrm{NMe}_{2}\right)\right\}(\mu-\mathrm{CO})\{\mu-\mathrm{CN}(\mathrm{Me})(\mathrm{Cy})\}\right] \mathrm{CF}_{3} \mathrm{SO}_{3},(5) \mathrm{CF}_{3} \mathrm{SO}_{3}$

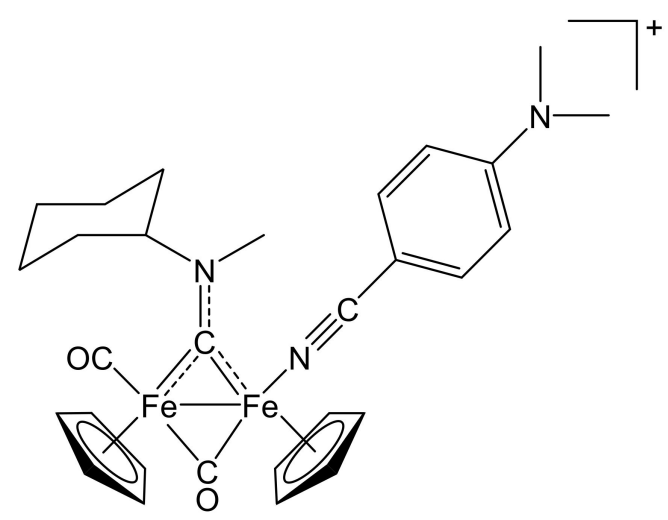

Figure 10. Structure of the cation of $(5) \mathrm{CF}_{3} \mathrm{SO}_{3}$.

From (1a) $\mathrm{CF}_{3} \mathrm{SO}_{3}(100 \mathrm{mg}, 0.167 \mathrm{mmol})$ and 4-dimethylaminobenzonitrile $(85 \mathrm{mg}$, $0.58 \mathrm{mmol}$ ). Brown solid, yield $100 \mathrm{mg}(83 \%)$. X-ray quality crystals of ${ }^{(5)} \mathbf{C F}_{3} \mathbf{S O}_{3}$ were obtained from a $\mathrm{CH}_{2} \mathrm{Cl}_{2}$ solution layered with pentane and settled aside at $-20^{\circ} \mathrm{C}$. Anal. calcd. for $\mathrm{C}_{30} \mathrm{H}_{34} \mathrm{~F}_{3} \mathrm{Fe}_{2} \mathrm{~N}_{3} \mathrm{O}_{5} \mathrm{~S}$ : C, 50.23; $\mathrm{H}, 4.78 ; \mathrm{N}, 5.86 ; \mathrm{S}$, 4.47. Found: $\mathrm{C}, 50.29 ; \mathrm{H}, 4.75 ; \mathrm{N}$, 5.07; S, 4.37. IR (solid state): $\tilde{v} / \mathrm{cm}^{-1}=2227 \mathrm{w}(\mathrm{C} \equiv \mathrm{N}), 1964 \mathrm{vs}(\mathrm{CO}), 1798 \mathrm{~s}(\mu-\mathrm{CO}), 1529 \mathrm{~m}$ $(\mu-\mathrm{CN})$. IR $\left(\mathrm{CH}_{2} \mathrm{Cl}_{2}\right): \tilde{v} / \mathrm{cm}^{-1}=2227 \mathrm{vw}(\mathrm{C} \equiv \mathrm{N}), 1985$ vs $(\mathrm{CO}), 1819 \mathrm{~s}(\mu-\mathrm{CO}), 1561 \mathrm{w}$ $(\mu-\mathrm{CN}) .{ }^{1} \mathrm{H}$ NMR $\left(\right.$ acetone- $\left._{6}\right): \delta / \mathrm{ppm}=7.13,6.97,6.63\left(\mathrm{~m}, 4 \mathrm{H}, \mathrm{C}_{6} \mathrm{H}_{4}\right) ; 5.84,5.0 *(\mathrm{~m}, 1 \mathrm{H}$, $\mathrm{CH}^{\mathrm{Cy}}$ ); 5.24, 5.20, 5.10, 5.06 (s, $\left.10 \mathrm{H}, \mathrm{Cp}\right) ; 4.58,4.21$ (s, $\left.3 \mathrm{H}, \mathrm{NMe}\right) ; 3.00,2.86$ (s, $6 \mathrm{H}, \mathrm{NMe}_{2}$ ); 2.77, 2.62, 2.34-2.22, 1.89-1.36 $\left(\mathrm{m}, 10 \mathrm{H}, \mathrm{CH}_{2}{ }^{\mathrm{Cy}}\right)$. ${ }^{*}$ Hidden by $\mathrm{Cp}$ resonances. ${ }^{13} \mathrm{C}\left\{{ }^{1} \mathrm{H}\right\} \mathrm{NMR}$ $\left(\right.$ acetone- $\left.\mathrm{d}_{6}\right): \delta / \mathrm{ppm}=330.9,330.4(\mu-\mathrm{CN}) ; 266.6,266.3(\mu-\mathrm{CO}) ; 213.4,212.6(\mathrm{CO}) ; 154.2$, $134.9,134.3,112.4,112.3,95.4,95.3\left(\mathrm{C}_{6} \mathrm{H}_{4}\right) ; 133.9,133.4,(\mathrm{C} \equiv \mathrm{N}) ; 89.7,89.6,88.1,88.0(\mathrm{Cp})$; 78.4, 77.9 (CHCy); 46.1, 45.3 (NMe); $39.9\left(\mathrm{NMe}_{2}\right) ; 32.9,32.1,31.7,31.5,30.8,26.4,26.3,26.1$, $25.9\left(\mathrm{CH}_{2}{ }^{\mathrm{Cy}}\right)$. Isomer ratio $(\mathrm{E} / \mathrm{Z})=53: 47$.

$\left[\mathrm{Fe}_{2} \mathrm{Cp}_{2}(\mathrm{CO})\left\{\mathrm{NC}\left(4-\mathrm{C}_{6} \mathrm{H}_{4} \mathrm{NO}_{2}\right)\right\}(\mu-\mathrm{CO})\{\mu-\mathrm{CN}(\mathrm{Me})(\mathrm{Cy})\}\right] \mathrm{CF}_{3} \mathrm{SO}_{3},(\mathbf{6}) \mathrm{CF}_{3} \mathrm{SO}_{3}$

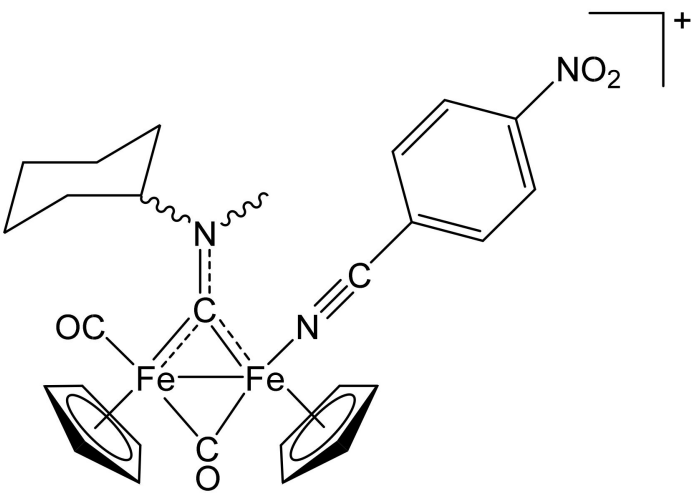

Figure 11. Structure of the cation of $(6) \mathrm{CF}_{3} \mathrm{SO}_{3}$. 
From (1a) $\mathrm{CF}_{3} \mathrm{SO}_{3}(100 \mathrm{mg}, 0.167 \mathrm{mmol})$ and 4-nitrobenzonitrile $(87 \mathrm{mg}, 0.58 \mathrm{mmol})$. Dark-red solid, yield $85 \mathrm{mg}(71 \%)$. Anal. calcd. for $\mathrm{C}_{28} \mathrm{H}_{28} \mathrm{~F}_{3} \mathrm{Fe}_{2} \mathrm{~N}_{3} \mathrm{O}_{7} \mathrm{~S}: \mathrm{C}, 46.76 ; \mathrm{H}, 3.92$; $\mathrm{N}, 5.84 ; \mathrm{S}, 4.46$. Found: C, 46.62; H, 3.98; N, 5.79; S, 4.53. IR (solid state): $\tilde{v} / \mathrm{cm}^{-1}=2230 \mathrm{w}$ $(\mathrm{C} \equiv \mathrm{N}), 1966$ vs $(\mathrm{CO}), 1801 \mathrm{~s}(\mu-\mathrm{CO}), 1526 \mathrm{~m}(\mu-\mathrm{CN}) . \mathrm{IR}\left(\mathrm{CH}_{2} \mathrm{Cl}_{2}\right): \tilde{\mathrm{v}} / \mathrm{cm}^{-1}=2230 \mathrm{vw}$ $(\mathrm{C} \equiv \mathrm{N}), 1982$ vs $(\mathrm{CO}), 1821 \mathrm{~s}(\mu-\mathrm{CO}), 1561 \mathrm{~s}(\mu-\mathrm{CN}) .{ }^{1} \mathrm{H}$ NMR (acetone- $\left.\mathrm{d}_{6}\right)$ cis-isomers: $\delta / \mathrm{ppm}=8.31,7.74\left(\mathrm{~m}, 4 \mathrm{H}, \mathrm{C}_{6} \mathrm{H}_{4}\right) ; 5.82,5.0 *\left(\mathrm{~m}, 1 \mathrm{H}, \mathrm{CH}^{\mathrm{Cy}}\right) ; 5.33,5.29,5.23,5.19(\mathrm{~s}$, $10 \mathrm{H}, \mathrm{Cp}) ; 4.60,4.26$ (s, $3 \mathrm{H}, \mathrm{NMe}) ; 2.78,2.61,2.35-1.42\left(\mathrm{~m}, 10 \mathrm{H}, \mathrm{CH}_{2}{ }^{\mathrm{Cy}}\right)$. * Hidden by Cp resonances. ${ }^{1} \mathrm{H}$ NMR (acetone- $\left.\mathrm{d}_{6}\right)$ trans-isomers: $\delta / \mathrm{ppm}=8.48,8.15\left(\mathrm{~m}, 4 \mathrm{H}, \mathrm{C}_{6} \mathrm{H}_{4}\right)$; 4.92, 4.89, 4.69, 4.66 (s, $10 \mathrm{H}, \mathrm{Cp}) ; 4.55,4.14$ (s, $\left.3 \mathrm{H}, \mathrm{NMe}) .{ }^{13} \mathrm{C}^{1}{ }^{1} \mathrm{H}\right\}$ NMR (acetone- $\mathrm{d}_{6}$ ): $\delta / \mathrm{ppm}=329.2,329.0(\mu-\mathrm{CN}) ; 265.4,265.2(\mu-\mathrm{CO}) ; 213.1,212.3(\mathrm{CO}) ; 151.1,134.9,134.8$, 125.3, 125.2, 117.1, $116.9\left(\mathrm{C}_{6} \mathrm{H}_{4}\right) ; 129.6,129.2(\mathrm{C} \equiv \mathrm{N}) ; 90.1,89.9,88.8,88.6(\mathrm{Cp}) ; 78.7,78.2$ $\left(\mathrm{CH}^{\mathrm{Cy}}\right) ; 46.4,45.6$ (NMe); 35.0, 33.1, 32.0, 31.6, 31.5, 30.8, 26.3, 26.0, $\left.25.8\left(\mathrm{CH}_{2}{ }^{\mathrm{Cy}}\right) .{ }^{13} \mathrm{C}^{1}{ }^{1} \mathrm{H}\right\}$ NMR (acetone- $\mathrm{d}_{6}$ ) trans-isomers: $\delta / \mathrm{ppm}=89.6,89.4,87.9,87.8(\mathrm{Cp})$. Isomer ratio (cis$\mathrm{E} /$ cis-Z $)=56: 44$. Isomer ratio $($ trans- $\mathrm{E} /$ trans $-Z)=50: 50$. Isomer ratio $($ cis $/$ trans $)=92: 8$.

$\left[\mathrm{Fe}_{2} \mathrm{Cp}_{2}(\mathrm{CO})\left\{\mathrm{NC}\left(4-\mathrm{C}_{6} \mathrm{H}_{4} \mathrm{~F}\right)\right\}(\mu-\mathrm{CO})\{\mu-\mathrm{CN}(\mathrm{Me})(\mathrm{Cy})\}\right] \mathrm{CF}_{3} \mathrm{SO}_{3},(7) \mathrm{CF}_{3} \mathrm{SO}_{3}$

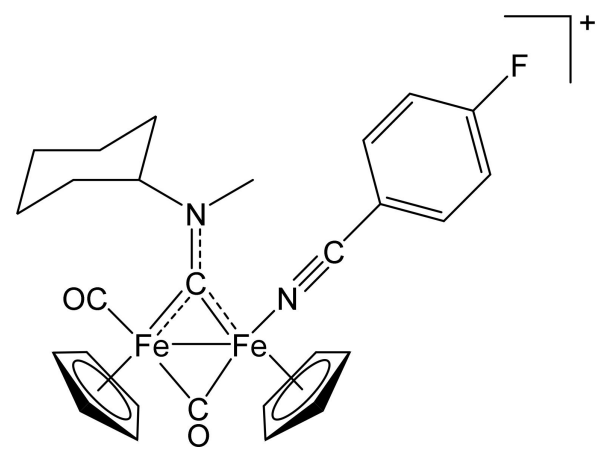

Figure 12. Structure of the cation of $(7) \mathrm{CF}_{3} \mathrm{SO}_{3}$.

From (1a) $\mathrm{CF}_{3} \mathrm{SO}_{3}(100 \mathrm{mg}, 0.167 \mathrm{mmol})$ and 4-fluorobenzonitrile $(71 \mu \mathrm{L}, 0.58 \mathrm{mmol})$. Brown solid, yield $81 \mathrm{mg}(70 \%)$. Anal. calcd. for $\mathrm{C}_{28} \mathrm{H}_{28} \mathrm{~F}_{4} \mathrm{Fe}_{2} \mathrm{~N}_{2} \mathrm{O}_{5} \mathrm{~S}: \mathrm{C}, 48.58 ; \mathrm{H}, 4.08 ; \mathrm{N}$, 4.05; S, 4.63. Found: C, 48.38; H, 4.12; N, 4.07; S, 4.67. IR (solid state): $\tilde{v} / \mathrm{cm}^{-1}=2240 \mathrm{w}$ $(\mathrm{C} \equiv \mathrm{N}), 1967 \mathrm{vs}(\mathrm{CO}), 1800 \mathrm{~s}(\mu-\mathrm{CO}), 1540 \mathrm{~m}(\mu-\mathrm{CN}) . \mathrm{IR}\left(\mathrm{CH}_{2} \mathrm{Cl}_{2}\right): \widetilde{v} / \mathrm{cm}^{-1}=2240 \mathrm{w}(\mathrm{C} \equiv \mathrm{N})$, 1983 vs $(\mathrm{CO}), 1819 \mathrm{~s}(\mu-\mathrm{CO}), 1559 \mathrm{~m}(\mu \mathrm{CN}) .{ }^{1} \mathrm{H}$ NMR $\left(\right.$ acetone- $\left._{6}\right): \delta / \mathrm{ppm}=7.52,7.29$ $\left(\mathrm{m}, 4 \mathrm{H}, \mathrm{C}_{6} \mathrm{H}_{4}\right) ; 5.83,5.0$ * (m, $\left.1 \mathrm{H}, \mathrm{CH}^{\mathrm{Cy}}\right) ; 5.28,5.24,5.16,5.12$ (s, $\left.10 \mathrm{H}, \mathrm{Cp}\right) ; 4.59,4.24$ (s, $3 \mathrm{H}, \mathrm{NMe}) ; 2.73,2.61,2.31-2.20,1.88-1.36\left(\mathrm{~m}, 10 \mathrm{H}, \mathrm{CH}_{2} \mathrm{Cy}\right) .{ }^{*}$ Hidden by Cp resonances. ${ }^{13} \mathrm{C}\left\{{ }^{1} \mathrm{H}\right\}$ NMR (acetone- $\left.\mathrm{d}_{6}\right): \delta / \mathrm{ppm}=329.9,329.7(\mu-\mathrm{CN}) ; 265.9,265.7(\mu-\mathrm{CO}) ; 212.4,212.3$ (CO); 166.2, 136.4, 136.2, 118.4, 117.9, 107.9, $107.8\left(\mathrm{~d}, \mathrm{C}_{6} \mathrm{H}_{4}\right) ; 130.7,130.4(\mathrm{C} \equiv \mathrm{N}) ; 89.9,89.7$, 88.4, 88.3 (Cp); 78.6, $78.1\left(\mathrm{CH}^{\mathrm{Cy}}\right)$; 46.3, 45.5 (NMe); 33.0, 32.0, 31.6, 31.5 26.3, 26.2, 26.1, 25.8 $\left(\mathrm{CH}_{2}{ }^{\mathrm{Cy}}\right) .{ }^{19} \mathrm{~F}\left\{{ }^{1} \mathrm{H}\right\}$ NMR (acetone- $\left.\mathrm{d}_{6}\right):-102.0,-102.2(\mathrm{~s})$. Isomer ratio $(\mathrm{E} / \mathrm{Z})=50: 50$.

$\left[\mathrm{Fe}_{2} \mathrm{Cp}_{2}(\mathrm{CO})\left(\mathrm{NH}=\mathrm{CPh}_{2}\right)(\mu-\mathrm{CO})\{\mu-\mathrm{CN}(\mathrm{Me})(\mathrm{Cy})\}\right] \mathrm{CF}_{3} \mathrm{SO}_{3},(\mathbf{8}) \mathrm{CF}_{3} \mathrm{SO}_{3}$

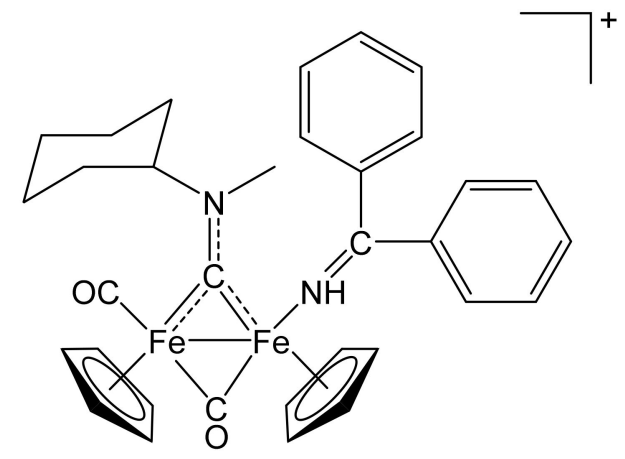

Figure 13. Structure of the cation of $(8) \mathrm{CF}_{3} \mathrm{SO}_{3}$. 
From (1a) $\mathrm{CF}_{3} \mathrm{SO}_{3}(100 \mathrm{mg}, 0.167 \mathrm{mmol})$ and benzophenone imine $(97 \mu \mathrm{L}, 0.58 \mathrm{mmol})$. Dark-red solid, yield $78 \mathrm{mg}(62 \%)$. Anal. calcd. for $\mathrm{C}_{34} \mathrm{H}_{35} \mathrm{~F}_{3} \mathrm{Fe}_{2} \mathrm{~N}_{2} \mathrm{O}_{5} \mathrm{~S}: \mathrm{C}, 54.28 ; \mathrm{H}, 4.69 ; \mathrm{N}$, 3.72; S, 4.26. Found: C, 54.19; H, 4.58; N, 3.69; S, 4.18. IR (solid state): $\tilde{v} / \mathrm{cm}^{-1}=1955$ vs. (CO), $1792 \mathrm{~s}(\mu-\mathrm{CO}), 1537 \mathrm{~m}(\mu-\mathrm{CN}), 1532 \mathrm{w}(\mathrm{C}=\mathrm{N}) . \mathrm{IR}\left(\mathrm{CH}_{2} \mathrm{Cl}_{2}\right): \tilde{v} / \mathrm{cm}^{-1}=1974 \mathrm{vs}(\mathrm{CO})$, $1810 \mathrm{~s}(\mu-\mathrm{CO}), 1558 \mathrm{vw}(\mu-\mathrm{CN}), 1531 \mathrm{w}(\mathrm{C}=\mathrm{NH}) .{ }^{1} \mathrm{H}$ NMR $\left(\right.$ acetone- $\left._{6}\right): \delta / \mathrm{ppm}=7.75-7.35$, 6.95-6.81 (m, $10 \mathrm{H}, \mathrm{Ph}) ; 6.60,6.38(\mathrm{~s}, 1 \mathrm{H}, \mathrm{NH}) ; 6.09,4.8 *\left(\mathrm{~m}, 1 \mathrm{H}, \mathrm{CH}^{\mathrm{Cy}}\right) ; 5.16,4.84,4.78$ (s, $10 \mathrm{H}, \mathrm{Cp}) ; 4.74,4.42$ (s, $3 \mathrm{H}, \mathrm{NMe}) ; 2.68,2.50-2.30,1.89-1.41\left(\mathrm{~m}, 10 \mathrm{H}, \mathrm{CH}_{2}{ }^{\mathrm{Cy}}\right) .{ }^{*}$ Hidden by Cp resonances. ${ }^{13} \mathrm{C}\left\{{ }^{1} \mathrm{H}\right\}$ NMR (acetone- $\left.\mathrm{d}_{6}\right): \delta / \mathrm{ppm}=334.5(\mu-\mathrm{CN}) ; 266.8(\mu-\mathrm{CO}) ; 214.5$ (CO); 192.7 (C=NH); 139.8, 137.2, 132.9, 132.8, 131.9, 131.8, 130.4, 130.2, 129.8, 129.7, 129.5, 129.4, 129.1, 127.7, $126.1(\mathrm{Ph}) ; 90.3,90.0,88.0,87.7(\mathrm{Cp}) ; 79.1,76.6\left(\mathrm{CH}^{\mathrm{Cy}}\right) ; 47.6,45.7(\mathrm{NMe})$; $33.6,33.2,31.8,31.7,30.8,26.4,26.3,25.9\left(\mathrm{CH}_{2}{ }^{\mathrm{Cy}}\right)$. Isomer ratio $(\mathrm{E} / \mathrm{Z})=62: 38$.

$\left[\mathrm{Fe}_{2} \mathrm{Cp}_{2}(\mathrm{CO})\left(\mathrm{NH}_{2} \mathrm{Et}\right)(\mu-\mathrm{CO})\{\mu-\mathrm{CN}(\mathrm{Me})(\mathrm{Cy})\}\right] \mathrm{CF}_{3} \mathrm{SO}_{3},(9) \mathrm{CF}_{3} \mathrm{SO}_{3}$

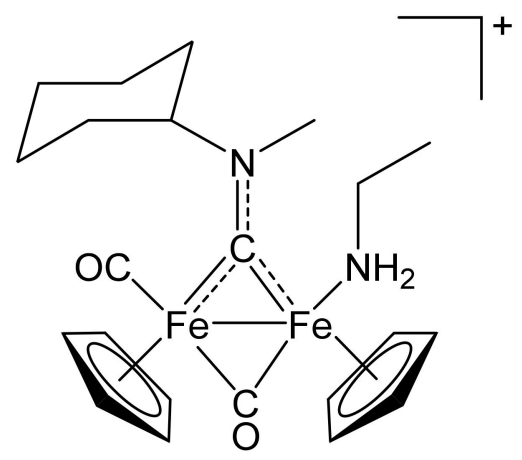

Figure 14. Structure of the cation of $(9) \mathrm{CF}_{3} \mathrm{SO}_{3}$.

From (1a) $\mathrm{CF}_{3} \mathrm{SO}_{3}(100 \mathrm{mg}, 0.167 \mathrm{mmol}$ ) and ethylamine (large excess of gas bubbled into the solution). Brown solid, yield $60 \mathrm{mg}(58 \%)$. Anal. calcd. for $\mathrm{C}_{23} \mathrm{H}_{31} \mathrm{~F}_{3} \mathrm{Fe}_{2} \mathrm{~N}_{2} \mathrm{O}_{5} \mathrm{~S}$ : C, 44.83; H, 5.07; N, 4.55; S, 5.20. Found: C, 44.93; H, 5.02; N, 4.62; S, 5.24. IR (solid state): $\tilde{v} / \mathrm{cm}^{-1}=1944 \mathrm{vs}(\mathrm{CO}), 1780 \mathrm{~s}(\mu-\mathrm{CO})$. IR $\left(\mathrm{CH}_{2} \mathrm{Cl}_{2}\right): \tilde{v} / \mathrm{cm}^{-1}=1965 \mathrm{vs}(\mathrm{CO}), 1800 \mathrm{~s}(\mu-\mathrm{CO})$, $1560 \mathrm{vw}(\mu-\mathrm{CN}) .{ }^{1} \mathrm{H}$ NMR (acetone- $\left.\mathrm{d}_{6}\right): \delta / \mathrm{ppm}=5.85,5.0 *\left(\mathrm{~m}, 1 \mathrm{H}, \mathrm{CH}^{\mathrm{Cy}}\right) ; 5.11,5.10,5.01$, 5.00 (s, $10 \mathrm{H}, \mathrm{Cp}$ ); 4.54, 4.21 (s, $3 \mathrm{H}, \mathrm{NMe}$ ); 3.06-2.89 (m, $2 \mathrm{H}, \mathrm{CH}_{2}{ }^{\text {amine }}$ ); 2.63, 2.54, 2.35-2.21, 1.97-1.40 (m, $\left.10 \mathrm{H}, \mathrm{CH}_{2}{ }^{\mathrm{Cy}}\right) ; 0.73\left(\mathrm{~m}, 3 \mathrm{H}, \mathrm{CH}_{3}{ }^{\text {amine }}\right) ;-1.80,-1.89\left(\mathrm{~s}, \mathrm{NH}_{2}\right)$. * Hidden by Cp resonances. ${ }^{13} \mathrm{C}\left\{{ }^{1} \mathrm{H}\right\}$ NMR (acetone- $\left.\mathrm{d}_{6}\right): \delta / \mathrm{ppm}=331.9,331.7(\mu-\mathrm{CN}) ; 270.4,269.6$ ( $\mu-\mathrm{CO}) ; 215.2,214.7(\mathrm{CO}) ; 89.7,89.5,87.8,87.5(\mathrm{Cp}) ; 78.6,75.7\left(\mathrm{CH}^{\mathrm{Cy}}\right) ; 47.0,45.3(\mathrm{NMe})$; 44.0, $43.9\left(\mathrm{CH}_{2}\right.$ amine $) ; 35.1,33.1,32.7,31.8,30.8,26.4,26.3,26.1,26.0,25.7\left(\mathrm{CH}_{2}{ }^{\mathrm{Cy}}\right) ; 17.4,17.3$ $\left(\mathrm{CH}_{3}{ }^{\text {amine }}\right)$. Isomer ratio $(\mathrm{E} / \mathrm{Z})=56: 44$.

$\left[\mathrm{Fe}_{2} \mathrm{Cp}_{2}(\mathrm{CO})\left\{\mathrm{NC}\left(4-\mathrm{C}_{6} \mathrm{H}_{4} \mathrm{NO}_{2}\right)\right\}(\mu-\mathrm{CO})\left\{\mu-\mathrm{CN}(\mathrm{Me})\left(2,6-\mathrm{C}_{6} \mathrm{H}_{3} \mathrm{MeCl}\right)\right\}\right] \mathrm{CF}_{3} \mathrm{SO}_{3},(\mathbf{1 0}) \mathrm{CF}_{3} \mathrm{SO}_{3}$

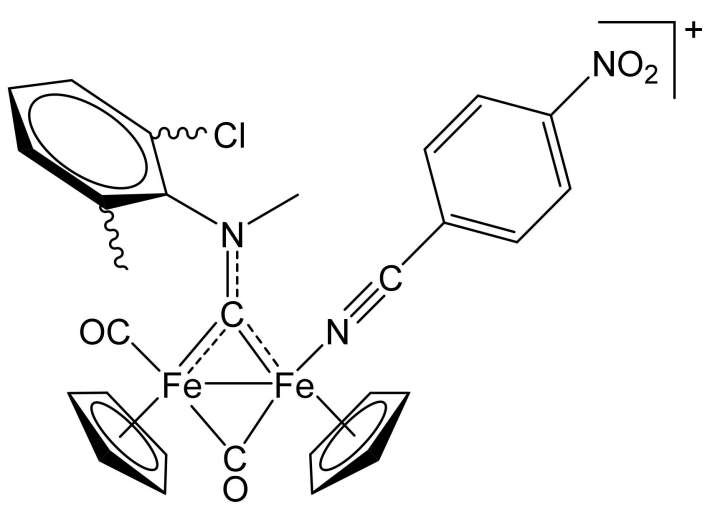

Figure 15. Structure of the cation of $(10) \mathrm{CF}_{3} \mathrm{SO}_{3}$. 
From (1b) $\mathrm{CF}_{3} \mathrm{SO}_{3}(100 \mathrm{mg}, 0.156 \mathrm{mmol})$ and 4-nitrobenzonitrile $(81 \mathrm{mg}, 0.55 \mathrm{mmol})$. Red solid, yield $76 \mathrm{mg}(64 \%)$. Anal. calcd. for $\mathrm{C}_{29} \mathrm{H}_{23} \mathrm{ClF}_{3} \mathrm{Fe}_{2} \mathrm{~N}_{3} \mathrm{O}_{7} \mathrm{~S}: \mathrm{C}, 45.73 ; \mathrm{H}, 3.04 ; \mathrm{N}$, 5.52; S, 4.21. Found: C, 45.67; H, 2.98; N, 5.49; S, 4.15. IR (solid state): $\tilde{v} / \mathrm{cm}^{-1}=2235 \mathrm{w}$ $(\mathrm{C} \equiv \mathrm{N}), 1975$ vs $(\mathrm{CO}), 1810 \mathrm{~s}(\mu-\mathrm{CO}), 1514(\mu-\mathrm{CN}) . \mathrm{IR}\left(\mathrm{CH}_{2} \mathrm{Cl}_{2}\right)$ : $\tilde{v} / \mathrm{cm}^{-1}=1988 \mathrm{vs}(\mathrm{CO})$, $1825 \mathrm{~s}(\mu-\mathrm{CO}), 1560 \mathrm{~s}(\mu-\mathrm{CN}) .{ }^{1} \mathrm{H}$ NMR $\left(\right.$ acetone- $\left.\mathrm{d}_{6}\right): \delta / \mathrm{ppm}=8.48-8.15,7.86-7.61(\mathrm{~m}, 7 \mathrm{H}$, arom $\mathrm{CH}) ; 5.49,5.40,5.00,4.99,4.87,4.84,4.75,4.72$ (s, $10 \mathrm{H}, \mathrm{Cp}) ; 3.64,3.42(\mathrm{~m}, 3 \mathrm{H}, \mathrm{NMe})$; 2.44, 2.33, 2.29, $2.23\left(\mathrm{~s}, 3 \mathrm{H}, \mathrm{C}_{6} \mathrm{H}_{3} \mathrm{Me}\right) .{ }^{13} \mathrm{C}\left\{{ }^{1} \mathrm{H}\right\} \mathrm{NMR}$ (acetone- $\left.\mathrm{d}_{6}\right): \delta / \mathrm{ppm}=342.2,341.1$, $341.8,341.0(\mu-\mathrm{CN}) ; 263.9,263.7,263.3,262.7$ ( $\mu-\mathrm{CO}) ; 212.9,212.4,212,1,121.0(\mathrm{CO}) ; 152.6$, 151.2, 147.2, 147.1, 146.9, 146.6, 138.3, 138.2, 138.0, 137.6, 136.5, 135.1, 135.0, 134.9, 134.8, $132.5,131.4,126.0,125.3,117.1,117.0\left(\mathrm{C}_{6} \mathrm{H}_{4}+\mathrm{C}_{6} \mathrm{H}_{3}\right) ; 130.0,129.9,129.2,129.1(\mathrm{C} \equiv \mathrm{N}) ; 90.6$, 89.7, 89.5, 89.4, 88.5, 88.4 (Cp); 55.7, 55.5, 54.6, 54.3 (NMe); 19.3, 19.1, 18.4, $18.1\left(\mathrm{C}_{6} \mathrm{H}_{3} \mathrm{Me}\right)$. Isomer ratio $=70$ (cis-E, two conformers): 30 (cis-Z, two conformers).

\subsubsection{Synthesis and Characterization of $\left[\mathrm{Fe}_{2} \mathrm{Cp}_{2}(\mathrm{CO})(\mathrm{NCMe})(\mu-\mathrm{CO})\{\mu-\mathrm{CN}(\mathrm{Me})\right.$} $\left.\left.\left(\mathrm{CH}_{2} \mathrm{CH}=\mathrm{CH}_{2}\right)\right\}\right] \mathrm{CF}_{3} \mathrm{SO}_{3},(11) \mathrm{CF}_{3} \mathrm{SO}_{3}$

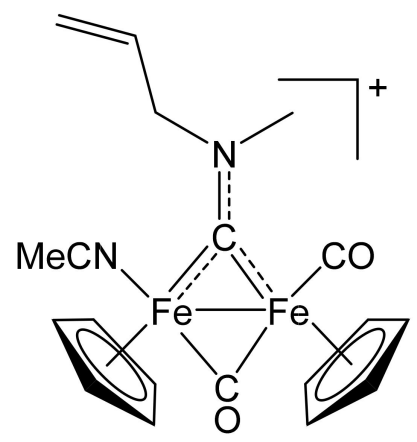

Figure 16. Structure of the cation of $(11) \mathrm{CF}_{3} \mathrm{SO}_{3}$.

The title compound was prepared by a procedure analogous to that described for the synthesis of (2) $\mathrm{CF}_{3} \mathrm{SO}_{3}$, from (1c) $\mathrm{CF}_{3} \mathrm{SO}_{3}(240 \mathrm{mg}, 0.431 \mathrm{mmol})$ and $\mathrm{Me}_{3} \mathrm{NO} \cdot 2 \mathrm{H}_{2} \mathrm{O}$ (53 mg, $0.47 \mathrm{mmol}$ ) in acetonitrile $(7 \mathrm{~mL})$. Brown solid, yield $182 \mathrm{mg}(77 \%)$. X-ray quality crystals of $\mathbf{( 1 1 )} \mathrm{CF}_{3} \mathrm{SO}_{3}$ were obtained from a MeCN solution layered with $\mathrm{Et}_{2} \mathrm{O}$ and settled aside at $-20{ }^{\circ} \mathrm{C}$. Anal. calcd. for $\mathrm{C}_{20} \mathrm{H}_{21} \mathrm{~F}_{3} \mathrm{Fe}_{2} \mathrm{~N}_{2} \mathrm{O}_{5} \mathrm{~S}$ : C, 42.13; $\mathrm{H}, 3.71 ; \mathrm{N}, 4.91 ; \mathrm{S}, 5.62$. Found: $\mathrm{C}, 42.18 ; \mathrm{H}, 3.65 ; \mathrm{N}, 4.88 ; \mathrm{S}, 5.68$. IR (solid): $\tilde{\mathrm{v}} / \mathrm{cm}^{-1}=2277 \mathrm{vw}(\mathrm{C} \equiv \mathrm{N}), 1956 \mathrm{vs}(\mathrm{CO})$, $1803 \mathrm{~s}(\mu-\mathrm{CO}), 1571(\mu-\mathrm{CN})$. IR $\left(\mathrm{CH}_{2} \mathrm{Cl}_{2}\right): \tilde{\nu} / \mathrm{cm}^{-1}=1987 \mathrm{vs}(\mathrm{CO}), 1818 \mathrm{~s}(\mu-\mathrm{CO}), 1568 \mathrm{w}$ $(\mu-\mathrm{CO}) .{ }^{1} \mathrm{H}$ NMR (acetone- $\left.\mathrm{d}_{6}\right): \delta / \mathrm{ppm}=6.42(\mathrm{~m}, 1 \mathrm{H}, \mathrm{CH}=) ; 5.86,5.69\left(\mathrm{dd}, 2 \mathrm{H},=\mathrm{CH}_{2}\right)$; $5.55\left(\mathrm{~m}, 2 \mathrm{H}, \mathrm{NCH}_{2}\right) ; 5.23,5.19,5.04,4.99$ (s, $\left.10 \mathrm{H}, \mathrm{Cp}\right) ; 4.63$, 4.30 (s, $\left.3 \mathrm{H}, \mathrm{NMe}\right) ; 2.07$ (s, $3 \mathrm{H}$, $\mathrm{NCMe}){ }^{13}{ }^{1}\left\{{ }^{1} \mathrm{H}\right\}$ NMR (acetone- $\left.\mathrm{d}_{6}\right): \delta / \mathrm{ppm}=333.4(\mu-\mathrm{CN}) ; 266.3(\mu-\mathrm{CO}) ; 212.3(\mathrm{CO}) ; 134.0$, $133.2(\mathrm{CH}=) ; 132.1(\mathrm{C} \equiv \mathrm{N}) ; 119.9,119.5\left(=\mathrm{CH}_{2}\right) ; 89.5,89.4,87.7,87.5(\mathrm{Cp}) ; 70.2,69.6\left(\mathrm{NCH}_{2}\right)$; $51.3(\mathrm{NMe}) ; 3.7(\mathrm{NCMe})$. Isomer ratio $(\mathrm{Z} / \mathrm{E})=87: 13$.

4.2.4. Synthesis and Characterization of $\left[\mathrm{Fe}_{2} \mathrm{Cp}_{2}(\mathrm{CO})(\mathrm{NCMe})(\mu-\mathrm{CO})\{\mu-\mathrm{CN}(\mathrm{Me})\right.$ $\left.\left.\left(4-\mathrm{C}_{6} \mathrm{H}_{4} \mathrm{OMe}\right)\right\}\right] \mathrm{CF}_{3} \mathrm{SO}_{3},(12) \mathrm{CF}_{3} \mathrm{SO}_{3}$

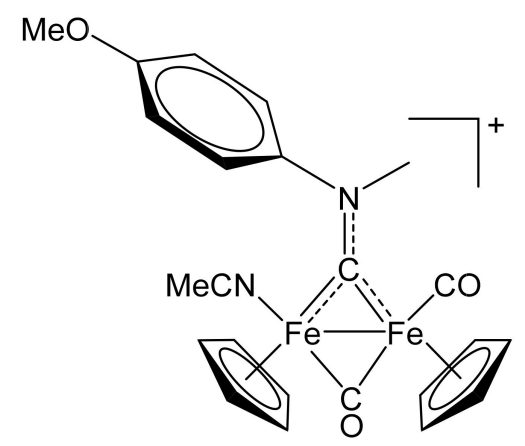

Figure 17. Structure of the cation of $(12) \mathrm{CF}_{3} \mathrm{SO}_{3}$. 
The title compound was prepared by a procedure analogous to that described for the synthesis of (2) $\mathrm{CF}_{3} \mathrm{SO}_{3}$, from (1d) $\mathrm{CF}_{3} \mathrm{SO}_{3}(262 \mathrm{mg}, 0.420 \mathrm{mmol})$ and $\mathrm{Me}_{3} \mathrm{NO} \cdot 2 \mathrm{H}_{2} \mathrm{O}$ (51 mg, $0.46 \mathrm{mmol}$ ) in acetonitrile $(7 \mathrm{~mL})$. Brown solid, yield $200 \mathrm{mg}(75 \%)$. Anal. calcd. for $\mathrm{C}_{24} \mathrm{H}_{23} \mathrm{~F}_{3} \mathrm{Fe}_{2} \mathrm{~N}_{2} \mathrm{O}_{6} \mathrm{~S}: \mathrm{C}, 45.31 ; \mathrm{H}, 3.64 ; \mathrm{N}, 4.40 ; \mathrm{S}, 5.04$. Found: $\mathrm{C}, 45.38 ; \mathrm{H}, 3.69 ; \mathrm{N}, 4.32 ; \mathrm{S}$, 5.09. IR (solid): $\tilde{\nu} / \mathrm{cm}^{-1}=2281 \mathrm{vw}(\mathrm{C} \equiv \mathrm{N}), 1972$ vs $(\mathrm{CO}), 1802 \mathrm{~s}(\mu-\mathrm{CO}), 1505(\mu \mathrm{CN})$. IR $\left(\mathrm{CH}_{2} \mathrm{Cl}_{2}\right): \tilde{v} / \mathrm{cm}^{-1}=1984 \mathrm{vs}(\mathrm{CO}), 1817 \mathrm{~s}(\mu-\mathrm{CO}), 1525 \mathrm{w}(\mu-\mathrm{CN}) .{ }^{1} \mathrm{H}$ NMR (acetone-d $\left.\mathrm{d}_{6}\right):$ $\delta / \mathrm{ppm}=7.88-7.78,7.27\left(\mathrm{~m}, 4 \mathrm{H}, \mathrm{C}_{6} \mathrm{H}_{4}\right) ; 5.32,5.14,4.67,4.46$ (s, $\left.10 \mathrm{H}, \mathrm{Cp}\right) ; 5.01,4.71$ (s, $3 \mathrm{H}, \mathrm{NMe}) ; 3.97$ (s, $3 \mathrm{H}, \mathrm{OMe}) ; 2.19,2.15$ (s, $3 \mathrm{H}, \mathrm{NCMe}) .{ }^{13} \mathrm{C}\left({ }^{1} \mathrm{H}\right\}$ NMR (acetone-d $\mathrm{d}_{6}$ ): $\delta / \mathrm{ppm}=338.2,338.1(\mu-\mathrm{CN}) ; 268.7,266.0(\mu-\mathrm{CO}) ; 213.3,212.4(\mathrm{CO}) ; 160.6,160.5,145.4$, 145.0, 127.9, 127.6, $115.9\left(\mathrm{C}_{6} \mathrm{H}_{4}\right) ; 132.3,132.1(\mathrm{C} \equiv \mathrm{N}) ; 89.9,89.5,88.1,87.6(\mathrm{Cp}) ; 57.3,57.2$ $(\mathrm{NMe}) ; 56.3,56.2(\mathrm{OMe}) ; 3.9,3.8(\mathrm{NCMe})$. Isomer ratio $(\mathrm{Z} / \mathrm{E})=55: 45$.

\subsection{X-ray Crystallography}

Crystal data and collection details for (2) $\mathrm{CF}_{3} \mathrm{SO}_{3},(3) \mathrm{CF}_{3} \mathrm{SO}_{3},(5) \mathrm{CF}_{3} \mathrm{SO}_{3}$ and $(\mathbf{( 1 1}) \mathrm{CF}_{3} \mathrm{SO}_{3}$ are reported in Table 5. Data were recorded on a Bruker APEX II diffractometer equipped with a PHOTON2 detector using Mo-K $\alpha$ radiation. The structures were solved by direct methods and refined by full-matrix least-squares based on all data using $F^{2}$ [78]. Hydrogen atoms were fixed at calculated positions and refined using a riding model. All non-hydrogen atoms were refined with anisotropic displacement parameters. The crystals of $(2) \mathrm{CF}_{3} \mathrm{SO}_{3}$ appeared to be non-merohedrally twinned. The TwinRotMat routine of PLATON [79] was used to determine the twinning matrix and to write the reflection data file (.hkl) containing the twin components. Refinement was performed using the instruction HKLF 5 in SHELXL and one BASF parameter, which refined as 0.262(3).

Table 5. Crystal data and measurement details for $(2) \mathrm{CF}_{3} \mathrm{SO}_{3},(3) \mathrm{CF}_{3} \mathrm{SO}_{3},(5) \mathrm{CF}_{3} \mathrm{SO}_{3}$ and (11) $\mathrm{CF}_{3} \mathrm{SO}_{3}$.

\begin{tabular}{|c|c|c|c|c|}
\hline & (2) $\mathrm{CF}_{3} \mathrm{SO}_{3}$ & (3) $\mathrm{CF}_{3} \mathrm{SO}_{3}$ & (5) $\mathrm{CF}_{3} \mathrm{SO}_{3}$ & $(11) \mathrm{CF}_{3} \mathrm{SO}_{3}$ \\
\hline Formula & $\mathrm{C}_{23} \mathrm{H}_{27} \mathrm{~F}_{3} \mathrm{Fe}_{2} \mathrm{~N}_{2} \mathrm{O}_{5} \mathrm{~S}$ & $\mathrm{C}_{26} \mathrm{H}_{33} \mathrm{~F}_{3} \mathrm{Fe}_{2} \mathrm{~N}_{2} \mathrm{O}_{5} \mathrm{~S}$ & $\mathrm{C}_{30} \mathrm{H}_{34} \mathrm{~F}_{3} \mathrm{Fe}_{2} \mathrm{~N}_{3} \mathrm{O}_{5} \mathrm{~S}$ & $\mathrm{C}_{20} \mathrm{H}_{21} \mathrm{~F}_{3} \mathrm{Fe}_{2} \mathrm{~N}_{2} \mathrm{O}_{5} \mathrm{~S}$ \\
\hline FW & 612.22 & 654.30 & 717.36 & 570.15 \\
\hline $\mathrm{T}, \mathrm{K}$ & $100(2)$ & $100(2)$ & $100(2)$ & $100(2)$ \\
\hline$\lambda, \AA$ & 0.71073 & 0.71073 & 0.71073 & 0.71073 \\
\hline Crystal system & Monoclinic & Monoclinic & Monoclinic & Orthorhombic \\
\hline Space group & $\mathrm{P} 2_{1} / n$ & $\mathrm{P} 2_{1} / n$ & $\mathrm{C} 2 / \mathrm{c}$ & $\mathrm{Pbca}$ \\
\hline$a, \AA$ & $10.9065(9)$ & $12.081(4)$ & $28.694(3)$ & $15.1677(7)$ \\
\hline$b, \AA$ & $14.8064(11)$ & $17.491(6)$ & $10.6013(9)$ & $13.5839(6)$ \\
\hline$c, \AA$ & $15.9959(12)$ & $13.857(4)$ & $23.210(2)$ & $22.1751(10)$ \\
\hline$\beta$ & $101.382(3)$ & $107.13(2)$ & $116.562(3)$ & 90 \\
\hline Cell Volume, $\AA^{3}$ & $2532.3(3)$ & $2798.2(16)$ & $6315.0(10)$ & $4568.9(4)$ \\
\hline $\mathrm{Z}$ & 4 & 4 & 8 & 8 \\
\hline$D_{c}, \mathrm{~g} \cdot \mathrm{cm}^{-3}$ & 1.606 & 1.553 & 1.509 & 1.658 \\
\hline$\mu, \mathrm{mm}^{-1}$ & 1.287 & 1.170 & 1.046 & 1.420 \\
\hline $\mathrm{F}(000)$ & 1256 & 1352 & 2960 & 2320 \\
\hline Crystal size, $\mathrm{mm}$ & $0.16 \times 0.14 \times 0.11$ & $0.22 \times 0.20 \times 0.10$ & $0.18 \times 0.16 \times 0.12$ & $0.18 \times 0.16 \times 0.11$ \\
\hline$\theta$ limits & $1.892-25.027$ & $1.929-27.000$ & $1.962-26.000$ & $1.837-25.999$ \\
\hline Reflections collected & 44,496 & 37,875 & 39,670 & 59,100 \\
\hline Independent reflections & $4453\left[R_{\text {int }}=0.1492\right]$ & $6110\left[R_{\text {int }}=0.0453\right]$ & $6200\left[R_{\text {int }}=0.0435\right]$ & $4467\left[R_{\text {int }}=0.0805\right]$ \\
\hline Data/restraints/parameters & $4453 / 0 / 328$ & $6110 / 24 / 356$ & $6200 / 175 / 454$ & $4467 / 0 / 300$ \\
\hline Goodness on fit on $\mathrm{F}^{2}$ & 1.054 & 1.127 & 1.084 & 1.252 \\
\hline$R_{1}(I>2 \sigma(I))$ & 0.0597 & 0.0485 & 0.0581 & 0.0532 \\
\hline$w R_{2}$ (all data) & 0.1606 & 0.1056 & 0.16030 & 0.1085 \\
\hline Largest diff. peak and hole, e $\AA^{-3}$ & $0.966 /-0.694$ & $0.830 /-0.579$ & $2.211 /-0.881$ & $0.803 /-0.469$ \\
\hline
\end{tabular}

\subsection{DFT Calculations}

All geometries were optimized with ORCA 4.0.1.2 [80], using the BP86 functional in conjunction with a triple- $\zeta$ quality basis set (def2-TZVP). The dispersion corrections were introduced using the Grimme D3-parametrized correction and the Becke Johnson damping to the DFT energy [81]. Relativistic effects were treated with the scalar zeroth-order regular 
approximation (ZORA) [82,83], in conjunction with SARC/J auxiliary basis sets. Most of the structures were confirmed to be local energy minima (no imaginary frequencies), but in some cases a small, unavoidable negative frequency relative to the $\mathrm{Cp}$ rotation around the M-Cp axis was observed.

Energy Decomposition Analysis [84]. The EDA has been performed using ORCA 4.1.0. The EDA allows the decomposition of the bond energy into physically meaningful contributions. The interaction energy $\left(\mathrm{E}_{\text {int }}\right)$ is the difference of the energy between the adduct and the unrelaxed fragments. It can be divided into contributions associated with the orbital, steric, and dispersion interactions, as shown in Equation (1).

$$
E_{\text {int }}=E_{s t}+E_{\text {orb }}+E_{\text {disp }}
$$

$E_{s t}$ is usually called the steric interaction energy and it is the sum of $E_{\text {elst }}$, the classical electrostatic interaction between the unperturbed charge distributions of the fragments $\left(\rho_{\mathrm{A}}\right.$ and $\left.\rho_{\mathrm{B}}\right)$ at their final positions in the adduct, and the Pauli repulsion $\left(E_{\text {Pauli }}\right)$, that is the energy change associated with going from $\rho_{A}+\rho_{B}$ to the antisymmetrized and renormalized wave function. The decomposition of $\mathrm{E}_{\mathrm{st}}$ is not possible with ORCA 4.1.0, and it comprises the destabilizing interactions between the occupied orbitals; and, it is responsible for any steric repulsion. $E_{o r b}$ is the contribution arising from allowing the wave function to relax to the fully converged one, accounting for electron pair bonding, charge transfer and polarization, while $\mathrm{E}_{\mathrm{disp}}$ is the contribution of the dispersion forces.

Extended Transition State-Natural Orbital for Chemical Valence theory (ETSNOCV) and Charge Displacement Function Analysis [85,86]. In the NOCV approach, the electron density rearrangement that takes place upon formation of $A B$ from fragments $\mathrm{A}$ and $\mathrm{B}$ is defined with respect to a reference system made up of the occupied $\psi_{i}{ }^{A}$ and $\psi_{i}{ }^{B}$ orbitals of $A$ and $B$ orthonormalized with respect to each other $\left(\psi_{i}{ }^{0}\right)$. In other words, rather than two separate A and B determinants, their antisymmetrized product is taken as the fragment-fragment noninteracting reference (the so-called "promolecule"). The resulting electron density rearrangement in Equation (2),

$$
\Delta \rho_{\text {tot }}=\sum_{i}\left|\psi_{i}^{A B}\right|^{2}-\left|\psi_{i}^{0}\right|^{2}
$$

where $\psi_{i}{ }^{A B}$ is the set of occupied orbitals of the adduct, can be brought into a diagonal form in terms of NOCVs.

These are defined as the eigenfunctions, $\phi_{ \pm k}$, of the so-called "valence operator" Equation (3) [87-89].

$$
\hat{V}=\sum_{i}\left(\left|\psi_{i}^{(A B)}\right\rangle\left\langle\psi_{i}^{(A B)}|-| \psi_{i}^{0}\right\rangle\left\langle\psi_{i}^{0}\right|\right)
$$

The NOCVs can be grouped in pairs of complementary orbitals $\left(\phi_{k}, \phi_{-k}\right)$ corresponding to eigenvalues with the same absolute value but the opposite sign (Equation (4)).

$$
\hat{V} \varphi_{ \pm k}= \pm v_{k} \varphi_{ \pm k}\left(v_{k}>0\right)
$$

where $k$ numbers the NOCV pairs ( $k=0$ for the largest value of $v_{k}$ ).

In this framework, $\Delta \rho^{\prime}$ can be defined as in Equation (5).

$$
\Delta \rho^{\prime}=\sum_{k} v_{k}\left(\left|\varphi_{k}\right|^{2}-\left|\varphi_{-k}\right|^{2}\right)=\sum_{k} \Delta \rho_{k}^{\prime}
$$

Hence, on formation of $\mathrm{AB}$ from the promolecule, a fraction $v_{k}$ of electrons is transferred from the $\phi_{-k}$ to the $\phi_{k}$ orbital. Only some NOCV pairs have $\boldsymbol{v}_{k}$ significantly different from zero, and this subgroup is generally enough to describe the A $\cdots B$ interaction. For each value of $k$, an energy contribution associated with the $k$-th NOCV pair is given $\left(E_{k}\right)$. 
The charge displacement function analysis $[90,91]$ is based on Equation (6) on the relevant $\Delta \rho^{\prime}{ }_{k}$ functions. The function $\Delta q\left(z^{\prime}\right)$ defines, at each point along a chosen axis, the amount of electron charge that, upon formation of the bond between the fragments, moves across a plane perpendicular to the axis through the point $z^{\prime}$. A positive (negative) value corresponds to electrons flowing in the direction of decreasing (increasing) z. Charge accumulates where the slope of $\Delta \boldsymbol{q}$ is positive and decreases where it is negative.

$$
\Delta q_{k}(z \prime)=\int_{-\infty}^{+\infty} d x \int_{-\infty}^{+\infty} d y \int_{-\infty}^{z \prime} d z \Delta \rho_{k}
$$

To extract a CT value from the $\Delta \boldsymbol{q}$ curve, it is useful to fix a plausible boundary separating the fragments in the adducts (isoboundary). Unless otherwise specified, we chose the point on the $z$ axis at which equal-valued isodensity surfaces of the isolated fragments are tangent. At this point, the value of $\Delta q_{k}$ is represented by $\mathrm{CT}_{\mathrm{k}}$.

Supplementary Materials: The following are available online: NMR spectra (Figures S1-S25); IR spectra (Figures S26-S47); isodensity surface plots (Figure S48); view of DFT optimized structures (Figures S49-S50); DFT data. CCDC reference numbers $2088526\left((2) \mathrm{CF}_{3} \mathrm{SO}_{3}\right), 2088527\left((3) \mathrm{CF}_{3} \mathrm{SO}_{3}\right)$, $2088528\left((5) \mathrm{CF}_{3} \mathrm{SO}_{3}\right)$ and $2088529\left((11) \mathrm{CF}_{3} \mathrm{SO}_{3}\right)$ contain the supplementary crystallographic data for the X-ray studies reported in this paper. These data can be obtained free of charge at www.ccdc.cam. ac.uk/conts/retrieving.html (or from the Cambridge Crystallographic Data Centre, 12, Union Road, Cambridge CB2 1EZ, UK; fax: (internat.) +44-1223/336-033; e-mail: deposit@ccdc.cam.ac.uk).

Author Contributions: Conceptualization, G.B., L.B., G.P., S.Z., G.C. and F.M.; methodology, G.B., L.B., G.P., S.Z., G.C. and F.M.; software, G.C.; investigation, G.B., L.B., G.P., S.Z., G.C. and F.M.; data curation, G.B., L.B., G.P., S.Z., G.C. and F.M.; writing-original draft preparation, F.M. and G.C.; writing - review and editing, F.M. and G.C.; supervision, F.M. and G.P.; funding acquisition, L.B., G.P., S.Z., G.C. and F.M. All authors have read and agreed to the published version of the manuscript.

Funding: This research was funded by University of Pisa (Fondi di Ateneo 2020).

Institutional Review Board Statement: Not applicable.

Data Availability Statement: Not applicable.

Acknowledgments: Not applicable.

Conflicts of Interest: The authors declare no conflict of interest.

Sample Availability: Samples of the complexes reported in this paper are available from the authors.

\section{References}

1. Storhoff, B.N.; Lewis, H.C., Jr. Organonitrile complexes of transition metals. Coord. Chem. Rev. 1977, 23, 1-29. [CrossRef]

2. Pombeiro, A.J.L.; Kukushkin, V.Y. Comprehensive Coordination Chemistry II; McCleverty, J.A., Meyer, T.J., Eds.; Elsevier: Oxford, UK, 2004; Volume 1, pp. 639-660.

3. Luzyanin, K.Y.; Kuznetsov, M.L. Advances in Organometallic Chemistry and Catalysis; Pombeiro, A.J.L., Ed.; Wiley: Hoboken, NJ, USA, 2014; pp. 171-183.

4. Rach, S.F.; Kühn, F.E. Nitrile Ligated Transition Metal Complexes with Weakly Coordinating Counteranions and Their Catalytic Applications. Chem. Rev. 2009, 109, 2061-2080. [CrossRef]

5. Pullen, E.E.; Rabinovich, D.; Incarvito, C.D.; Concolino, T.E.; Rheingold, A.L. Syntheses and Structures of Methyltris(pyrazolyl)silane Complexes of the Group 6 Metals. Inorg. Chem. 2000, 39, 1561-1567. [CrossRef] [PubMed]

6. Wang, R.; Zheng, Z. Dendrimers Supported by the $\left[\operatorname{Re}_{6} \mathrm{Se}_{8}\right]^{2+}$ Metal Cluster Core. J. Am. Chem. Soc. 1999, 121, 3549-3550. [CrossRef]

7. Fogg, D.E.; James, B.R. Chiral and Achiral Diphosphine Complexes of Ruthenium(II) Incorporating Labile Nitrile Ligands: Synthesis and Solution Chemistry of Mono- and Dinuclear Derivatives of $\mathrm{Ru}_{2} \mathrm{Cl}_{4}(\mathrm{PP})_{2}(\mathrm{PP}=\mathrm{Chelating}$ Diphosphine). Inorg. Chem. 1997, 36, 1961-1966. [CrossRef]

8. Huang, X.; Meggers, E. Asymmetric photocatalysis with bis-cyclometalated rhodium complexes. Acc. Chem. Res. 2019, 52, 833-847. [CrossRef]

9. You, D.; Yang, H.; Sen, S.; Gabbai, F.P. Modulating the $\sigma$-Accepting Properties of an Antimony Z-type Ligand via Anion Abstraction: Remote-Controlled Reactivity of the Coordinated Platinum Atom. J. Am. Chem. Soc. 2018, 140, 9644-9651. [CrossRef] 
10. Benedikter, M.J.; Musso, J.V.; Frey, W.; Schowner, R.; Buchmeiser, M.R. Cationic Group VI Metal Imido Alkylidene N-Heterocyclic Carbene Nitrile Complexes: Bench-Stable, Functional-Group-Tolerant Olefin Metathesis Catalysts. Angew. Chem. Int. Ed. 2021, 60, 1374-1382. [CrossRef]

11. Woodman, T.J.; Thornton-Pett, M.; Hughes, D.L.; Bochmann, $\mathrm{M} . \mathrm{B}\left(\mathrm{C}_{6} \mathrm{~F}_{5}\right)_{3}$ as $\mathrm{C}_{6} \mathrm{~F}_{5}$ Transfer Agent in Zirconium Chemistry: Borole Sandwich and Borole-Bridged Triple-Decker Complexes. Organometallics 2001, 20, 4080-4091. [CrossRef]

12. Michelin, R.A.; Mozzon, M.; Bertani, R. Reactions of transition metal-coordinated nitriles. Coord. Chem. Rev. 1996, 147, 299-338. [CrossRef]

13. Viguri, M.E.; Huertos, M.A.; Perez, J.; Riera, L. Imidazole-nitrile or imidazole-isonitrile C-C coupling on rhenium tricarbonyl complexes. Chem. Eur. J. 2013, 19, 12974-12977. [CrossRef]

14. Chernyshev, A.N.; Bokach, N.A.; Gushchin, P.V.; Haukka, M.; Kukushkin, V.Y. Reactions of platinum (IV)-bound nitriles with isomeric nitroanilines: Addition vs. substitution. Dalton Trans. 2012, 41, 12857-12864. [CrossRef]

15. Gonzalez-Fernandez, R.; Crochet, P.; Cadierno, V. Arene-ruthenium(II) and osmium(II) complexes as catalysts for nitrilehydration and aldoxime rearrangement reactions. Inorg. Chim. Acta 2020, 517, 120180.

16. Eniko Czégéni, C.; De, S.; Udvardy, A.; Derzsi, N.J.; Papp, G.; Papp, G.; Joó, F. Selective Hydration of Nitriles to Corresponding Amides in Air with Rh(I)-N-Heterocyclic Complex Catalysts. Catalysts 2020, 10, 125. [CrossRef]

17. Xing, X.; Xu, C.; Chen, B.; Li, C.; Virgil, S.C.; Grubbs, R.H. Highly Active Platinum Catalysts for Nitrile and Cyanohydrin Hydration: Catalyst Design and Ligand Screening via High-Throughput Techniques. J. Am. Chem. Soc. 2018, 140, 17782-17789. [CrossRef] [PubMed]

18. Liu, Y.; Yang, K.; Ge, H. Palladium-catalyzed ligand-promoted site-selective cyanomethylation of unactivated C(sp3)-H bonds with acetonitrile. Chem. Sci. 2016, 7, 2804-2808. [CrossRef]

19. Lee, K.-F.; Yang, T.; Tsang, L.-Y.; Sung, H.H.Y.; Williams, I.D.; Lin, Z.; Jia, G. Azavinylidene Complexes from Coupling Reactions of Organonitriles with Phosphines. Organometallics 2021, 40, 358-369. [CrossRef]

20. Rahman, M.M.; Smith, M.D.; Peryshkov, D.V. Imido Group Interchange in Reactions of Zwitterionic Tantalum(V) Vinylimido Complexes and Nitriles. Organometallics 2018, 37, 2945-2949. [CrossRef]

21. Becker, L.; Arndt, P.; Jiao, H.; Spannenberg, A.; Rosenthal, U. Nitrile-Nitrile C-C Coupling at Group 4 Metallocenes to Form 1-Metalla-2,5-diaza-cyclopenta-2,4-dienes: Synthesis and Reactivity. Angew. Chem. Int. Ed. 2013, 52, 11396-11400. [CrossRef] [PubMed]

22. Alias, F.M.; Daff, P.J.; Paneque, M.; Poveda, M.L.; Carmona, E.; Perez, P.J.; Salazar, V.; Alvarado, Y.; Atencio, R.; Sanchez-Delgado, R. C-C bond-forming reactions of Ir ${ }^{\mathrm{III}}$-alkenyls and nitriles or aldehydes: Generation of reactive hydride- and alkyl-alkylidene compounds and observation of a reversible 1,2-H shift in stable hydride- $\mathrm{Ir}^{\mathrm{III}}$ alkylidene complexes. Chem. Eur. J. 2002, 8 , 5132-5146. [CrossRef]

23. Braunstein, P.; Matt, D.; Dusausoy, Y.; Fischer, J. Complexes of functional phosphines. 6. Five-membered palladium or platinum metallacycles resulting from nucleophilic attack of $\alpha$-phosphino carbanions on organonitriles. Synthesis and crystal structure of [cyclo] trans-Pt $\left[\mathrm{Ph}_{2} \mathrm{PC}\left(\mathrm{COOC}_{2} \mathrm{H}_{5}\right) \mathrm{C}(\mathrm{Ph}) \mathrm{NH}\right]_{2}$ and $\left[\right.$ cyclo] $\mathrm{Pd}(\mathrm{C}-\mathrm{N}) \mathrm{Cl}\left[. \mathrm{mu}^{-}-\mathrm{Ph}_{2} \mathrm{PCH} 2 \mathrm{C}(\mathrm{NH}) \mathrm{C}(\mathrm{CN}) \mathrm{PPh} 2\right] \mathrm{Pd}(\mathrm{C}-\mathrm{N})[(\mathrm{C}-\mathrm{N})=$ $\left.\left(\mathrm{o}-\mathrm{C}_{6} \mathrm{H}_{4} \mathrm{CH}_{2} \mathrm{~N}\left(\mathrm{CH}_{3}\right)_{2}\right)\right]$. Organometallics 1983, 2, 1410-1417.

24. Drago, R.S.J. An analysis of cobaloxime chemistry with the electrostatic-covalent model. Organomet. Chem. 1996, 512, 61-68. [CrossRef]

25. Beech, G.; Marr, G.; Ashcroft, S.J. Thermochemistry of some acetonitrile and benzonitrile complexes of transition-metal halides. J. Chem. Soc. A 1970, 17, 2903-2906. [CrossRef]

26. Pombeiro, A.J.L.; Kukushkin, V.Y. Reactivity of Coordinated Nitriles. In Comprehensive Organometallic Chemistry II; Elsevier: Amsterdam, The Netherlands, 1987; Volume 1.

27. Kuznetsov, M.L.; Pombeiro, A.J.L. Theoretical study of redox induced isomerizations, structure and bonding of nitrile, isocyanide and carbonyl complexes of rhenium. Dalton Trans. 2003, 738-747. [CrossRef]

28. Pombeiro, A.J.L. Electron-donor/acceptor properties of carbynes, carbenes, vinylidenes, allenylidenes and alkynyls as measured by electrochemical ligand parameters. J. Organomet. Chem. 2005, 690, 6021-6040. [CrossRef]

29. Cordiner, R.L.; Albesa-Jove', D.; Roberts, R.L.; Farmer, J.D.; Puschmann, H.; Corcoran, D.; Goeta, A.E.; Howard, J.A.K.; Low, P.J Syntheses and molecular structures of group 8 benzonitrile complexes. J. Organomet. Chem. 2005, 690, 4908-4919. [CrossRef]

30. Clarke, R.E.; Ford, P.C. Benzonitrile and Acetonitrile Complexes of Ruthenium Ammines. Inorg. Chem. 1970, 9, 227-235. [CrossRef]

31. Eagle, C.T.; Farrar, D.G.; Holder, G.N.; Pennington, W.T.; Bailey, R.D. Structural and electronic properties of (2,2-trans)dirhodium(II) tetrakis(N-phenylacetamidate). J. Organomet. Chem. 2000, 596, 90-94. [CrossRef]

32. Garcia, M.H.; Rodrigues, J.C.; Dias, A.R.; Piedade, M.F.M.; Duarte, M.T.; Robalo, M.P.; Lopes, N. Second harmonic generation of १5-monocyclopentadienyl ruthenium p-benzonitrile derivatives by Kurtz powder technique. Crystal and molecular structure determinations of $\left[\mathrm{Ru}\left(\eta^{5}-\mathrm{C}_{5} \mathrm{H}_{5}\right)((+)-\mathrm{DIOP})\left(\mathrm{p}-\mathrm{NCC}_{6} \mathrm{H}_{4} \mathrm{NO}_{2}\right)\right][\mathrm{X}], \mathrm{X}=\mathrm{PF}_{6}{ }^{-}, \mathrm{CF}_{3} \mathrm{SO}_{3}{ }^{-}$and $\left[\mathrm{Ru}\left(\eta^{5}-\mathrm{C}_{5} \mathrm{H}_{5}\right)((+)-\mathrm{DIOP})\left(\mathrm{NCCH}_{3}\right)\right]\left[\mathrm{PF}_{6}\right]$. J. Organomet. Chem. 2001, 632, 133-144.

33. Fernandes Alves, J.J.; Franco, D.W. Acrylonitrile and cyanoacetic acid complexes of Ru(III) and Ru(II) amines: An analysis of the $\sigma$ - and $\pi$-component relevance in the Ru(II)-NCR bond. Polyhedron 1996, 15, 3299-3307. [CrossRef]

34. George, A.V.; Field, L.D.; Malouf, E.Y.; McQueen, E.D.; Pike, S.R.; Purches, G.R.; Hambley, T.W.; Buys, I.E.; White, A.H.; Hockless, D.C.R.; et al. Synthesis and characterisation of nitrile complexes of iron. J. Organomet. Chem. 1997, 538, 101-110. [CrossRef] 
35. Winter, R.F.; Scheiring, T. Synthesis, Structures, Ligand Substitution Reactions, and Electrochemistry of the Nitrile Complexes cis- $\left[\mathrm{Ru}(\mathrm{dppm})_{2} \mathrm{CI}(\mathrm{NCR})\right]^{+} \mathrm{PF}_{6}{ }^{-}\left(\mathrm{dppm}=\mathrm{Bis}\right.$ (diphenylphosphino )methane, $\left.\mathrm{R}=\mathrm{CH}_{3}, \mathrm{C}_{2} \mathrm{H}_{5},{ }^{\mathrm{t}} \mathrm{Bu}, \mathrm{Ph}\right)$. Zeitschrift für Anorganische und Allgemeine Chemie 2000, 626, 1196-1204. [CrossRef]

36. Pilon, A.; Brás, A.R.; Côrte-Real, L.; Avecilla, F.; Costa, P.J.; Preto, A.; Garcia, M.H.; Valente, A. A New Family of Iron(II)Cyclopentadienyl Compounds Shows Strong Activity against Colorectal and Triple Negative Breast Cancer Cells. Molecules 2020, 25, 1592. [CrossRef] [PubMed]

37. Brunner, H.; Tsuno, T.; Kurosawa, T.; Kitamura, H.; Ike, H. Kinetic and Thermodynamic Control of Nitrile Dissociation in the Complexes $\left(\mathrm{R}_{\mathrm{Fe}}, \mathrm{R}_{\mathrm{C}}\right) /\left(\mathrm{S}_{\mathrm{Fe}}, \mathrm{R}_{\mathrm{C}}\right)-\left[\mathrm{CpFe}\left(\right.\right.$ Prophos)NCR]X $\left(\mathrm{X}=\mathrm{I}, \mathrm{PF}_{6}\right)$ by the Inductive Effect. Organometallics 2018, 37, 1892-1899. [CrossRef]

38. Casella, G.; Fonseca Guerra, C.; Carlotto, S.; Sgarbossa, P.; Bertani, R.; Casarin, M. New Light on an Old Debate: Does the $\mathrm{RCN}-\mathrm{PtCl}_{2}$ Bond Include any Back-Donation? $\mathrm{RCN}-\mathrm{PtCl}_{2}$ Backbonding vs the IR $\vee \mathrm{C} \equiv \mathrm{N}$ Blue-shift Dichotomy in Organonitrilesplatinum(II) Complexes. A thorough Density Functional Theory-Energy Decomposition Analysis study. Dalton Trans. 2019, 48, 12974-12985. [CrossRef]

39. Wadepohl, H.; Arnold, U.; Pritzkow, H.; Calhorda, M.J.; Veiros, L.F. Interplay of ketenyl and nitrile ligands on d 6-transition metal centres. Acetonitrile as an end-on (two-electron) and a side-on (four-electron) ligand. J. Organomet. Chem. 1999, 587, 233-243. [CrossRef]

40. Li, G.; Liu, L.; Wang, J.; Li, Q.-s.; Xie, Y.; King, R.B. Juxtaposition of the strong back-bonding carbonyl ligand and weak back-bonding acetonitrile ligand in binuclear iron complexes. Trans. Met. Chem. 2013, 38, 617-625. [CrossRef]

41. Mrozek, M.F.; Wasileski, S.A.; Weaver, M.J. Periodic Trends in Electrode-Chemisorbate Bonding: Benzonitrile on Platinum-Group and Other Noble Metals as Probed by Surface-Enhanced Raman Spectroscopy Combined with Density Functional Theory. J. Am. Chem. Soc. 2001, 123, 12817-12825. [CrossRef]

42. Marchetti, F. Constructing Organometallic Architectures from Aminoalkylidyne Diiron Complexes. Eur. J. Inorg. Chem. 2018, 3987-4003. [CrossRef]

43. Biancalana, L.; De Franco, M.; Ciancaleoni, G.; Zacchini, S.; Pampaloni, G.; Gandin, V.; Marchetti, F. Easily Available and Amphiphilic Diiron Cyclopentadienyl Complexes Exhibit In Vitro Anticancer Activity in 2D and 3D Human Cancer Cells via Redox Modulation Triggered by CO Release. Chem. Eur. J. 2021, 27, 10169-10185. [CrossRef]

44. Marchetti, F.; Zacchini, S.; Zanotti, V. Carbon monoxide-isocyanide coupling promoted by acetylide addition to a diiron complex. Chem. Commun. 2015, 51, 8101-8104. [CrossRef]

45. Albano, V.G.; Busetto, L.; Marchetti, F.; Monari, M.; Zanotti, V. Acetonitrile activation in di-iron-carbyne complexes: Synthesis and structure of the cyanomethyl complex $\left[\mathrm{Fe}_{2}(\mu-\mathrm{CNMe} 2)(\mu-\mathrm{CO})(\mathrm{CO})\left(\mathrm{CH}_{2} \mathrm{CN}\right)(\mathrm{Cp})_{2}\right]$. J. Organomet. Chem. 2002, 649, 64-69. [CrossRef]

46. Albano, V.G.; Bordoni, S.; Busetto, L.; Marchetti, F.; Monari, M.; Zanotti, V. C-N coupling between $\mu$-aminocarbyne and nitrile ligands promoted by tolylacetylide addition to $\left[\mathrm{Fe}_{2}\{\mu-\mathrm{CN}(\mathrm{Me})(\mathrm{Xyl})\}(\mu-\mathrm{CO})(\mathrm{CO})\left(\mathrm{NCCMe}_{3}\right)(\mathrm{Cp})_{2}\right]\left[\mathrm{SO}_{3} \mathrm{CF}_{3}\right]$ : Formation of a novel bridging allene-diaminocarbene ligand. J. Organomet. Chem. 2003, 684, 37-43. [CrossRef]

47. Busetto, L.; Marchetti, F.; Zacchini, S.; Zanotti, V.; Zoli, E. Nitrile ligands activation in dinuclear aminocarbyne complexes. J. Organomet. Chem. 2005, 690, 1959-1970. [CrossRef]

48. Busetto, L.; Marchetti, F.; Zacchini, S.; Zanotti, V. Reactions of Diiron $\mu$-Aminocarbyne Complexes Containing Nitrile Ligands. J. Braz. Chem. Soc. 2003, 14, 902-907. [CrossRef]

49. IR Data for Free Nitriles, $\tilde{u}(\mathrm{~N} \equiv \mathrm{C}) / \mathrm{cm}^{-1}$. Solid Samples: $\mathrm{N} \equiv \mathrm{CPh}, 2229 ; \mathrm{N} \equiv \mathrm{CC}_{6} \mathrm{H}_{4} \mathrm{NMe}_{2}, 2210 ; \mathrm{N} \equiv \mathrm{CC}_{6} \mathrm{H}_{4} \mathrm{NO}_{2}, 2233 ; \mathrm{N} \equiv \mathrm{CC}_{6} \mathrm{H}_{4} \mathrm{~F}$, 2234. Liquid samples: $\mathrm{N} \equiv \mathrm{CMe}, 2253 ; \mathrm{N} \equiv \mathrm{CCMe}_{3}$, 2235. Dichloromethane solutions: $\mathrm{N} \equiv \mathrm{CPh}, 2230 ; \mathrm{N} \mathrm{CC}_{6} \mathrm{H}_{4} \mathrm{NMe}_{2}, 2215$; $\mathrm{N} \equiv \mathrm{CC}_{6} \mathrm{H}_{4} \mathrm{NO}_{2}, 2237 ; \mathrm{N} \equiv \mathrm{CC}_{6} \mathrm{H}_{4} \mathrm{~F}, 2233 ; \mathrm{N} \equiv \mathrm{CMe}, 2254 ; \mathrm{N} \equiv \mathrm{CCMe}_{3}, 2233$.

50. ${ }^{13} \mathrm{C}$ NMR Data for Free Nitriles in Acetone- $\mathrm{d}_{6}$ Solution: $\delta(\mathrm{N} \equiv \mathrm{C}) / \mathrm{ppm}=117.4(\mathrm{~N} \equiv \mathrm{CMe}) ; 126.7(\mathrm{~N} \equiv \mathrm{CCMe}) ; 119.3(\mathrm{~N} \equiv \mathrm{CPh})$; $121.0\left(\mathrm{~N} \equiv \mathrm{CC}_{6} \mathrm{H}_{4} \mathrm{NMe}_{2}\right) ; 117.8\left(\mathrm{~N} \equiv \mathrm{CC}_{6} \mathrm{H}_{4} \mathrm{NO}_{2}\right) ; 118.6\left(\mathrm{~N} \equiv \mathrm{CC}_{6} \mathrm{H}_{4} \mathrm{~F}\right)$.

51. Cox, G.; Dowling, C.; Manning, A.R.; McArdle, P.; Cunningham, D.J. A reinvestigation of the reaction of $\left[\mathrm{Fe}_{2}(\eta-\right.$ $\left.\mathrm{C}_{5} \mathrm{H}_{5}\right)_{2}(\mathrm{CO})_{4-\mathrm{n}}(\mathrm{CNR})_{\mathrm{n}}$ ] ( $\mathrm{n}=1$ or 2$)$ with strong alkylating agents. Organomet. Chem. 1992, 438, 143-158. [CrossRef]

52. Albano, V.G.; Busetto, L.; Castellari, C.; Monari, M.; Palazzi, A.; Zanotti, V. Electrophilically promoted cyanide abstraction in diiron cyano(amino) alkylidene complexes: Molecular structure of $\left[\mathrm{Fe}_{2}(\mathrm{CO})_{2}\left(\eta-\mathrm{C}_{5} \mathrm{H}_{5}\right)_{2}(\mu-\mathrm{CO})\left\{\mu-\mathrm{CN}\left(\mathrm{CH}_{2}\right)_{4} \mathrm{CH} \mathrm{H}_{2}\right\}\right]\left[(\mathrm{OC})_{5} \mathrm{WCNW}(\mathrm{CO})_{5}\right]$. J. Chem. Soc. Dalton Trans. 1993, 3661-3666. [CrossRef]

53. Busetto, L.; Marchetti, F.; Zacchini, S.; Zanotti, V. Diiron and diruthenium aminocarbyne complexes containing pseudohalides: Stereochemistry and reactivity. Inorg. Chim. Acta 2005, 358, 1204-1216. [CrossRef]

54. Albano, V.G.; Busetto, L.; Marchetti, F.; Monari, M.; Zacchini, S.; Zanotti, V. Synthesis and Characterization of New Diiron and Diruthenium $\mu$-Aminocarbyne Complexes Containing Terminal S-, P- and C-Ligands. Zeitschrift für Naturforschung B 2007, 62b, 427-438. [CrossRef]

55. Agonigi, G.; Bortoluzzi, M.; Marchetti, F.; Pampaloni, G.; Zacchini, S.; Zanotti, V. Regioselective Nucleophilic Additions to Diiron Carbonyl Complexes Containing a Bridging Aminocarbyne Ligand: A Synthetic, Crystallographic and DFT Study. Eur. J. Inorg. Chem. 2018, 960-971. [CrossRef]

56. Biancalana, L.; Marchetti, F. Aminocarbyne ligands in Organometallic Chemistry. Coord. Chem. Rev. 2021, 449, 214203. [CrossRef]

57. King, R.B.; Murray, R.M.; Davis, R.E.; Ross, P.K. Organonitrogen derivatives of metal carbonyls: XIII. Reactions of dialkylaminotrimethylsilylacetylenes with metal carbonyls. J. Organomet. Chem. 1987, 330, 115-132. [CrossRef] 
58. Boss, K.; Dowling, C.; Manning, A.R.; Cunningham, D.; McArdle, P. The reaction of $\left[\mathrm{Fe}_{2}\left(\eta-\mathrm{C}_{5} \mathrm{H}_{5}\right)_{2}(\mathrm{CO})(\mathrm{CNMe})(\mu-\mathrm{CO})(\mu-\right.$ $\left.\left.\mathrm{CNMe}_{2}\right)\right]+$ and related salts with trifluoromethanesulphonic acid, $\mathrm{HOSO}_{2} \mathrm{CF}_{3}$ : Structure of cis- $\left[\mathrm{Fe}_{2}\left(\eta-\mathrm{C}_{5} \mathrm{H}_{5}\right)_{2}(\mathrm{CO})_{2}(\mu-\mathrm{CNMe})(\mu-\right.$ $\left.\left.\mathrm{CNMe}_{2}\right)\right]\left[\mathrm{BPh}_{4}\right]$. J. Organomet. Chem. 1999, 579, 252-268. [CrossRef]

59. Madec, P.; Muir, K.W.; Petillon, F.Y.; Rumin, R.; Scaon, Y.; Schollhammer, P.; Talarmin, J. Generation of substrate-binding sites by electrochemical reduction of cis-[Fe2(cp)2( $\mu-\mathrm{SMe}) 2(\mathrm{MeCN})(\mathrm{L})] 2+(\mathrm{L}=\mathrm{CO}$ or MeCN). Reactivity of the sites toward CO and tBuNC Crystal structure of $\left[\mathrm{Fe}_{2}(\mathrm{cp})_{2}(\mu-\mathrm{SMe})_{2}(\mathrm{CO})(\mathrm{MeCN})\right]\left[\mathrm{BF}_{4}\right]_{2} \cdot \mathrm{CH}_{2} \mathrm{Cl}_{2}$. J. Chem. Soc. Dalton Trans. 1999, 2371-2384. [CrossRef]

60. Kuckmann, T.; Lerner, H.-W.; Bolte, M. Redetermination of (acetonitrile-[kappa]N)dicarbonyl([eta]5-cyclopentadienyl)iron(II) tetrafluoridoborate. Acta Crystallogr. 2012, 68E, m966.

61. M'thiruaine, C.M.; Friedrich, H.B.; Changamu, E.O.; Bala, M.D. Acetonitriledicarbonyl([eta]5-pentamethylcyclopentadienyl)iron(II) tetrafluoridoborate. Acta Crystallogr. 2011, 67E, m924.

62. Kalman, S.E.; Petit, A.; Brent Gunnoe, T.; Ess, D.H.; Cundari, T.R.; Sabat, M. Facile and Regioselective C-H Bond Activation of Aromatic Substrates by an Fe(II) Complex Involving a Spin-Forbidden Pathway. Organometallics 2013, 32, 1797-1806. [CrossRef]

63. Chen, J.; Szalda, D.J.; Fujita, E.; Creutz, C. Iron(II) and Ruthenium(II) Complexes Containing P, N, and H Ligands: Structure, Spectroscopy, Electrochemistry, and Reactivity. Inorg. Chem. 2010, 49, 9380-9391. [CrossRef] [PubMed]

64. Clegg, J.K.; Cremers, J.; Hogben, A.J.; Breiner, B.; Smulders, M.M.J.; Thoburnad, J.D.; Nitschke, J.R. A stimuli responsive system of self-assembled anion-binding $\mathrm{Fe}_{4} \mathrm{~L}_{6}{ }^{8+}$ cages. Chem. Sci. 2013, 4, 68-76. [CrossRef]

65. Hoffbauer, M.R.; Iluc, V.M. [2+2] Cycloadditions with an Iron Carbene: A Critical Step in Enyne Metathesis. J. Am. Chem. Soc. 2021, 143, 5592-5597. [CrossRef]

66. Heine, A.; Herbst-Irmer, R.; Stalke, D.; Kuhnle, W.; Zachariasse, K.A. Structure and Crystal Packing of 4-Aminobenzonitriles and 4-Amino-3,5-dimethylbenzonitriles at Various Temperatures. Acta Cryst. 1994, B50, 363-373. [CrossRef]

67. Arrigoni, F.; Bertini, L.; De Gioia, L.; Cingolani, A.; Mazzoni, R.; Zanotti, V.; Zampella, G. Mechanistic Insight into Electrocatalytic $\mathrm{H}_{2}$ Production by $\left[\mathrm{Fe}_{2}(\mathrm{CN})\left\{\mu-\mathrm{CN}(\mathrm{Me})_{2}\right\}(\mu-\mathrm{CO})(\mathrm{CO})(\mathrm{Cp})_{2}\right]$ : Effects of Dithiolate Replacement in [FeFe] Hydrogenase Models. Inorg. Chem. 2017, 56, 13852-13864. [CrossRef] [PubMed]

68. Ortel, A.M.; Ritleng, V.; Chetcuti, M.J.; Veiros, L.F. C-H Activation of Acetonitrile at Nickel: Ligand Flip and Conversion of N-Bound Acetonitrile into a C-Bound Cyanomethyl Ligand. J. Am. Chem. Soc. 2010, 132, 13588-13589. [CrossRef] [PubMed]

69. Tanabe, T.; Evans, M.E.; Brennessel, W.W.; Jones, W.D. C-H and C-CN Bond Activation of Acetonitrile and Succinonitrile by [Tp'Rh $\left(\mathrm{PR}_{3}\right)$ ]. Organometallics 2011, 30, 834-843. [CrossRef]

70. Garcia, M.H.; Robalo, M.P.; Teixeira, A.P.S.; Dias, A.R.; Piedade, M.F.M.; Duarte, M.T. Synthesis of new donor/acceptor $\eta^{5}$-cyclopentadienyl and $\eta^{5}$-indenyliron(II) complexes with $\mathrm{p}$-benzonitrile derivatives. Crystal structures of [Fe $\left(\eta^{5}\right.$ $\left.\left.\mathrm{C}_{5} \mathrm{H}_{5}\right)(\mathrm{CO})\left(\mathrm{P}\left(\mathrm{OC}_{6} \mathrm{H}_{5}\right)_{3}\right)\left(\mathrm{p}-\mathrm{NCC}_{6} \mathrm{H}_{4} \mathrm{NO}_{2}\right)\right]\left[\mathrm{BF}_{4}\right] \cdot \mathrm{CH}_{2} \mathrm{Cl}_{2}$ and $\left[\mathrm{Fe}\left(\eta^{5}-\mathrm{C}_{9} \mathrm{H}_{7}\right)(\mathrm{CO})\left(\mathrm{P}_{\left(\mathrm{OC}_{6} \mathrm{H}_{5}\right)}\right)\left(\mathrm{p}-\mathrm{NCC}_{6} \mathrm{H}_{4} \mathrm{NO}_{2}\right)\right]\left[\mathrm{BF}_{4}\right]$. J. Organomet. Chem. 2001, 632, 145-156. [CrossRef]

71. Bengu, B.; Boerio, F.J. Interaction of epoxy/dicyandiamide adhesives with metal substrates. J. Adhes. 2006, 82, 1133-1155. [CrossRef]

72. Bistoni, G.; Rampino, S.; Scafuri, N.; Ciancaleoni, G.; Zuccaccia, D.; Belpassi, L.; Tarantelli, F. How $\pi$ back-donation quantitatively controls the CO stretching response in classical and non-classical metal carbonyl complexes. Chem. Sci. 2016, 7, 1174-1184. [CrossRef]

73. Lupinetti, A.J.; Fau, S.; Frenking, G.; Strauss, S.H. Nonclassical Metal Carbonyls: $[\mathrm{Ag}(\mathrm{CO})]^{+}$and $\left[\mathrm{Ag}(\mathrm{CO})_{2}\right]^{+}$. J. Phys. Chem. A 1997, 101, 9551-9559. [CrossRef]

74. Frenking, G.; Loschen, C.; Krapp, A.; Fau, S.; Strauss, S.H. Electronic structure of CO-An exercise in modern chemical bonding theory. J. Comput. Chem. 2007, 28, 117-126. [CrossRef] [PubMed]

75. Menges, F. Spectragryph—Optical Spectroscopy Software. Version 1.2.5, @2016-2017. Available online: http://www.effemm2.de/ spectragryph (accessed on 1 November 2021).

76. Fulmer, G.R.; Miller, A.J.M.; Sherden, N.H.; Gottlieb, H.E.; Nudelman, A.; Stoltz, B.M.; Bercaw, J.E.; Goldberg, K.I. NMR Chemical Shifts of Trace Impurities: Common Laboratory Solvents, Organics, and Gases in Deuterated Solvents Relevant to the Organometallic Chemist. Organometallics 2010, 29, 2176-2179. [CrossRef]

77. Willker, W.; Leibfritz, D.; Kerssebaum, R.; Bermel, W. Gradient selection in inverse heteronuclear correlation spectroscopy. Magn Reson. Chem. 1993, 31, 287-292. [CrossRef]

78. Sheldrick, G.M. Crystal structure refinement with SHELXL. Acta Crystallogr. C 2015, 71, 3-8. [CrossRef]

79. Spek, A.L. PLATON, A Multipurpose Crystallographic Tool; Utrecht University: Utrecht, The Netherlands, 2005.

80. Neese, F. Software Update: The ORCA Program System, Version 4.0. WIREs Comput. Mol. Sci. 2017, 8, e1327. [CrossRef]

81. Grimme, S.; Antony, J.; Ehrlich, S.; Krieg, H. A consistent and accurate ab initio parametrization of density functional dispersion correction (DFT-D) for the 94 elements H-Pu. J. Chem. Phys. 2010, 132, 154104. [CrossRef] [PubMed]

82. Van Lenthe, E.; Baerends, E.J.; Snijders, J. Relativistic regular two-component Hamiltonian. J. Chem. Phys. 1993, 99, 4597-4610. [CrossRef]

83. Van Lenthe, E.; Ehlers, A.; Baerends, E.-J. Geometry optimizations in the zero order regular approximation for relativistic effects. J. Chem. Phys. 1999, 110, 8943-8953. [CrossRef]

84. Hopffgarten, M.; von Frenking, G. Energy decomposition analysis. WIREs Comput. Mol. Sci. 2012, 2, 43-62. [CrossRef]

85. Mitoraj, M.P.; Michalak, A.; Ziegler, T. A Combined Charge and Energy Decomposition Scheme for Bond Analysis. J. Chem. Theory Comput. 2009, 5, 962-975. [CrossRef]

86. Radoń, M. On the properties of natural orbitals for chemical valence. Theor. Chem. Acc. 2008, 120, 337-339. [CrossRef] 
87. Nalewajski, R.F.; Mrozek, J.; Michalak, A. Two-electron valence indices from the Kohn-Sham orbitals. Int. J. Quantum Chem. 1997, 61, 589-601. [CrossRef]

88. Nalewajski, R.F.; Ozek, J. Modified valence indices from the two-particle density matrix. Int. J. Quantum Chem. 1994, 51, 187-200. [CrossRef]

89. Nalewajski, R.F.; Köster, A.M.; Jug, K. Chemical valence from the two-particle density matrix. Theor. Chim. Acta 1993, 85, 463-484. [CrossRef]

90. Ciancaleoni, G.; Nunzi, F.; Belpassi, L. Charge Displacement Analysis-A Tool to Theoretically Characterize the Charge Transfer Contribution of Halogen Bonds. Molecules 2020, 25, 300. [CrossRef] [PubMed]

91. Bistoni, G.; Rampino, S.; Tarantelli, F.; Belpassi, L. Charge-displacement analysis via natural orbitals for chemical valence: Charge transfer effects in coordination chemistry. J. Chem. Phys. 2015, 142, 084112. [CrossRef] [PubMed] 